REVIEW ARTICLE

\title{
Myxozoan genera: definition and notes on taxonomy, life-cycle terminology and pathogenic species
}

\author{
Jiří Lom and Iva Dyková \\ Institute of Parasitology, Academy of Sciences of the Czech Republic, Branišovská 31, 37005 České Budějovice, Czech \\ Republic
}

Key words: Myxozoa, definition of genera, taxonomy, terminology, phylogeny, pathogenic species

\begin{abstract}
A list of myxozoan genera is presented in the current taxonomical scheme. These genera are defined; their type species and most important pathogens along with their hosts are listed. Simultaneously, definitions of actinospore stages representing sexual stages of the myxosporean life cycle are given; altogether, 17 actinospore collective groups with 180 types have been described. Life cycles of the two classes of the phylum Myxozoa, Malacosporea and Myxosporea, are briefly outlined with specification of the appropriate terms. Up to now, 4 malacosporean and 2,180 myxosporean species assigned to a total of 62 genera, have been established. The surviving classification of myxosporeans, based on spore morphology, is discussed in the context of the still fragmentary data resulting from SSU rDNA sequence analyses. The main task for the future is a rigorous, detailed morphological description combined with molecular techniques in establishment of new species and in revision of the existing ones. Establishment of a classification acceptable from morphological, biological and phylogenetical viewpoints is necessary.
\end{abstract}

Myxozoa enjoy increasing attention not just because new myxosporean pathogens are continually emerging and threatening the development of pisciculture. New findings on life cycles, the discovery of the new class Malacosporea and the dispute on myxosporean phylogeny and origin provide additional stimuli for their study. Although in recent research the experimental approach prevails, descriptions of new myxosporean genera have not fallen behind.

In the first, "discovery decade" 1890 to 1900 , ten genera were established; in the following decades, until 1980 , the number of newly described genera fluctuated between one and five, while in the decade 1980-1990 the number of genera newly established increased to 14, and in 1991-2000 nine new genera were discovered.

Classification of the phylum has a long history since the discovery of Myxosporea by Jurine (1825) and subsequent observation by Müller (1841) and actually began when Otto Bütschli (1882) classified Myxosporida (along with Sarcosporida) as a subclass of the then class Sporozoa. The subsequent twists and turns in classification of this group can be followed in detail in publications by Balbiani (1883), Gurley $(1893,1894)$, Thélohan (1895), Doflein (1898), Štolc (1899), Auerbach (1910), Kudo (1919, 1933), Hartmann (1923-1925), Tripathi (1948), Shulman (1966), Grassé (1960, 1970), Lom and Noble (1984), Donets and Shulman (1984), and Kent et al. (1994a).

A groundbreaking discovery was the recognition that the enigmatic creature Buddenbrockia living within bryozoans was a primitive myxozoan (Canning et al. 1996). After more than one hundred years of alleged protozoan nature and disputes on their possible meta- zoan affinities, Myxozoa were finally transferred to Metazoa. Cavalier-Smith (1998) considers them to be a subkingdom of Animalia; Hausmann et al. (2003) list them as a superclass of infraphylum Metazoa within the phylum Opisthoconta (Empire Eukaryota). The majority of molecular studies (Smothers et al. 1994, Schlegel et al. 1996, Anderson et al. 1998, Okamura et al. 2002, Zrzavý and Hypša 2003) assign Myxozoa to Bilateria or their sister group. The controversial finding of Kelley et al. (2004) that Myxobolus cerebralis branches with its actin gene sequence outside both opisthokonts and Amoebozoa warrants further phylogenetic analysis. The simple body form, especially in Myxosporea, is viewed as the result of large-scale reduction due to adaptation to parasitism. Extensive discussion of the putative processes leading to present-day myxozoan cell structure and equipment with polar capsules can be found in Canning and Okamura (2004).

A short summary of the phylum is in Kent et al. (2000b). The rather recent state is presented in Kent et al. (2001) and the last outline of the framework of the phylum's classification can be found in Canning and Okamura (2004).

In this review we attempt to summarise the present rather neglected state of classification of myxozoan genera and of actinospore stages of Myxosporea. In each genus, we draw attention to the most important pathogenic species currently recognised.

\section{Phylum MyXozoA Grassé, 1970}

Parasites of invertebrates and vertebrates characterised by spores composed of several cells transformed into one to seven spore shell valves, one to many amoe- 
boid infective germs (sporoplasms) and one to several nematocyst-like polar capsules (in Kudoa permulticapsula up to 15). The capsules contain an extrudible filament with an anchoring function. The typically eukaryotic cells lack centrioles and flagella. Mitochondria have tubular, flat or discoid cristae. Cell junctions are commonly found. Vegetative (trophic) stages in the form of a primitive bilateral worm-like organism or in the form of a closed sac (class Malacosporea) have been in most representatives (class Myxosporea) reduced to a spore-producing multicellular, often amoeboid plasmodium.

In the class Myxosporea, vegetative stages may be coelozoic (in body cavities or cavities of body organs) or histozoic, intercellular (wedged between tissue cells), or often intracellular. The life-cycle pattern - supposed to be present in most of the species - involves alternation of hosts, one of them, in which the sexual process has been proven, being the definitive one (an invertebrate), the second (a vertebrate) serving mainly for parasite multiplication. The cell-in-cell organisation is typical of stages in vertebrates.

References: Grassé and Lavette (1978), Uspenskaya (1984), Lom (1990), Siddall et al. (1995), Kent et al. (2000b, 2001).

Class Malacosporea Canning, Curry, Feist, Longshaw et Okamura, 2000

\section{Life cycle, structure and terminology}

Parasites of freshwater bryozoans (Phylum Bryozoa, Class Phylactolaemata). The trophic, proliferative stages live within bryozoan body cavity in the form of closed multicellular sacs or worm-like organisms (also termed vermiform bodies).

Trophic stages are preceded by cryptic stages in the host epithelium - they may persist there for a period of up to six weeks and develop first in loose clusters without cell junctions, then rearrange themselves to form the trophic stages, i.e., simple sac-like or vermiform organisms. The worm-like organism (up to about $3.6 \times 0.1$ $\mathrm{mm}$ ) of Buddenbrockia plumatellae has an outer wall formed by a layer of flat mural cells, bound together by cell junctions. The outer wall encloses four longitudinal muscle blocs and an inner layer of cells. This layer consists of more dense type $\mathbf{B}$ cells separated by larger, less dense - perhaps secretory - type A cells. In more advanced vermiform stages, B cells proliferate and pile up in several layers and then disperse in the lumen of the "worm". These pre-spore cells will become spores after completion of meiosis. Then they divide to form compact groups of ten, which mature as typical spherical malacospores with eight unhardened shell valves topped by four polar capsules, including two sporoplasms with inner (secondary) cells inside them. Sporoplasms have electron-dense bodies with lucent invaginations, sporoplasmosomes. Polar capsules and sporoplasms are encased with valvogenic cells, which in ma- lacospores do not cover the exit point of the polar filament. Polar capsules at the anterior pole of the spore have their mouths covered by a dense cap overlain by a structure of fibrous components. During capsulogenesis, external tube of the capsular primordium is not always observed but has been proven in some populations. In some malacosporean populations spores arise in the layer of mural cells (Morris et al. 2002).

The ellipsoid, sac-like stages or sacs of Tetracapsuloides bryosalmonae are simpler: there is an outer layer of mural cells subtended by an incomplete layer of B cells destined to become spores. Deeper from the wall there is a mass of free cells; a group of distinctive stellate cells aggregate around a sporoplasmogenic cell which undergo meiosis. A spherical malacospore is then produced from this aggregation.

In $T$. bryosalmonae there is a stage infecting salmonid fish, primarily kidney, as the so-called PKX stage, the agent of proliferative kidney disease (PKD). These stages are composed of an enveloping cell with sporoplasmosomes of a special form and contain an inner, secondary cell that in turn may contain tertiary cells. Sporogenesis is mostly missing. However, Hedrick et al. (2004) found mature spores in the urine of Oncorhynchus mykiss, different from bryozoan malacospores, for which the term fishmalacospores was proposed. These spores have two shell valves enclosing two polar capsules and one sporoplasm.

No complete malacosporean life cycle has been unravelled thus far. As Tops et al. (2004) reported, there is no evidence for bryozoan-to-bryozoan transmission and there might be another malacosporean host still unidentified. Transmission of Tetracapsuloides from fish to bryozoans still requires further investigation. Taticchi et al. (2004) suggested that $T$. bryosalmonae might be transmitted within bryozoan statoblasts. T. bryosalmonae is not transported through fisheries activities (Henderson and Okamura 2004).

The genus representing the class, Buddenbrockia, may well be taken for a missing link between bilaterian ancestors and highly derived myxosporeans that have lost all ancestral features.

References: Anderson et al. (1998), Canning et al. (2000, 2002), Monteiro et al. (2002), Okamura et al. (2002), Canning and Okamura (2004), McGurk et al. (2005).

Order Malacovalvulida Canning, Curry, Feist, Longshaw et Okamura, 2000

With characters of the class.

S a c c o s p o r i d a e Canning, Okamura et Curry, 1996

With characters of the order. All uninucleate cells within the sac are potential spores.

Buddenbrockia Schröder, 1910 Fig. 1

Synonym: Tetracapsula Canning, Okamura et Curry, 1996

Trophic stages in form of both sac-like and worm-like organisms of triploblast organisation. Cells produced by division of one sporogonic cell into ten cells are needed to constitute 
the spore (four valvogenic, four capsulogenic and two sporoplasms, each of the latter with one secondary cell inside). Spherical spores have at their anterior pole four polar capsules. Buddenbrockia can probably not be transmitted directly from bryozoan to bryozoan. Vertical transmission occurs by colony fragmentation and further growth of the offspring thus produced.

Type species Buddenbrockia plumatellae Schröder, 1910 (syn. Tetracapsula bryozoides Canning, Okamura et Curry, 1996) described from the coelomic cavity of Plumatella fungosa from Belgium, found later in six other species, is cosmopolitan. Vermiform forms are up to $3.6 \mathrm{~mm}$ long. Spores are spherical, $19 \mu \mathrm{m}$ in size when fresh (Fig. 1). Tops et al. (2005) have announced discovery of two more species.

References: Schröder (1910), Canning et al. (1996).

Tetracapsuloides Canning, Tops, Curry, Wood et Okamura, 2002

Fig. 2

Differs from the preceding in that the trophic stages are in form of a closed sac formed by a simple layer of cells. Spores develop from an aggregate of distinctive stellate cells, probably diploid, around a sporoplasmogenic cell that undergoes meiosis. The $18 \mathrm{~S}$ rDNA sequence differs by $20 \%$ from that of Buddenbrockia (Anderson et al. 1999a).

Tetracapsuloides bryosalmonae (Canning, Curry, Feist, Longshaw et Okamura, 1999) Canning, Tops, Curry, Wood et Okamura, 2002 was first identified from Cristatella mucedo, Pectinatella magnifica and Plumatella rugosa from Ohio and Michigan, USA (Anderson et al. 1999a, b). It also occurs in other bryozoan species (Okamura and Wood 2002, Canning and Okamura 2004). Mature subspherical fishmalacospores with two soft valves, two polar capsules and a single sporoplasm (Fig. 2) were reported from the urine of Oncorhynchus mykiss (Hedrick et al. 2004). Based on development to an immature stage in salmonid fish, Kent et al. (2000a) described the species as Tetracapsula renicola Kent, Khattra, Hedrick et Devlin, 2000, which is a junior synonym of Tetracapsuloides bryosalmonae.

Tetracapsuloides bryosalmonae is the agent ("PKX") of proliferative kidney disease of cultured (and wild) salmonid fishes of the genera Salmo, Oncorhynchus, Thymallus and also pike (Esox) in North America and Europe, sought since the 1970 's.

According to Morris et al. (2000), the portal of entry of infectious sporoplasms are the gills, while Longshaw et al. (2002) found it to be mucous cells in the skin. In renal interstitium of the fish the "PKX" cell complexes appear. Stages proliferating in the interstitium provoke a vigorous defence reaction of the host and hereby the actual disease. Mortality in susceptible fish, especially fry, may fluctuate from 30 to $50 \%$. It has been widely speculated that salmonids are accidental, facultative or dead-end hosts for T. bryosalmonae. Phylogenetic analysis using molecular methods implies that southern Europe was colonised by immigration of the parasite from North America and that this colonisation substantially predated fisheries activities (Henderson and Okamura 2004).

References: Bucke et al. (1991), Hedrick et al. (1993), Canning et al. (1999b), Morris et al. (2000), Okamura et al. (2001), Tops and Okamura (2003).

\section{Class MyXosporea Bütschli, 1881}

\section{Life cycle, structure and terminology}

Following the basic discovery of Wolf and Markiw (1984), it has been accepted that as a rule the life cycle takes place in two hosts. The term myxosporean covers both life-cycle phases, the myxospore and actinospore one. The generally better known myxospore phase, resulting in production of myxospores, takes place in lower vertebrates, typically in fish, rarely in amphibians and reptiles, exceptionally perhaps in birds and mammals. Hosts of the actinospore phase, involving a sexual process and resulting in production of actinospores, are annelids, rarely sipunculids. The myxospores are as a rule hard-shelled, with two (sometimes more) shell valves and are produced in small or large sporogonial plasmodia. A typical feature in developmental stages is the cell-in-cell condition, when the endogenously produced (secondary) cells persist inside the primary (mother) cells. Myxosporea lack centrioles and display a closed mitosis. The microtubules of the spindle often persist as a coherent bundle long after karyokinesis. Mitochondrial cristae are of variable shape, plate-like, tubular or discoid.

The actinospore, discharged from an annelid into water, randomly encounters the fish (intermediate) host. Upon contact with the skin or gill epithelium, polar capsules discharge their polar filaments, fastening the spore to the host. Then the spore shell valves open and the sporoplasm enters the skin generally through the openings of epidermal and epithelial mucous cells. A series of presporogonic stages follows, which may be intraand/or intercellular. They migrate to the site where the sporogonic stage - a plasmodium or a pseudoplasmodium - develops. Both may develop temporary cytoplasmic projections, pseudopodia, and may divide by plasmotomy, i.e., cleavage in two or more daughter parts. Plasmodia can be taken for an extremely reduced sac- or worm-like stage of Malacosporea; their cytoplasm may include a variety of cytoplasmic inclusions. Plasmodial stages may be histozoic, situated in the tissue and often appearing as "cysts", or coelozoic, in cavities of body organs (mainly urinary tract or gall bladder). The plasmodium may be a large body with many vegetative nuclei of its own and with endogenously produced generative cells. These may be of one type, sporogonic cell, each of which produces a spore by division and differentiation, or of two types, sporogonic cell and pericyte. These two latter cells engage in spore formation, sporogony. The pericyte envelops the sporogonic cell which divides into differentiated capsulogenic, valvogenic and sporoplasmogenic cells. Corresponding numbers of these cells develop into two sporoblasts and consequently mature into two myxospores inside the pericyte. Myxospores generally have a hard shell. The pericyte with the progeny of the sporogonic cell represents the pansporoblast. Plasmodia may also enclose lobocytes, large cells of presumably scavenging function within the plasmodium. Large plasmodia produce as a rule many spores, are polysporic. Pseudoplasmodia are rather small, contain one nucleus and generative cells necessary to compose one 


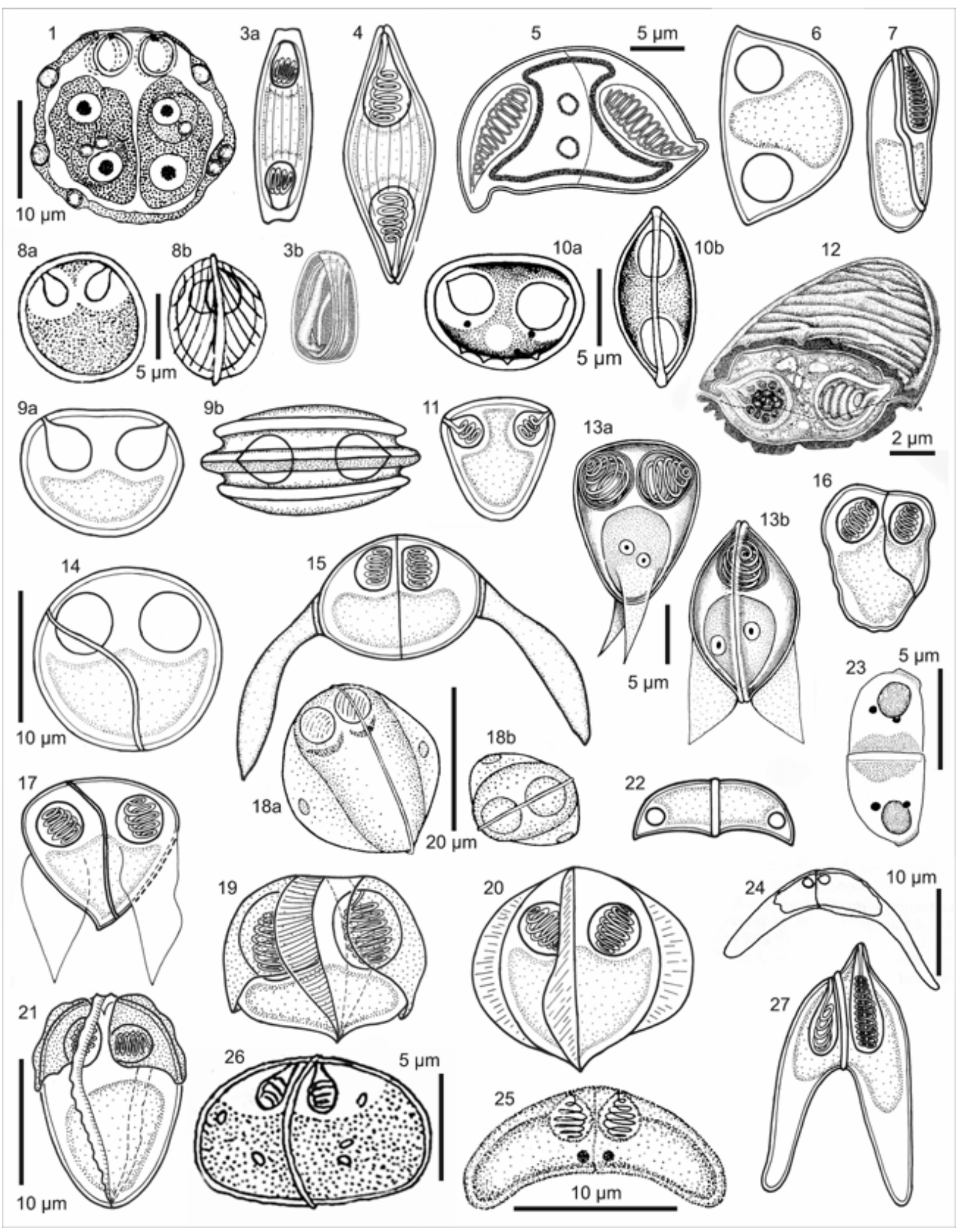

Fig. 1. Malacospore of Buddenbrockia plumatellae; two of the polar capsules are beyond the plane of the drawing; note the two uninucleate sporoplasms, each with a uninucleate secondary cell. Sporoplasms contain sporoplasmosomes (courtesy of Dr. E.U. Canning et al. 1996 and Folia Parasitol.). Figs. 3-27. Line drawings of myxosporean spores. Fig. 3. Sphaeromyxa balbianii in frontal view (a) with polar filament (PF) incorrectly drawn as a spiral (from Thélohan 1895), (b) enlarged polar capsule of 
or two spores (are monosporic or disporic). Sometimes, even when the sporogonic stages have been developed, extrasporogonic stages persist, serving for additional parasite proliferation. The myxospore consists mostly of one to four polar capsules, one or two sporoplasms (the actual infective germs), all these being encased with two to seven shell valves. Capsulogenesis involves regularly production of an external tube associated with the capsular primordium. Shell valves adhere together along the line of dehiscence, the suture line, and also cover the apex of polar capsule. Sporoplasm contains sporoplasmosomes, without the central lucent invagination known in malacosporeans. Under certain conditions, the development in the fish may be arrested before the onset of sporogenesis (Higgins et al. 1993).

When ingested by the definitive host (typically an oligochaete) in which the sexual phase takes place, the sporoplasm of the myxospore initiates a merogony phase. Resulting uninucleate cells produce a tetranucleate stage, two sporogonic cells enveloped by a pair of pericytes, the future pansporocyst. During further development of these cells the two (or more) enveloping cells harbour inside them eight pairs of gametic cells $(\boldsymbol{\alpha}$ and $\boldsymbol{\beta}$ cells) which, having undergone meiosis with the occurrence of synaptonemal complexes, fuse to produce eight zygotes. The zygotes develop by cell division and differentiation into eight triradiate actinospores. In most of these actinospores there is an anterior spore body containing always three polar capsules and three shell valves that leave an opening for the apex of polar capsules, except for sphaeractinomyxon, in which the polar capsules are embedded beneath the surface of the spore. There is, as a rule, a plasmodium-like sporoplasm with many nuclei and many infectious cells. Behind the spore body the shell valves extend in most actinosporean stages into very long, hollow and mutually divergent caudal projections, inflatable osmotically by water into full length when the spore is released from the host. In some actinospore stages, the three projections, prior to diverging from each other, fuse to form a style. The cycle is repeated when the spore encounters a fish host. In a few species, a direct transmission from fish to fish has been proven (e.g., Enteromyxum).
References: life cycle and fine structure - Lom and de Puytorac (1965a, b), Desser and Patterson (1978), Grassé and Lavette (1978), Current (1979), Current et al. (1979), Desportes and Théodorides (1982), Marques (1984), Wolf and Markiw (1984), Lom and Dyková (1988, 1996, 1997), El-Matbouli et al. (1992b, 1995), Kent et al. (1994a, 2001), Lom et al. (1997b), ElMatbouli and Hoffmann (1998).

\section{Hosts}

Most representatives of the myxospore phase live in freshwater and marine fishes; 3 species have been reported in Agnatha, 35 species in Chondrichthyes, and the rest in Osteichthyes. Thirteen myxosporean species have been described from amphibians, and six from reptiles. Nothing has been reported about their possible actinospore phase of the non-fish myxosporeans.

Recently, myxospores or developmental stages resembling those occurring in the fish hosts were also discovered in homeothermic vertebrates. Myxosporeanlike developmental stages, causing xenoma formation, have been found in the brain of a mole (Talpa europaea) in Austria (Friedrich et al. 2000). Developmental stages and unassigned spores were surprisingly found in inflammatory lesions of hepatic ducts in ducks (Lowenstine et al. 2002). There have been also repeated findings of Myxobolus spores in the faeces of humans suffering from intestinal disorders or infected with the HIV virus (e.g., Boreham et al. 1998, Moncada et al. 2001, Hessen and Zamzame 2004). These reports led Canning and Okamura (2004) to postulate that myxozoans may under certain conditions become opportunistic parasites of homeothermic vertebrates.

A few species have been reported to occur in myxospore phase in invertebrates: a Kudoa sp. was found in the muscles of the arm of the giant octopus Paroctopus dofleini (Yokoyama and Masuda 2001). The following are doubtful reports: Chloromyxum diploxys (Gurley, 1893) Thélohan, 1895 was once reported from the abdominal cavity of the lepidopteran Tortrix viridana (Thélohan 1895). It seems to be a myxosporean, but not a Chloromyxum. An alleged myxosporean from an insect, Dactilopius indicus, described as Symmetrula cochinealis Sundara Rajulu et Radha, 1966, is claimed

S. magna Zhukov, 1964 with PF as a broad folded ribbon (from Lom 1969). Fig. 4. Myxidium lieberkuehni. Fig. 5. Enteromyxum scophthalmi (courtesy of Dr. P. Alvarez-Pellitero and Parasitology). Fig. 6. Zschokkella hildae (after Kudo 1919). Fig. 7. Coccomyxa morovi. Fig. 8. Ortholinea divergens in sutural (a) and frontal view (b) with empty polar capsules after the filaments have been extruded (modified from Kudo 1919). Fig. 9. Neomyxobolus ophiocephalus in frontal (a) and apical view (b). Fig. 10. Cardimyxobolus leshanensis in frontal (a) and sutural view (b); modified from Chen and Ma (1998). Fig. 11. Triangula yankiangensis in frontal view. Fig. 12. Triangulamyxa amazonica in oblique partly dissected view (courtesy of Dr. C. Azevedo and Eur. J. Protistol.). Fig. 13. Kentmoseria alata in frontal (a) and sutural view (b) (courtesy of Dr. M.L. Kent and J. Eukaryot. Microbiol.). Fig. 14. Sinuolinea dimorpha (after Kudo 1919). Fig. 15. Davisia diplocrepis. Fig. 16. Myxoproteus abyssus (courtesy of Yoshino and Noble 1974 and J. Parasitol.). Fig. 17. Bipteria admiranda. Fig. 18. Paramyxoproteus reinhardti in sutural (a) and apical view (b) (after Wierzbicka 1986). Fig. 19. Neobipteria macrouri. Fig. 20. Schulmania ovale. Fig. 21. Noblea admiranda. Fig. 22. Fabespora nana. Fig. 23. Fabespora vermicola (courtesy of Dr. R.M. Overstreet and J. Parasitol.). Fig. 24. Ceratomyxa arcuata (from Meglitsch 1960, courtesy of J. Parasitol.). Fig. 25. Ceratomyxa sparusaurati (courtesy of Dr. A. Sitjà-Bobadilla and J. Eukaryot. Microbiol.). Fig. 26. Leptotheca agilis (from Kudo 1919). Fig. 27. Meglitschia insolita. Figs. 3a, $4,6,7,9,11,13,14,15 \mathrm{~b}, 16,18-21,26,29,31-35 \mathrm{a}, \mathrm{b}, 36-38,40-42,45-54,56,58-62$ and 64-67 are taken from Lom and Dyková (1992) with kind permission of Elsevier Publishers. 


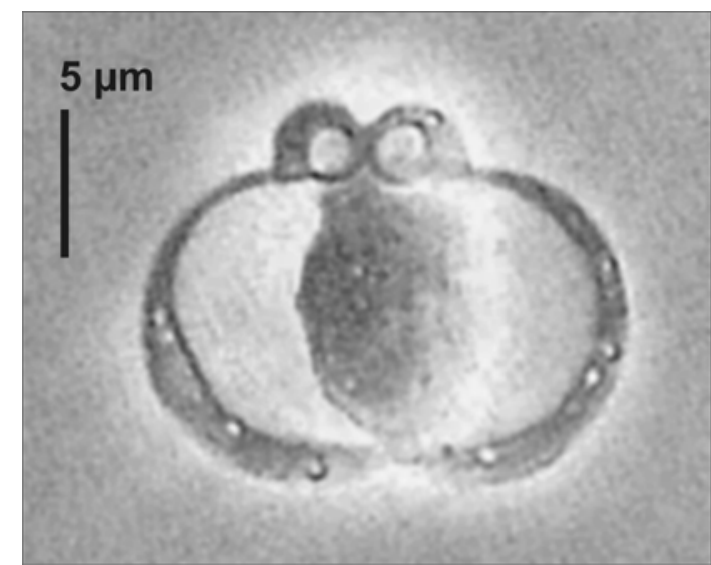

Fig. 2. Photograph of a fishmalacospore of Tetracapsuloides bryosalmonae (Courtesy of Dr. R.P. Hedrick and Parasitol. Res.).

to have spherical, two-valved spore with a single polar capsule, and has trophozoites not corresponding to myxosporean developmental stages (Sundara Rajulu et Radha 1966). Myxobolus labracis Abdel-Aal, Badawy et Gattas, 2001 was reported from a cerambycid beetle Moron labrosus in Egypt (Abdel-Aal et al. 2001).

The invertebrates known thus far as definitive hosts for actinospores are oligochaetes (mostly tubificids) from freshwater, and some from the marine environment. In marine polychaetes, actinospores of the tetractinomyxon type have been reported (Køie 2005a). A few actinospores have been found in marine sipunculids. The actinospore phases of only 32 myxosporean species from freshwater environment have been known, while only one was found in the genuinely marine environment (Ellipsomyxa gobii with stages in Nereis spp. Køie et al. 2004).

\section{Classification}

The taxonomy which persists until now follows largely Lom and Noble (1984). The drawback is that the main criterion of classification is the spore morphology, namely the number and configuration of shell valves and polar capsules. This spore-based taxonomy is generally artificial, clearly at the family level and with quite vague boundaries between many genera such as Leptotheca and Ceratomyxa, Myxidium and Zschokkella, or between some species of Myxobolus and Thelohanellus. It also does not reflect the life cycle with alternation of hosts, morphology of actinospores within the definitive invertebrate hosts, host and tissue preferences and first of all, phylogenetic relationships as revealed by SSU rDNA analyses. All morphological features important in describing species in the myxospore and actinospore stage are listed in Lom and Arthur (1989) and Lom et al. (1997a).

Designation of a separate class, the Malacosporea, is in agreement with their forming a separate clade in a root-like position from which myxosporean clades diverge. However, in other respects the molecular ap- proach does not in the least support the existing myxosporean taxonomy (Kent et al. 2001; I. Fiala, Inst. Parasitol. AS CR, České Budějovice, pers. comm. - see References). The two main myxosporean clades are not based on similarities of spore morphology of the taxa included but, surprisingly, according to freshwater or marine habitat of their hosts. Thus representatives of several genera (Myxidium, Sphaerospora, Zschokkella) are found within both major clades. These clades are subdivided into subclades, where the grouping of genera and species does not always correspond to spore structure. Several species having similar spores, i.e., belonging to the same genus, are distributed separately in phylogenetic trees, while species from morphologically different genera cluster together. The subclades follow to a great extent the coelozoic vs. histozoic way of life.

It would be beyond the scope of this introduction to deal in detail with all the subclades assigned to the two major clades in the above mentioned papers. We can just briefly mention that within the marine clade, according to Fiala (pers. comm.), Ceratomyxa species group together with Palliatus indecorus. Myxidium species, Auerbachia pulchra and Ellipsomyxa gobii cluster with Zschokkella mugilis. Most (not all) of the Kudoa species analysed form what seems a monophyletic clade.

A rather basal phylogenetic position of coelozoic "marine" myxosporeans (e.g., species of the genera $A u$ erbachia, Ceratomyxa, Enteromyxum or Palliatus Fiala, pers. comm.) reminds of Shulman's (1966) suggestion that myxosporeans were originally coelozoic in marine teleosts, from which they evolved to parasitize freshwater hosts.

In the large freshwater clade there are also groupings of genera and species opposing their morphology-based relationship. Thus freshwater coelozoic species of the genera Chloromyxum, Zschokkella and Myxidium cluster together with purely marine species of the genus Sphaeromyxa (Fiala, pers. comm.). In the group of Sphaerospora oncorhynchi, Myxidium lieberkuehni and Chloromyxum legeri (Kent et al. 2001; Fiala, pers. comm.) the coelozoic way of life is the unifying element, while spore morphology is different. Interestingly, histozoic species of Myxobolus and Henneguya form branches that are often close to each other (Cone and Easy 2005; Fiala, pers. comm.).

However preliminary the categories indicated in the clades may be, they might suggest the future outlines of the classification. It would be desirable to find some other features, in addition to molecular analysis, to support them. Histozoic parasitism must have evolved several times both in marine and freshwater fishes and it is only to some extent indicative of evolution of pertinent taxa.

The reliability of the cladograms of course depends on correct identification of the species sequenced, which may not be always safe (e.g., sequences of the "marine" species Myxobolus muelleri or M. exiguus in GenBank). 
The molecular data, being still very incomplete and based on a single gene, are far from being sufficient to launch a well substantiated new classification - a situation similar to that in microsporidia (Vossbrinck and Debrunner-Vossbrinck 2005, Larsson 2005). Future classification of Myxosporea should represent a synthesis of molecular phylogeny and the combined evidence of both life-cycle stages, if known (Xiao and Desser 2000). Taxonomic relationship of a myxosporean should also take into account tissue tropism (Molnár 2002), which may reflect rRNA grouping of the species in question (Andree et al. 1999). Also geographic origin may be decisive, as Hervio et al. (1997) have shown in Kudoa species, which cluster according to such origin rather than by spore morphology. The matter is not yet settled; more recently, Yokoyama and Itoh (2005) have shown that the degree of sequence similarity does not comply with geographic distribution. Andree et al. (1999), working with species of the genus Myxobolus, found that morphological features are not necessarily good indicators of true genetic relationship at the species level, which also applies to species of other genera. Host specificity should also be considered; it may be strict in some species but rather wide in others (Nielsen et al. 2002).

References: Andree et al. (1999), Salim and Desser (2000), Kent et al. (2001), Dyková et al. (2002), Eszterbauer and Székely (2004), Holzer et al. (2004), Cone and Easy (2005).

Considering this very complicated situation, we retain for the time being the existing classification, preferring it to a merely alphabetical listing of genera compiled under a similarly confusing situation in microsporidians (e.g., Canning and Vávra 2000, Lom 2002). We list in the following text updated definitions of all myxosporean genera with remarks, which might be relevant for better understanding the organisms, and add some references, which can serve as sources of further information. In most genera, in addition to the type species, we list pathogenic species important in contemporary pisciculture and for sport fisheries in freshwater or sea. Names of the fish hosts follow Froese and Pauly (2005).

Important publications on taxonomy and morphology of Myxosporea as a group include Davis (1917), Kudo (1919), Ward (1919), Fujita (1923), Pinto (1928), Poisson (1953), Tripathi (1953), Shulman (1962, 1966, 1984), Chen (1973), Mitchell (1979), Uspenskaya (1984), Marques (1986-1987), Lom and Dyková (1992, 1997), Moser and Kent (1994), Goia and Cordeiro (1996), Fomena and Bouix (1997), Lom et al. (1997b), Shulman et al. (1997), Chen and Ma (1998), and Hoffman (1999).

Selected publications on myxosporean pathogenicity include Hofer (1904), Plehn (1924), Sindermann (1970), Lom (1985), Dyková and Lom (1988), Schäperclaus (1992), Alvarez-Pellitero and Sitjà-Bobadilla (1993), Kent et al. (1994b, 2001), Lom and Dyková (1995a), Noga (1995), and Longshaw et al. (2005).

\section{Myxosporean genera}

According to Shulman (1966), there were 731 species of myxosporeans; as of October 2005, 60 genera with 2,180 species have been recorded, many of them regrettably established without complete morphological or molecular data. In this current classification only named species are considered. Most of these species can not be properly revised until there is sufficient resolution provided both by detailed morphological study and molecular analysis, so that numbers given for each genus may eventually be lower or perhaps even higher. Certainly, a large number of species still remain to be discovered.

\section{ORder Bivalvulida Shulman, 1959}

Spore shell is composed of two valves meeting in one circumsporal line of dehiscence or suture. Spore contains two, sometimes four or rarely one polar capsule, and one, rarely two sporoplasms.

\section{SUbORDER SPHAEROMYXINA Lom et Noble, 1984}

Polar filament is short, and at variance with all other Myxosporea, not tube-like but flat, being very broad at the base and gradually tapering to the end. In the polar capsule it is folded several times instead of being spirally wound. Plasmodia are coelozoic in the gall bladder of marine fishes. The separateness of this suborder has thus far not been confirmed by SSU rDNA analysis.

\section{S p h a e r o m y x i d a e Lom et Noble, 1984}

Spore elongated, sometimes slightly curved; the two polar capsules lie in its opposite, tapering and truncate ends. Spores open at the level of the suture line, bisecting the spore and connecting its both ends. Shell valves smooth or ridged. One, binucleate sporoplasm. Plasmodia large (sometimes several $\mathrm{mm}$ in size), form disporic pansporoblasts and float free in the gall bladder. Pathogenicity has not been proved.

Sphaeromyxa Thélohan, 1892

Fig. 3

With characters of the family. Number of species: 39 .

References: fine structure - Lom (1969), list of species Lom (2004).

Type species Sphaeromyxa balbianii Thélohan, 1892 (Fig. 3 ); originally recorded hosts (without specification of the type host) are Gaidropsarus vulgaris (syn. Motella tricirrata and M. maculata), Cepola macrophthalma (syn. C. rubescens); later found also in other host species in the Mediterranean Sea and in the Atlantic Ocean off European coasts.

\section{SUBORDER VARIISPORINA Lom et Noble, 1984}

Polar capsules - one or two, sometimes four- are in various positions in the spore. When they are located at one pole of the spore they do not lie solely in the sutural plane or they may lie in a plane perpendicular to it. Mostly coelozoic, most of the genera live in marine fishes.

\section{Myx id i id a e Thélohan, 1892}

Spores mostly elongated, spindle-shaped, sigmoid or crescent-shaped, some are almost semicircular in valvular view. Generally two polar capsules in opposite ends discharge terminally or more or less laterally. The longitudinal sutural line is straight, curved or sigmoid. As a rule coelozoic, rarely histozoic parasites in marine and freshwater fishes. 
Myxidium Bütschli, 1882

Synonym: Cystodiscus Lutz, 1889

Spores are generally fusiform, straight or slightly crescent or even sigmoid, with more or less pointed ends. Shell valves smooth or with ridges, sutural line bisects the spore. Two polar capsules, mostly pyriform, lie one at each end of the spore. Capsular foramina are situated in the sutural plane, at or near the end of the spore and open as a rule in opposite directions. The binucleate sporoplasm lies between the capsules. The species are typically coelozoic (rarely histozoic), forming small or large trophozoites, mono-, di- or polysporic, the latter with pansporoblast formation. The heterogeneity of the genus is illustrated by representation in different phylogenetic clades and by development into actinospores of different collective groups. A total of 205 species infect marine and freshwater fishes with 8 species in amphibians and 4 in reptiles.

In only one species has the complete developmental cycle been experimentally revealed: in Myxidium giardi the actinospore stage is aurantiactinomyxon (Benajiba and Marques 1993). Molecular analysis identified a raabeia type with $M$. truttae (Holzer et al. 2004).

References: species reported from eels in Hine (1980); list of species in Jayasri and Hoffman (1982); fine structure in Benajiba et al. (1993) and Canning et al. (1999a).

Type species Myxidium lieberkuehni Bütschli, 1882 (Fig. 4); type host Esox lucius, site of infection is the urinary tract; in the whole Holarctic region with prevalence often up to $100 \%$ (Lom et al. 1989).

Pathogenic species: Myxidium truttae Léger, 1931 causes serious infections of bile ducts and liver of salmonids in Eurasia (McGeorge et al. 1996a, b).

Enteromyxum Palenzuela, Redondo et Alvarez-Pellitero, 2002

Fig. 5

Spores slightly crescent-shaped; very large and elongated polar capsules taper to their distal side and open at the ends of the spore. They discharge in opposite directions relative to the longitudinal plane, bisecting the spore in top or bottom view. The rather inconspicuous suture line is nearly transversal. One, binucleate sporoplasm. Spores develop in disporic pseudoplasmodia. Histozoic parasites in epithelia of digestive tract (including sometimes the gall bladder) of marine fishes causing acute enteritis, cachexia and death in susceptible fish. Number of species: 3 .

Type species Enteromyxum scophthalmi Palenzuela, Redondo et Alvarez-Pellitero, 2002 (Fig. 5) causes enteritis and death of turbots Psetta maxima (syn. Scophthalmus maximus) cultured in Spain. Experimental direct transmission was successful (Redondo et al. 2004).

Pathogenic species: Enteromyxum fugu (Tun, Yokoyama, Ogawa et Wakayabashi, 2002) Yanagida, Nomura, Kimura, Fukuda, Yokoyama et Ogawa, 2004 (syn. Myxidium fugu) and Enteromyxum sp. described by the later authors are agents of emaciation disease in maricultures of Takifugu rubripes in Japan. They can also be transmitted directly from fish to fish in sea cages (Yasuda et al. 2002). E. leei (Diamant, Lom et Dyková, 1994) Palenzuela, Redondo et Alvarez-Pellitero, 2002 (syn. Myxidium leei), a pathogen in the intestine of Sparus aurata and many other sparid fishes (Padros et al. 2001), has according to Diamant (1997) a unique, direct transmission from fish to fish, in which, however, not spores but proliferative stages releasing infective cells may be instrumental (Branson et al. 1991). $\begin{array}{lr}\text { Zschokkella Auerbach, } 1910 & \text { Fig. } 6 \\ \text { Synonym: Parazschokkella Kalavati et Narasimhamurti, } 1987\end{array}$

Spores ellipsoidal in sutural view and slightly bent or semicircular in valvular view, with rounded or bluntly pointed ends. Shell valves smooth or with ridges. The suture is straight, curved or sinuous. Polar capsules almost spherical, open slightly subterminally and both to one side; the sporoplasm is binucleate. Trophozoites disporic to polysporic, the latter with pansporoblast formation. The genus with species represented in different phylogenetic clades is heterogenous in forming different actinospore stages. In the future it may be split in several genera. Morphological distinction between the genera Myxidium and Zschokkella is sometimes extremely difficult; e.g., some important diagnostic features of Myxidium triangulum Shulman, 1962 or M. monstruosum Shulman, 1962 assign it to Zschokkella, while e.g., Zschokkella costata Kashkowsky, 1965 has features of Myxidium. Molecular analysis does not help too much thus far - some species of both genera cluster together, some are wide apart (Fiala, pers. comm.). The total of 68 species (mostly coelozoic, exceptionally histozoic) in marine and freshwater fishes, 2 additional species in amphibians and 2 in reptiles.

In two species only the complete developmental cycle was revealed: in Zschokkella nova the actinospore stage is a siedleckiella (Uspenskaya 1995) and in Zschokkella sp. an echinactinomyxon (Yokoyama et al. 1991).

Reference: Sitjà-Bobadilla and Alvarez-Pellitero (1993b).

Type species Zschokkella hildae Auerbach, 1910 (Fig. 6) described originally from the urinary bladder of Phycis blennoides, Gadus morhua (syn. G. callarias) and Pollachius virens (syn. Gadus virens) without specification of the type host was also found in some other gadid fishes in North European seas and the Atlantic.

Pathogenic species: Zschokkella icterica Diamant et Paperna, 1992 causes cholestasis and bile duct breakdown in Siganus luridus from the Red Sea. It may also invade liver parenchyma (Diamant and Paperna 1992).

Coccomyxa Léger et Hesse, 1907

Fig. 7

Spores ellipsoidal rounded in transverse section, with a single elongated polar capsule (the second presumably lost), which opens in the sutural plane. Sutural line sigmoid, sporoplasm binucleate. Trophozoites are mono- or polysporic. Based on SSU rDNA sequences, species of this genus are phylogenetically closely related to Zschokkella and Enteromyxum (Diamant and Palenzuela 2005). Coelozoic in marine fishes, one species histozoic (C. hoffmani Cheung et Nigrelli, 1990 in gill cartilage of Plotosus anguillaris). Number of species: 13 .

Type species Coccomyxa morovi Léger et Hesse, 1907 (Fig. 7) from the gall bladder of Sardina pilchardus from the Mediterranean and Celtic Seas and the English Channel.

\section{O r t h o 1 in e i d a e Lom et Noble, 1984}

Spores spherical to irregularly ellipsoidal and bilaterally symmetrical along the straight sutural line. Two anteriorly located polar capsules shifted widely sidewise in the sutural plane. Capsular foramina are directed away from each other at a certain angle. Binucleate sporoplasm in the posterior part of the spore. Coelozoic, mono- to polysporic plasmodia, in marine and freshwater fishes. The assignment of the genera $\mathrm{NeO}$ myxobolus and Triangula to the family is rather tentative. 
Ortholinea Shulman, 1962

Fig. 8

Spores spherical to subspherical, may be slightly flattened parallel to the sutural plane or may be pointed posteriorly. Polar capsules are subspherical to pyriform. Coelozoic, in the urinary system of marine fishes. Number of species: 12 .

Type species Ortholinea divergens (Thélohan, 1895) Shulman, 1962 (Fig. 8) in the urinary system of Lipophrys pholis (syn. Blennius pholis) and Symphodus melops (syn. Crenilabrus melops) from the northern coast of France, also infects other marine fishes.

Neomyxobolus Chen et Hsieh, 1960

Fig. 9

Spores ovoid, in valvular view wider than long. Anterior end flattened, posterior semicircular, flattened parallel to the sutural plane. Binucleate sporoplasm may contain an iodinophilous vacuole. In the urinary tract of freshwater fishes. Number of species: 3 .

Type species Neomyxobolus ophiocephalus Chen et Hsieh, 1960 (Fig. 9) in renal tubules of the freshwater fish Channa argus (syn. Ophiocephalus argus) and C. maculata (syn. $O$. maculatus) in China.

Cardimyxobolus Ma, Dong et Wang, 1982

Fig. 10

Spores in frontal view oval, with one side very vaulted and with sutural markings along the posterior border; spindleshaped in sutural view. Subspherical polar capsules. Shell valves are smooth, in the sporoplasm is an iodinophilous vacuole. Polysporic plasmodium is histozoic. Number of species: 2. A thorough differentiation from Neomyxobolus is still needed.

Type species Cardimyxobolus leshanensis Ma, Dong et Wang, 1982 (Fig. 10) in the gills of Garra imberba (syn. G. pingi) in China.

\section{Triangula Chen et Hsieh, 1984}

Fig. 11

Spores triangular but very rounded, anterior end wider; they are flattened parallel to the sutural plane. Their surface is smooth, polar capsules subspherical, binucleate sporoplasm contains an iodinophilous vacuole. Histozoic, polysporic plasmodia in freshwater fishes. Number of species: 3 .

Type species Triangula yangkiangensis Chen et Hsieh, 1984 (Fig. 11) in the skin and gills of Rhinogobius giurinus and Rhodeus lighti (syn. Pseudosperilampus lighti) in China (Chen and Hsieh 1984a).

Azevedo et al. (2005) proposed a new genus Triangulamyxa with a single species $T$. amazonica Azevedo, Corral et Matos, 2005 (Fig. 12) forming coelozoic plasmodia attached to the surface of the intestine of Amazonian freshwater fish Sphaeroides testudineus. The differences from Triangula are, however, not very pronounced (histozoic vs. coelozoic plasmodia, smooth vs. wrinkled spore surface so that the independence of Triangulamyxa warrants confirmation.

Kentmoseria Lom et Dyková, 1995

Fig. 13 Synonym: Paraortholinea Kovaleva in Shulman et al. 1997

Elongated spores, wider anteriorly than posteriorly, slightly flattened parallel to the straight suture. Pointed projections extend backwards from the posterior half of the smooth shell valves. Pyriform polar capsules open laterally. Plasmodia mono- to disporic, coelozoic in the urinary tract of marine fishes.

Type and only species Kentmoseria alata (Kent et Moser, 1990) Lom et Dyková, 1995b (syn. Paraortholinea alata Kovaleva, 1997) (Fig. 13) described from lumina of renal tubules and collecting ducts of the marine fish Chaetodon rainfordi from the Great Barrier Reef off Australia.

\section{S i n u o lin e i d a e Shulman, 1959}

Spores spherical or inversely pyramidal, may have caudal or lateral projections. Two spherical or subspherical polar capsules are anteriorly located and set apart, sometimes even at opposing sides of the spore; the plane connecting them is perpendicular to the mostly sinuous or meandering sutural line which often appears as a figure " 8 ". Plasmodia mono- to polysporic, located in the urinary system of marine fishes.

Sinuolinea Davis, 1917

Fig. 14

Spores spherical or subspherical, sutural line sinuous or extremely meandering so that its orientation to the two polar capsules, which are set widely apart, is sometimes difficult to assess. Sporoplasm binucleate, plasmodia mono- to polysporic. Number of species: 21.

Type species Sinuolinea dimorpha (Davis, 1916) Davis, 1917 (Fig. 14) described from the urinary system of the marine fish Cynoscion regalis along the U.S. Atlantic coast.

Davisia Laird, 1953

Fig. 15

Spores spherical or subspherical, sutural line straight or sinuous. Shell valves extend into long hollow lateral appendages, the cavity of which is discontinuous with the spore cavity. Polar capsules lie anteriorly at a certain distance from each other. Trophozoites mono-, di- and polysporic. Number of species: 19.

Reference: list of species - Aseeva (2002).

Type species Davisia diplocrepis Laird, 1953 (Fig. 15) common in the urinary bladder of the marine fish Diplocrepis puniceus in New Zealand waters.

Myxoproteus Doflein, 1898

Fig. 16

Synonym: Conispora Sankurathri, 1977

Spores inversely pyramidal or triangular in sutural view, with rounded outlines. Anterior end broad and more or less flattened. Thick spore valves may have various projections. Sutural line straight or sinuous. Polar capsules lie well apart, sporoplasm binucleate. Trophozoites mono- to polysporic. Number of species: 7.

Type species Myxoproteus ambiguus (Thélohan, 1895) Doflein, 1898 in the urinary bladder of the marine fish Lophius piscatorius. (In the absence of a reliable picture of the type species, Fig. 16 shows M. abyssus Yoshino et Moser, 1974 adapted from their original paper).

Bipteria Kovaleva, Zubchenko et Krasin, 1983

Fig. 17

Spores inversely pyramidal in sutural view with pointed end extending backwards. In transverse section, the spore is ellipsoid. Suture sinuous. Anterior end of each shell valve extends into a wing-like projection containing parts of valvogenic nucleus. Polar capsules spherical, a single sporoplasm. Plasmodia di- and polysporic. Number of species: 8.

Type species Bipteria admiranda Kovaleva, Zubchenko et Krasin, 1983 (Fig. 17) described from the urinary bladder of the marine fish Pagellus acarne from the East-Central Atlantic.

\section{Paramyxoproteus Wierzbicka, 1986}

Fig. 18

Like Bipteria, but valvular projections are shaped like stiff, keel-like, meridionally running membranes. The suture line runs obliquely to the plane of the two polar capsules; in the original description, its course cannot be unambiguously discerned, so that the status of the genus warrants further study. Kovaleva (1989) takes it for a junior synonym of Myxoproteus. Number of species: 2 . 
Type species Paramyxoproteus reinhardti Wierzbicka, 1986 (Fig. 18) described from the urinary bladder of Reinhardtius hippoglossoides in the Atlantic off Labrador and in the Barents Sea.

Neobipteria Kovaleva, Gaevskaya et Krasin, 1986 Fig. 19

Like Bipteria, but with keel-like extensions running meridionally along the sutural line. Type and only species Neobipteria macrouri Kovaleva, Gaevskaya et Krasin, 1986 (Fig. 19) in the urinary bladder of Coryphaenoides acrolepis in the Bering Sea and in the Pacific off Kuril Islands.

Schulmania Kovaleva, Zubchenko et Krasin, 1983 Fig. 20

Differs from Bipteria in having sometimes straight sutural line, mono- or disporic trophozoites and mainly four longitudinal, keel-like, stiff membranes. Two of them run along the sutural line, two others extend along the middle line of each shell valve. Number of species: 10 .

Type species Schulmania ovale Kovaleva, Zubchenko et Krasin, 1983 (Fig. 20) described from the urinary bladder of marine fish Lycodes esmarkii in the Atlantic Ocean off the Newfoundland and Labrador coasts.

\section{Noblea Kovaleva, 1989}

Fig. 21

Spores inversely pyramidal and rounded. Two keel-like membranes extend along the slightly wavy sutural line; two thickenings adhere to but are slightly raised off the apex of the spore. Wide ends of the thickenings cover the polar capsules and the tapering ends extend backwards along the spore surface. Plasmodia mono- or disporic.

Type and only species Noblea admiranda Kovaleva, 1989 (Fig. 21) described from the urinary bladder of Urophycis chuss off the Canadian Atlantic coast at Sable Island.

\section{F a b e s p o r i d a e Naidenova et Zaika, 1969}

Spores have valves elongated in the direction perpendicular to the plane of the central transverse sutural line. Two polar capsules in the opposite spore ends discharge terminally or laterally. Coelozoic in marine fishes and in the parenchyma of a platyhelminth.

\section{Fabespora Naidenova et Zaika, 1969}

Figs. 22, 23

With characters of the family; disporous trophozoites. In capsulogenesis the external tube is missing. Sporoplasm binucleate. Number of species: 2 .

Type species Fabespora nana Naidenova et Zaika, 1969 (Fig. 22) originally described from the gall bladder of three marine fishes Mesogobius batrachocephalus, Scorpaena porcus and Proterorhinus marmoratus in the Black Sea.

Fabespora vermicola Overstreet, 1976 (Fig. 23) was described from the digenean parasite Crassicutis archosargi of the estuarine sparid fish Archosargus probatocephalus from Mississippi state, USA. The assignment to the genus may rise doubts. Spores can exhibit a weak movement due to contractile fibres fastened up to the shell valves. This is the only case of spore movement among Myxosporea (Weidner and Overstreet 1979)

\section{Ce r a t o m y x i d a e Doflein, 1899}

The two valves of the spores are elongated or drawn out to an enormous length in the direction perpendicular to the straight central transverse suture. Sometimes the two valves are asymmetrical. Polar capsules close to the suture line, in a plane perpendicular to it, are spherical or subspherical and have foramina near the sutural line at the anterior pole of the spore. Plasmodia mostly disporic, sometimes mono- to polysporic. Coelozoic in marine fishes, rarely histozoic in freshwater fishes.

Reference: Meglitsch (1960).

Ceratomyxa Thélohan, 1892

Figs. 24, 25

Spores elongated, as a rule crescent-shaped or arcuate, thin shell valve exceeds in length the axial diameter of the spore. Shell valves often pliable rather than being rigid as in other genera. Subspherical polar capsules are located and open as is typical of the family, exceptionally they open laterally from the central suture line. Binucleate sporoplasm does not fill the spore cavity completely; in some species, two uninucleate sporoplasms were reported. Trophozoites usually disporic, sometimes mono- to polysporic. Coelozoic parasites of marine fishes. There are at least five species from freshwater hosts, obviously derived from marine ancestors: Ceratomyxa anguillae Tuzet et Ormières, 1957 from the gall bladder of Anguilla anguilla from Mediterranean brackish waters, $C$. hilsae Chakravarty, 1943 from the gall bladder of the anadromous Indian fish Tenualosa ilisha (syn. Hilsa ilisha), C. hongzhensis Hsieh et Chen, 1984 from the gall bladder of Pelteobagrus eupogon (syn. Pseudobagrus eupogon) from China, C. hungarica Molnár, 1992 from Bowman's capsules and renal tubules of freshwater goby Proterorhinus marmoratus from the Danube river basin, and C. shasta Noble, 1950. The latter is a dangerous pathogen of North American salmonids, histozoic in the digestive tract (Margolis and Evelyn 1975, Bartholomew 1998). Although it adapted to a freshwater fish, phylogenetic analysis based on the SSU rDNA places it in the clade of marine myxosporeans (Kent et al. 2001). Its actinospore stage, a tetractinomyxon, lives in a benthic freshwater polychaete, Manyunkia speciosa (Bartholomew et al. 1997). Number of species: 172.

References: Bartholomew et al. (1989); partial list of species - Aseeva (2003), ultrastructure and development of the piscine phase - Cho et al. (2004).

Type species Ceratomyxa arcuata Thélohan, 1892 (Fig. 24) originally described from the gall bladder of Gaidropsarus vulgaris (syn. Motella tricirrata), Symphodus melops (syn. Crenilabrus melops), Pagellus bogaraveo (syn. P. centrodontus), Scorpaena porcus and S. scrofa in the Mediterranean.

Other pathogenic species: Ceratomyxa sparusaurati SitjàBobadilla, Palenzuela et Alvarez-Pellitero, 1995 (Fig. 25) inflicts damage in the gall bladder of cultured Sparus aurata (Palenzuela et al. 1997).

Leptotheca Thélohan, 1895

Fig. 26

Spores oval, ellipsoidal, sometimes arcuate. The length of the individual laterally prolonged shell valve —as measured from the midpoint of the suture to the most distant point of the valve - does not exceed the axial diameter of the spore (i.e., difference from Ceratomyxa) but significantly exceeds one half of this diameter. In some cases, the distinction between Ceratomyxa and Leptotheca is quite problematic. Sporoplasm often fills the spore cavity completely; usually one binucleate but sometimes two uninucleate sporoplasms. Trophozoites generally disporic. Species coelozoic in the gall bladder or urinary system in marine fishes, rarely histozoic. Number of species: 56 , one of which in the urinary system of amphibians and one in reptiles.

Type species Leptotheca agilis (Thélohan, 1892) Thélohan, 1895 (Fig. 26) originally described from the gall bladder of marine fish Dasyatis pastinaca (syn. Trygon pastinaca) and of a species of the genus Scorpaena along the French coast. 


\section{Meglitschia Kovaleva, 1988}

Fig. 27

Differs from Ceratomyxa by an almost V-shaped spore; elongate polar capsules lie almost axially in each valve. Coelozoic, polysporic trophozoites.

Type and only species Meglitschia insolita (Meglitsch, 1960) Kovaleva, 1988 (Fig. 27) in the gall bladder of the marine fish Dactylopagrus macropterus from off New Zealand.

\section{Ellipsomyxa Køie, 2003}

Fig. 28

Spores elongated in direction perpendicular to the straight central transverse suture. Thin-walled valves hemispherical to elongate. Two equal spherical polar capsules at some distance from sutural plane on opposite sides of the spore close to the surface, discharging in opposite directions. Disporic plasmodia coelozoic in the gall bladder of marine fish.

Type and only species Ellipsomyxa gobii Køie, 2003 (Fig. 28 ) in the marine fish Pomatoschistus microps in the sea near Helsingør, Denmark. Forms tetractinomyxon actinospore stages in definitive hosts, polychaetes of the genus Nereis (Køie 2003a, Køie et al. 2004).

\section{S phaeros porid a e Davis, 1917}

Spores generally spherical or subspherical, sometimes rounded pyramidal with tapering anterior end or slightly elongated, often with appendages. Two polar capsules open at the anterior tip and are situated in a plane perpendicular to the straight sutural line. Trophozoites mono- or disporic, less often polysporic. Mostly coelozoic in marine and freshwater fishes, sometimes histozoic.

Reference: Meglitsch (1970).

Sphaerospora Thélohan, 1892

Synonym: Podospora Chen et Hsieh, 1984

Figs. 29, 30

Spherical or subspherical spores, valvular diameter equals and only in a few species significantly exceeds the sutural diameter. Valves smooth or ridged, often with posterior or lateral protuberances or bumps, like in S. plagiognathopsis (Chen et Hsieh, 1984). The sutural ridge often prominent, polar capsules subspherical or pyriform. Two uninucleate sporoplasms. Mono- or disporic trophozoites are coelozoic, mainly in the urinary system of freshwater and marine fishes, some are histozoic. In its present conception, the genus is polyphyletic, with species distributed in different freshwater and marine clades. Coelozoic species from the urinary system usually seem to be host specific and have easy to find pre- and extrasporogonic stages in blood and various other tissues. Many species are pathogenic. Number of species: 78, one of which in anuran amphibians.

Complete life cycle has been revealed in two species: Sphaerospora renicola (see below); in S. truttae occurs the echinactinomyxon stage (Özer and Wootten 2000).

References: key to species - Sitjà-Bobadilla and AlvarezPellitero (1994); fine structure - Sitjà-Bobadilla and AlvarezPellitero (1992), McGeorge et al. (1994), Dyková and Lom (1997).

Type species Sphaerospora elegans Thélohan, 1892 (Fig. 29) occurs in renal tubules and connective tissue of the ovarium of Gasterosteus aculeatus and Pungitius pungitius in France and UK (Feist et al. 1991).

Pathogenic species: Sphaerospora ictaluri Hedrick, McDowell et Groff, 1990 commonly infects renal tubules of farmed alevins of Ictalurus punctatus in California. Its developmental stages are the possible cause of the "hamburger disease" of this host (Hedrick et al. 1990). S. molnari Lom, Dyková, Pavlásková et Grupcheva, 1983, a histozoic species largely distributed in the gills of common carp, Cyprinus car- pio, in Europe (Molnár 1979a, Lom et al. 1983b, Svobodová and Groch 1986). S. renicola Dyková et Lom, 1982 (Fig. 30) is a widely distributed and serious pathogen in renal tubules of cultured common carp, Cyprinus carpio, throughout Eurasia, Israel and Australia. The definitive host is the oligochaete Branchiura sowerbyi, in which neoactinomyxum stage develops (Grossheider and Körting 1993, Molnár et al. 1999b). Odening et al. (1989) claimed a direct transmission by means of spores or infected kidney tissue. This finding warrants reexamination. Curiously, this species and $S$. molnari are sister species (Eszterbauer and Székely 2004). S. testicularis SitjàBobadilla et Alvarez-Pellitero, 1990 in seminiferous tubules in the testes of cultured Dicentrarchus labrax in the Mediterranean (Sitjà-Bobadilla and Alvarez-Pellitero 1993a). S. tincae Plehn, 1925 in pronephros of Tinca tinca in Europe (Hermanns and Körting 1985). S. truttae Fischer-Scherl, ElMatbouli et Hoffmann, 1986 in the renal tubules of Salmo trutta in Europe (McGeorge et al. 1996a, Holzer et al. 2003).

References: Sphaerospora renicola, blood phase - Lom et al. (1983a), Grupcheva et al. (1985); swimbladder phase Csaba et al. (1984), Körting et al. (1984), Molnár and KovacsGayer (1986b), Odening et al. (1988), Dyková et al. (1990).

Polysporoplasma Sitjà-Bobadilla et Alvarez-Pellitero, 1995

Fig. 31

Differs from Sphaerospora in having many uninucleate sporoplasms; 4 to 12 are observed in one plane of section. Disporous pseudoplasmodia in urinary tract and kidney tissue. Number of species: 2.

Type species Polysporoplasma sparis Sitjà-Bobadilla et Alvarez-Pellitero, 1995 (Fig. 31), a serious pathogen in glomeruli, tubuli or connective tissue of trunk kidney of Sparus aurata in fish farms at the Atlantic and Mediterranean coasts of Spain (Palenzuela et al. 1999).

Hoferellus Berg, 1898

Fig. 32 Synonyms: Hoferia Doflein, 1898; Mitraspora Fujita, 1912

Spores in valvular view pointed, mitre-like or completely rounded, with many stiff filaments at the posterior end. Polar capsules pyriform, sporoplasm binucleate, trophozoites polysporic, without pansporoblast formation. Complete life cycle revealed in two species. Coelozoic in the urinary system of freshwater fishes, some with conspicuous intracellular development. Number of species: 25, one of which is pathogenic in frogs (Mutschmann 2004).

The taxonomy of Hoferellus, as based on Kudo (1919), is a puzzle: how could have Berg (1898) in a short note in Buenos Aires established a genus without marking out as a type species, the only species, of the genus known at that time (1919) ? To avoid further confusion, let us consider the genus as proposed by Kudo (1919) for the time being a nomen conservandum.

References: discussion on taxonomy - Lom (1986); fine structure - Lom et al. (1986).

Type species Hoferellus cyprini (Doflein, 1898) Mercier, 1908 (Fig. 32) is a common pathogen in the urinary system of common carp, Cyprinus carpio in Eurasia. Actinospore phase represented by aurantiactinomyxon stage (Grossheider and Körting 1992).

Hoferellus carassii Akhmerov, 1960 in the kidney of Carassius auratus auratus in Eurasia and North America. In Asia and USA it is the agent of goldfish kidney enlargement disease, known as "kidney bloater" (Ahmed 1974, Molnár et al. 1989, Trouillier et al. 1996). Actinospore phase found to be an aurantiactinomyxon (according to El-Matbouli et al. 1992a) or neoactinomyxum stage (Yokoyama et al. 1993); this indicates the uncertain identification of this species. 
Wardia Kudo, 1919

Fig. 33

Spores oval in valvular view but resemble a double isosceles triangle with two convex sides in sutural view and flattened perpendicularly to the sutural plane. Fine ridges on the surface of the valves run into fringe-like processes at the posterior end. Large polar capsules in the central part of the spore open at the anterior tip of the spore. Large, histozoic polysporic plasmodia appear like cysts. The status of the genus has to be re-examined to exclude identity with Sphaerospora. Number of species: 3 in freshwater fishes.

Type species Wardia ovinocua Kudo, 1919 (Fig. 33) described from oocytes and connective tissue in ovaries of $\mathrm{Le}$ pomis humilis in Illinois, USA.

Palliatus Shulman, Kovaleva et Dubina, 1979

Fig. 35

Spores subspherical, with anteriorly prominent sutural ridge and enveloped in a membranaceous veil, which in immature spores is twisted in two cords around the spore. Polar capsules pyriform, sporoplasm binucleate. Coelozoic trophozoites in the gall bladder of marine fishes produce 1 to 6 disporic pansporoblasts. Contrary to morphology of spores, phylogenetic analysis showed the genus as closely related to Ceratomyxa (Fiala, pers. comm.). Number of species: 6 .

Type species Palliatus mirabilis Shulman, Kovaleva et Dubina, 1979 (Fig. 35) in the gall bladder of the marine fish Xenodermichthys copei (syn. X. socialis) off Guinea-Bissau.

\section{Myxobilatus Davis, 1944}

Fig. 34

Elongated spores are anteriorly pointed. Shell valves often with fine ridges extend posteriorly into two caudal appendages. Polar capsules pyriform in the level perpendicular to the sutural plane, binucleate sporoplasm may contain an iodinophilous vacuole. Coelozoic trophozoites, small or large, disporic or polysporic with pansporoblast formation, occur all the length through the urinary system. They are rarely histozoic. Number of species: 33 in freshwater and marine fishes.

References: discussion on taxonomy - Lom (1986); fine structure - Booker and Current (1981).

Type species Myxobilatus gasterostei (Parisi, 1912) Davis, 1944 (Fig. 34) described from renal tubules of the freshwater and estuarine fish Gasterosteus aculeatus in Eurasia.

\section{C h 1 o r o m y x i d a e Thélohan, 1892}

Spores spherical, subspherical or slightly elongated are bisected by a straight meridional suture. They may bear fine caudal appendages. Four polar capsules are located at the spore apex: either one pair in the level of the sutural line and the second pair perpendicularly to the suture, or both pairs diagonally beyond the plane of the suture. Plasmodia either small (monosporic) to medium-sized, polysporic, in which formation of pansporoblasts occurs. Coelozoic, rarely histozoic, in freshwater and marine fishes, some in amphibians.

Chloromyxum Mingazzini, 1890

Figs. 36, 37

Spore valves smooth or ridged, rarely with caudal filamentous projections. Polar capsules often in two pairs of unequal size. Sporoplasm binucleate, rarely uninucleate. For exact determination of species, one has often to resort to scanning electron microscope. Species composition of the genus is heterogeneous. Chloromyxum species differ in phylogeny as well as in actinospore stages. Neoactinomyxum was found in a freshwater Chloromyxum sp., antonactinomyxon in C. aura- tum (Hallett et al. 2006) and aurantiactinomyxon in C. truttae (Holzer et al. 2004). Number of species: 115, including 3 in amphibians.

References: Listerbarger and Mitchell (1980), Lom and Dyková (1993); phylogeny - Fiala and Dyková (2004).

Type species Chloromyxum leydigi Mingazzini, 1890 (Fig. 36) described originally —without specifying the host - from the gall bladder of various species of a number of sharks and skates of the genera Mustellus, Galeus (syn. Pristiurus), Raja, Scyllium, Squatina, Torpedo and Trygon. A thorough revision will probably show the present $C$. leydigi described from many hosts to be an assemblage of several species, as suggested by Jameson (1929) and Kuznetsova (1977).

Pathogenic species: Chloromyxum cristatum Léger, 1906 (Fig. 37) in the gall bladder of Tinca tinca and other cyprinids; may cause necrosis of the liver parenchyma of Cyprinus carpio (Lom and Dyková 1984). Complete life cycle of this species has been solved by Hallett et al. (2006): myxospores alternate with antonactinomyxon actinospores. C. truttae Léger, 1906 in the gall bladder of Salmo trutta fario, S. salar, Oncorhynchus mykiss and other salmonids (Bauer et al. 1981).

\section{Caudomyxum Bauer, 1948}

Fig. 38

Subspherical spores with smooth valves, each extending into a stout, tapering caudal projection. Plasmodia polysporic with pansporoblast formation. One species was observed in kidneys of freshwater fishes, one in the amphibian Molge cristata. Unpublished data suggest the existence of more species.

Type species Caudomyxum nanum Bauer, 1948 (Fig. 38) described from renal tubules of Lota lota in rivers of the European and Siberian part of the former USSR.

\section{Agarella Dunkerly, 1915}

Fig. 39

Spores elongate ovoid, very slightly flattened parallel to the sutural line. Each valve extends into a caudal projection. Four pyriform polar capsules, of which two are larger with a long, narrow anterior neck and two smaller, shorter ones, with one of each in each shell valve. Histozoic polysporic plasmodia in freshwater fishes.

Type and only species Agarella gracilis Dunkerly, 1915 (Fig. 39) described from the testes of the freshwater fish Lepidosiren paradoxa in Brazil. One unidentified species was found in a Surinam frog.

\section{A u e r b a c h i id a e Evdokimova, 1973}

Spores have asymmetrical unequal smooth shell valves and a single elongated polar capsule with a filament making a few longitudinal turns. Coelozoic, polysporic plasmodia in the gall bladder of marine fishes.

\section{Auerbachia Meglitsch, 1968}

Fig. 40

Spores club-like, with a broad anterior part and a narrow caudal part. The two unequally large shell valves are asymmetrical, dissimilar in form and meet along a curved, very indistinct suture; the larger valve is drawn into a wide caudal projection. Polar capsule opens at the anterior end of the spore. Sporoplasm binucleate. Large polysporic plasmodia. Number of species: 3 .

Type species Auerbachia anomala Meglitsch, 1968 (Fig. 40) in the gall bladder of the deep-sea fish Genypterus blacodes off the coast of New Zealand. 


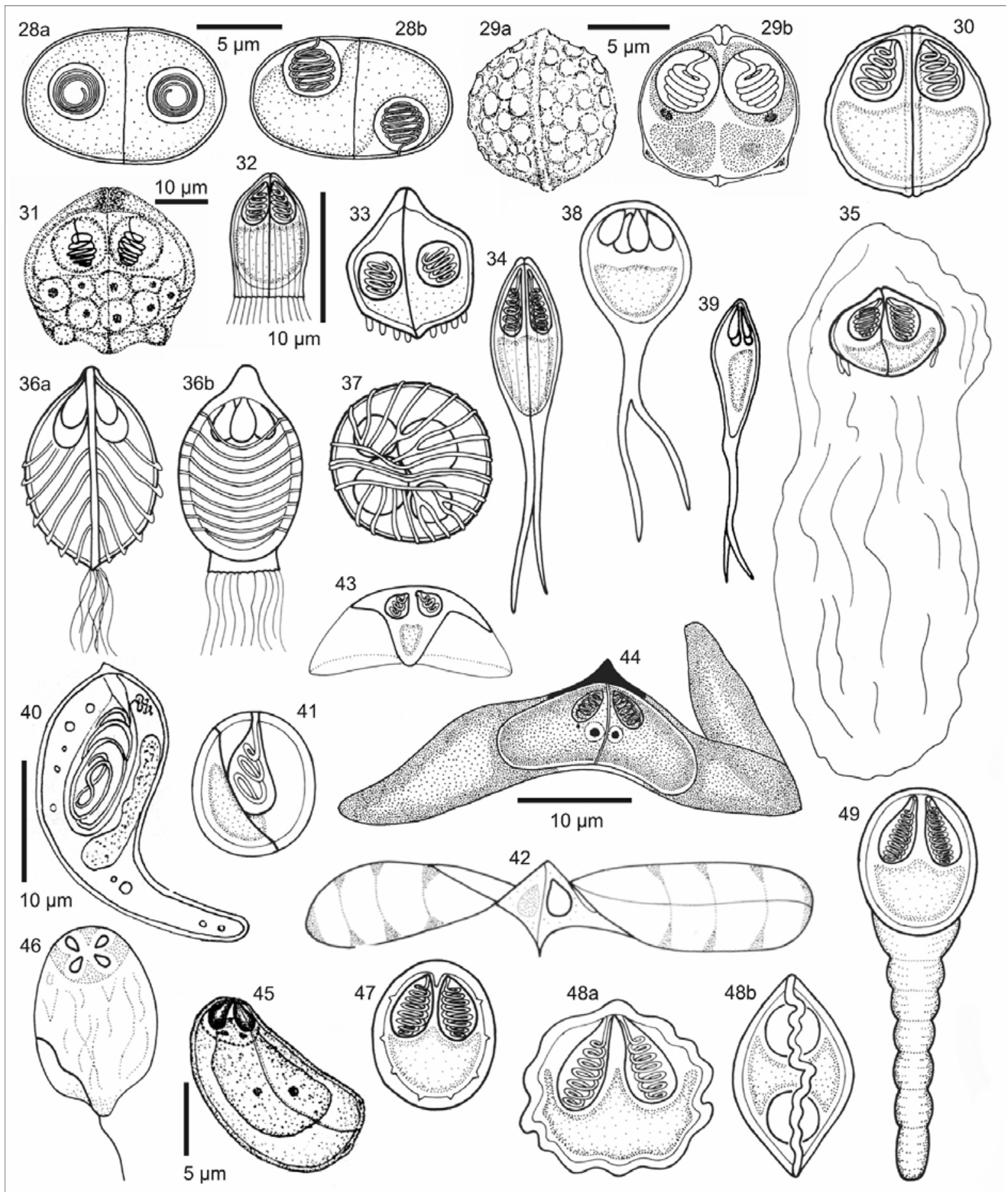

Figs. 28-49. Line drawings of myxosporean spores. Fig. 28. Ellipsomyxa gobii in apical (a) and sutural view (b) (courtesy of M. Køie and Folia Parasitol.). Fig. 29. Sphaerospora elegans, pitted spore surface (a), sutural view (b) (courtesy of Dr. S.W. Feist and Eur. J. Protistol.). Fig. 30. Sphaerospora renicola in sutural view. Fig. 31. Polysporoplasma sparis in sutural view (courtesy of Drs. Sitjà-Bobadilla and Alvarez-Pellitero and Eur. J. Protistol.). Fig. 32. Hoferellus cyprini in sutural view. Fig. 33. Wardia ovinocua. Fig. 34. Myxobilatus gasterostei in sutural view. Fig. 35. Palliatus mirabilis in sutural view. Fig. 36. Chloromyxum leydigi in sutural (a) and frontal view (b). Fig. 37. Chloromyxum cristatum in apical view. Fig. 38. Caudomyxum nanum. Fig. 39. Agarella gracilis. Fig. 40. Auerbachia anomala (from Meglitsch 1968, courtesy of Proc. Iowa Acad. Sci.). Fig. 41. Globospora sphaerica. Fig. 42. Alatospora samaroidea. Fig. 43. Pseudoalatospora scombri. Fig. 44. Renispora simae (courtesy of Dr. C. Kalavati et al. and Syst. Parasitol.). Fig. 45. Parvicapsula asymmetrica (modified from Shulman and Shulman-Albova 1953). Fig. 46. Neoparvicapsula ovalis. Fig. 47. Myxobolus muelleri. Fig. 48. Spirosuturia carassii in frontal (a) and apical view (b). Fig. 49. Unicauda clavicauda. 
Globospora Lom, Noble et Laird, 1975

Fig. 41

Subspherical spores have unequal smooth shell valves meeting along a curved, delicate suture. Capsular opening at some distance from sutural line.

Type and only species Globospora sphaerica (Evdokimova, 1973) Lom, Noble et Laird, 1975 (Fig. 41) lives in Odontesthes incisa (syn. Austroatherina incisa) off Argentina coast. Sporogonic plasmodium was not observed.

\section{A 1 a t o s p o ri d a e Shulman, Kovaleva et Dubina, 1979}

Spores in sutural view shaped like a double isosceles flat triangle. The long tips are set perpendicularly to the central sutural line, short tips are oriented in continuation of the suture. Two polar capsules are set in a plane perpendicular to the suture. Shell valves bear conspicuous wing-like projections. Coelozoic in gall bladder of marine fishes

Alatospora Shulman, Kovaleva et Dubina, 1979

Fig. 42

Spores extremely elongated in plane perpendicular to the central straight suture line. Shell valves bear wing-like membranaceous projections adhering along their posterior half. Polar capsules small. Disporic to polysporic trophozoites in the gall bladder. Number of species: 17 .

Type species Alatospora samaroidea Shulman, Kovaleva et Dubina, 1979 (Fig. 42) in the gall bladder of Chlorophthalmus atlanticus off the Atlantic coast of Africa.

Pseudoalatospora Kovaleva et Gaevskaya, 1983

Fig. 43

Spores similar to Alatospora differ in having their valve projections doubled to form parachute-like pockets. Trophozoites mono- to disporic. Number of species: 12.

Type species Pseudoalatospora scombri Kovaleva et Gaevskaya, 1983 (Fig. 43) was described from the gall bladder of Scomber japonicus from the South-Eastern Pacific.

Renispora Kalavati, Longshaw et MacKenzie, 1996 Fig. 44

Reniform spores have a transverse sutural line. Shell valves have laterally extending alate processes adhering all around the valves. Pyriform polar capsules situated close to sutural line in a plane perpendicular to it. Polysporic plasmodia, coelozoic in gall bladder.

Type and only species Renispora simae Kalavati, Longshaw et MacKenzie, 1996 (Fig. 44) in Patagonotothen sima from the Atlantic Ocean off the Falkland Islands.

\section{P a rvic a p s u lid a e Shulman, 1953}

Spores asymmetrical, thin-walled, elongated roughly in sutural plane. Unequal shell valves meet in a curved suture. Two or four conspicuously small polar capsules in the spore apex. Trophozoites disporic to tetrasporic. Coelozoic in the urinary system or histozoic in marine and anadromous fishes.

\section{Parvicapsula Shulman, 1953}

Fig. 45

Spores elongated, asymmetrical, somewhat curved. Two small pyriform polar capsules located anteriorly but discharge sideways. One relatively large binucleate sporoplasm. Disporic trophozoites coelozoic in the urinary system or histozoic in kidneys. Number of species: 10. A survey of species was published by Køie (2003b).

Type species Parvicapsula asymmetrica Shulman, 1953 (Fig. 45) in the urinary bladder of Cyclopterus lumpus in the White Sea.

Pathogenic species: Parvicapsula minibicornis Kent, Whitaker et Dawe, 1997 may cause severe infections in kid- ney of feral and cultured salmonids of the genus Oncorhynchus at the northern U.S. Pacific coasts (St-Hilaire et al. 2002, Jones et al. 2003). Its morphology differs somehow from that of other species of this genus. It has an actinospore stage, probably a tetractinomyxon, in the coelom of the polychaete Manayunkia speciosa (Bartholomew et al. 2005). P. pseudobranchicola Karlsbakk, Saether, Hostlund, Fjellsoy et Nylund, 2002 infects pseudobranchs of cultured Salmo salar in Norway, causing mortalities (Karlsbakk et al. 2002, Nylund et al. 2005). Probably identical is Parvicapsula sp. infecting pseudobranchs and kidney of Oncorhynchus kisutch in maricultures at the U.S. Pacific coast (Yasutake and Elliot 2003).

Neoparvicapsula Gaevskaya, Kovaleva et Shulman, 1982

The main difference from Parvicapsula is the presence of four small pyriform polar capsules in a cross-like arrangement in the spore apex. Trophozoites di- to tetrasporic, coelozoic in the urinary system of marine fishes. Number of species: 2 .

Type species Neoparvicapsula ovalis Kovaleva, Gaevskaya et Shulman, 1982 (Fig. 46) in the urinary system of Gobionotothen gibberifrons (syn. Notothenia gibberifrons) from the South Atlantic.

\section{SUbORDER Platysporina Kudo, 1919}

Spores as a rule flattened parallel to the sutural plane, bilaterally symmetrical. Generally two, sometimes one polar capsule lies solely in the sutural plane. As a rule, histozoic parasites of freshwater fishes, which produce large polysporic plasmodia; spores - as a rule with hard shells - arise in pansporoblasts. Plasmodia up to several $\mathrm{mm}$ in size are enveloped by the connective tissue of the host and appear like small cysts.

\section{M y x o b o li d a e Thélohan, 1892}

The suture forms an elevated ridge and may be drawn out as long posterior projections. One of the two polar capsules may be smaller or disappear completely. Spores in most species have a spherical polysaccharide inclusion (iodinophilous vacuole) in the sporoplasm.

Myxobolus Bütschli, 1882

Fig. 47

Synonyms: Myxosoma Thélohan, 1892; Lentospora Plehn, 1905; Disparospora Akhmerov, 1954; Facieplatycauda Wyatt, 1979; Rudicapsula Kalavati et Narasimhamurti, 1984

Spores in valvular view ellipsoidal, ovoid or rounded, in sutural view biconvex. Shell valves as a rule smooth. Two polar capsules mostly pyriform, sometimes unequal, exceptionally one seems to be missing. The sutural ridge may extend posteriorly onto a crescentic ledge. Sporoplasm binucleate, often with an iodinophilous vacuole. Trophozoites as a rule large, with formation of numerous pansporoblasts and appear in the tissue-like cysts. Generally histozoic in freshwater fishes. About 30 species live in marine (mostly estuarine) fishes, some of them have coelozoic plasmodia of far less compact structure than histozoic trophozoites (e.g., M. conei Lom et Dyková, 1994). Future research may assign —at least partly - marine and freshwater species to different genera. Many species seem to be host- and tissue-specific, while others have been reported to indiscriminately infect many hosts and various tissues, an issue, which has to be verified. Number of species: 792, including 7 in amphibians.

Description of the monotypic genus Gyrospora Qadri, 1962 is not complete enough to permit a safe differentiation from Myxobolus; it was described as having polar filaments 
with a very thick basal part (Qadri 1962b). Thus far, complete developmental cycles have been described for 14 species. In Myxobolus cerebralis (discovered by Wolf and Markiw 1984), M. cotti (El-Matbouli and Hoffmann 1989), M. carassii (ElMatbouli and Hoffmann 1993), M. arcticus (Kent et al. 1993, Urawa 1994), M. drjagini (El-Mansy and Molnár 1997a), M. portucalensis (El-Mansy et al. 1998), M. hungaricus (ElMansy and Molnár 1997b), M. pseudodispar (Székely et al. 2001), M. bramae (Eszterbauer et al. 2000), M. macrocapsularis (Székely et al. 2002) and M. parviformis (Kallert et al. 2005 b) the actinospore stage is a triactinomyxon. In M. pavlovskii it is hexactinomyxon (Ruidisch et al. 1991), in M. cultus (Yokoyama et al. 1995) and in M. dispar it is raabeia (Molnár et al. 1999a, Holzer et al. 2004). The diversity of actinospore stages confirms the heterogeneity of the genus and should be reflected in its taxonomy in near future. Curiously, M. dispar and M. pavlovskii, with differing actinospore stages, cluster together in SSU rDNA phylograms (Fiala, pers. comm.).

References: list of species - Landsberg and Lom (1991); recent synopsis - Eiras et al. (2005), 49 species are missing in this list; list of North American species - Cone and Raesly (1995); molecular analysis - Cone and Easy (2005); molecular kinship vs. tissue specificity - Eszterbauer (2004).

Type species Myxobolus muelleri Bütschli, 1882 (Fig. 47) originally described from gills and fins of Leuciscus cephalus from Germany. This name probably covers a conglomerate of more species, as evidenced by the great variability of spores, most varied tissues which it was claimed to infect, and especially a great number of hosts (more than 80 can be found in the literature!), mostly cyprinids from the whole Eurasia.

Pathogenic species: Myxobolus acanthogobii Hoshina, 1952 (syn. M. buri Egusa, 1985), parasite of the brain, causes scoliosis of cultured marine fish Seriola quinqueradiata in Japan (Sakaguchi et al. 1987, Yokoyama et al. 2004). M. buckei Longshaw, Frear et Feist, 2003 is highly pathogenic to juvenile cyprinids of the genera Leuciscus, Rutilus and Abramis, in which it destroys the spinal column (Longshaw et al. 2003). M. cerebralis Hofer, 1903, agent of the "whirling disease" of salmonid fry of the genera Hucho, Oncorhynchus, Salmo and Salvelinus, infecting mainly head and gill cartilage, originally probably a mild pathogen of Salmo trutta in Central Europe, it is now globally distributed (Hoffman 1990, ElMatbouli et al. 1995, 1998, 1999, Andree et al. 1997, 2002, Hedrick et al. 1998, Bartholomew and Wilson 2002, Hedrick and El-Matbouli 2002, Gilbert and Granath 2003). M. drjagini (Akhmerov, 1954) in subcutaneous tissue, central nervous system and organs of balance of Hypophthalmichthys molitrix in Asia; it is the agent of epizootics of "twist disease" and mass mortalities in China (Wu et al. 1979). M. encephalicus (Mulsow, 1911) in brain blood vessels of Cyprinus carpio in Europe (Dyková et al. 1986). M. insidiosus Wyatt et Pratt, 1963 in the muscle of North American salmonids of the genera Oncorhynchus and Salmo (Wyatt 1979, Amandi et al. 1985). M. pavlovskii Akhmerov, 1954, common in the gills of Hypophthalmichthys molitrix and Aristichthys nobilis in the Far East Amur region, was imported along with these hosts to Europe (Molnár 1979b). M. sandrae Reuss, 1906 in subcutaneous connective tissue of the head, in branchial cavity, sometimes in the gills of Sander lucioperca (syn. Stizostedion lucioperca) in Europe. In the spinal cord of Perca fluviatilis in Scotland, infections result in severe deformations of the vertebral column (Lom et al. 1991a).

\section{Spirosuturia Chen et Hsieh, 1984}

Fig. 48

Differs from Myxobolus only by a strongly sinuous sutural line, slightly diverging from the plane in which the two polar capsules lie. A molecular revision is warranted. Histozoic in freshwater fish. Number of species: 3 .

Type species Spirosuturia carassii Chen et Hsieh, 1984 (Fig. 48) lives in the wall of the urinary bladder of Carassius auratus in China.

Unicauda Davis, 1944

Spores similar to those of Myxobolus have a single caudal appendage. This, unlike in Henneguya, is no prolongation of the shell valves but a structure made up from different, not yet precisely specified material and adheres to the shell valve along a distinct boundary. Strictly histozoic in freshwater fishes. Twenty-seven species, of which in about 16 is not known whether the appendage really corresponds to the definition of the genus.

Reference: synopsis of the genus - Cone and Melendy (2000).

Type species Unicauda clavicauda (Kudo, 1934) Davis, 1944 (Fig. 49) in subcutaneous tissue of Notropis blennius from Illinois, USA.

Dicauda Hoffman et Walker, 1978

Fig. 50

It differs from Unicauda by two caudal appendages, extending in opposing directions.

Type and only species Dicauda atherinoidi Hoffman et Walker, 1978 (Fig. 50) in subcutaneous tissue of freshwater fish Notropis atherinoides from USA.

Phlogospora Qadri, 1962

Drop-like, flattened spores have a bifurcated caudal process fitted to the posterior end along a distinct boundary. There is a single, elongated polar capsule. Binucleate sporoplasm with polysaccharide reserves in form of a spherical inclusion. Vegetative stages unknown. Number of species: 3.

Type species Phlogospora mysti Qadri, 1962 (Fig. 51) is a histozoic parasite of the gills of freshwater fish Mystus bleekeri from India (Qadri 1962a).

\section{Laterocaudata Chen et Hsieh, 1984}

Fig. 52

Spores similar to those of Myxobolus are ellipsoidal in valvular view and have a long, thin and curved process split at the end. The process originates posteriolaterally from the sutural edge of the valves. Plasmodium was not described.

Type and only species Laterocaudata mastacembala Chen et Hsieh, 1984 (Fig. 52) was described from the gills of freshwater fish Macrognathus aculeatus (syn. Mastacembelus aculeatus) from China.

Henneguya Thélohan, 1892

Fig. 53

Spores ellipsoid, spindle-shaped or rounded in valvular view, biconvex in sutural view. Each valve continues as a caudal projection, both projections may be apposed. Shell valves smooth. Two polar capsules are as a rule very elongated. In the binucleate sporoplasm is usually a spherical polysaccharide inclusion. Polysporic plasmodia with pansporoblast formation usually large, appearing like cysts. Histozoic in freshwater, sometimes marine fishes. Number of species: 204. The assumption of Kent et al. (2001) and Bahri et al. (2003) that Henneguya is an invalid taxon is probably legitimate, since the distinguishing character, the two caudal projections, had probably arisen several times in the evolutionary 
history of Myxobolus. This is supported by many species of both genera clustering together in SSU rDNA phylograms (Yokoyama et al. 2005, Eszterbauer et al. 2005).

References: Minchew (1977), Kent et al. (2001), Eiras (2002 - list of species); fine structure - Lom and de Puytorac (1965b), Schubert (1968).

Complete life cycle is known in three species: in Henneguya exilis the actinospore is an aurantiactinomyxon earlier described as A. janiszewskai (Lin et al. 1999), in H. ictaluri the aurantiactinomyxon was earlier named as $A$. ictaluri (Pote et al. 2000), in H. nuesslini Schuberg et Schröder, 1905 it is a triactinomyxon (Kallert et al. 2005a). In the recent phylogenetic tree (Fiala, pers. comm.), H. exilis clusters separately from two other species mentioned above.

Type species Henneguya psorospermica Thélohan, 1892 (Fig. 53), common parasite in the gills of Esox lucius and Perca fluviatilis, perhaps also Sander lucioperca (syn. Stizostedion lucioperca) in Eurasia (Dyková and Lom 1978).

Pathogenic species: Henneguya exilis Kudo, 1929 in the gills of Ictalurus punctatus in North America. (Current and Janovy 1978, Bowser and Conroy 1985, Duhamel et al. 1986). H. ictaluri Pote, Hanson et Shivaji, 2000, one of the agents of the proliferative gill disease (PGD, also hamburger disease) of Ictalurus punctatus in North America (Pote et al. 2000, Bolem and Pote 2001). H. lateolabracis Yokoyama, Kawakami, Yasuda et Tanaka, 2003 causes cardiac henneguyosis with chronic mortalities in cultured Lateolabrax sp. in Japan (Yokoyama et al. 2003). H. pagri Yokoyama, Itoh et Tanaka, 2005 infects bulbus arteriosus of the heart of cultured Pagrus major in Japan, causing degenerative cardiomyopathy and chronic mortalities (Yokoyama et al. 2005). H. zschokkei Gurley, 1894 [probable synonyms are H. salminicola Ward, 1919 and $H$. tegidiensis Nicholas et Jones, 1959; possibly also $H$. kolesnikovi (Gurley, 1894) Labbé, 1899] in muscles of several species of the genus Coregonus in Europe and five species of the Pacific salmon common to North American and Asian coasts - Oncorhynchus gorbuscha, O. keta, O. kisutch, O. nerka, O. tshawytscha and O. mykiss (Awakura and Kimura 1977, Boyce et al. 1985).

Hennegoides Lom, Tonguthai et Dyková, 1991

Fig. 54

Unlike Henneguya the spores are asymmetrical with nonaxially attached caudal appendages. Polar filament anisofilar, wound longitudinally in the polar capsules. Polysporic, without pansporoblast formation. Number of species: 4 .

Type species Hennegoides longitudinalis Lom, Tonguthai et Dyková, 1991 (Fig. 54) infects subepithelial layer in the intestine of cultured Osphronemus goramy in Thailand (Lom et al. 1991b).

Tetrauronema Wu, Wang et Jiang, 1988

Fig. 55

Spores resemble those of Myxobolus, are posteriorly tapered and bear four thin, symmetrically arranged projections, one inserted at each side of the shell valve near the posterior end. Histozoic in freshwater fishes. Number of species: 2.

Reference: Azevedo and Matos (1996).

Type species Tetrauronema macropodus Wu, Wang et Jiang, 1988 (Fig. 55) in gill filaments of Macropodus opercularis (syn. M. chinensis) in Fujian province, China.

Thelohanellus Kudo, 1933

Figs. 56, 57

Spores tear-shaped, pyriform to broadly ellipsoidal in valvular view, being more slender in sutural view. Always with smooth valves. A single polar capsule, either pyriform, tear- shaped with a single coil of polar filament, or subspherical with a second, inner coil. Thus the genus might well be split in two according to differences in spore morphology. Species of the genus Myxobolus with one capsule extremely stunted indicate the possible closeness of both genera, also suggested in some phylograms (Fiala, pers. comm.). Sporoplasm binucleate, mostly with a spherical polysaccharide inclusion. Polysporous plasmodia with pansporoblast formation are mostly large. Histozoic parasites of freshwater fishes. Number of species: 75 .

The complete life cycle is known in two species: in both $T$. hovorkai and T. nikolskii, aurantiactinomyxon stages occur (Yokoyama 1997 and Székely et al. 1998, respectively).

Type species Thelohanellus pyriformis (Thélohan, 1892) Kudo, 1933 (Fig. 56) was described from blood vessels of gills, spleen and kidney of Tinca tinca; also occurs in Rutilus rutilus, Abramis brama and some other cyprinids (Sołtynska 1967, Dyková and Lom 1987).

In Thelohanellus jiroveci Kundu et Haldar, 1981 from the gills of Labeo bata in India were reported macro- and microspores in the same plasmodium, a unique feature in myxosporea.

Pathogenic species: Thelohanellus hovorkai Akhmerov, 1960 (Fig. 57), common in Cyprinus carpio of up to two years of age in Eurasia, forming plasmodia of up to $3 \mathrm{~mm}$ in size in connective tissue of various organs (digestive tract, kidney, swimbladder, subcutis and even brain); agent of haemorrhagic thelohanellosis (Molnár and Kovacs-Gayer 1986a, Yokoyama et al. 1998 Liyanage et al. 2003). T. kitauei Egusa et Nakajima, 1981 produces giant plasmodia in submucosa of the intestine of common carp in Japan (Rhee et al. 1990). T. nikolskii Akhmerov, 1954 (syn. T. cyprini Hoshina et Hoshoda, 1957) common in carp (Cyprinus carpio) fingerlings in Eurasia. Rounded, cyst-like plasmodia up to $2 \mathrm{~mm}$ in size appear as bunch-of-grape-like structures on the fins, developing in close associations with cartilaginous fin rays. The relation of $T$. hovorkai and T. nikolskii warrants revision.

References: Molnár (1982), Desser et al. (1983), Székely et al. (1998).

Neothelohanellus Das et Haldar, 1986

Synonym: Lomosporus Gupta et Khera, 1988

Fig. 58

Spores in frontal view oval or egg-shaped with a wider anterior end; longitudinal suture line. A single elliptical polar capsule at the anterior end opens laterally or subapically. Large polysporous plasmodia. Histozoic in freshwater fish. The genus does not differ essentially from Thelohanellus and careful analysis may show it to be a synonym of Thelohanellus. Number of species: 3.

Type species Neothelohanellus catlae Das et Haldar, 1986 (Fig. 58) in kidney tissue of the freshwater fish Catla catla in West Bengal, India.

Neohenneguya Tripathi, 1953

Fig. 59

Spores spindle-shaped in valvular view and flattened spindle-shaped in sutural view. Two fine, equal prolongations attach to the shell both at anterior and posterior end. Two spherical polar capsules are in tandem position, at some distance from the anterior end. Large polysporic plasmodia histozoic in freshwater fishes.

Type and only species Neohenneguya tetraradiata Tripathi, 1953 (Fig. 59) is histozoic in the gills of Odontamblyopus rubicundus in India. 


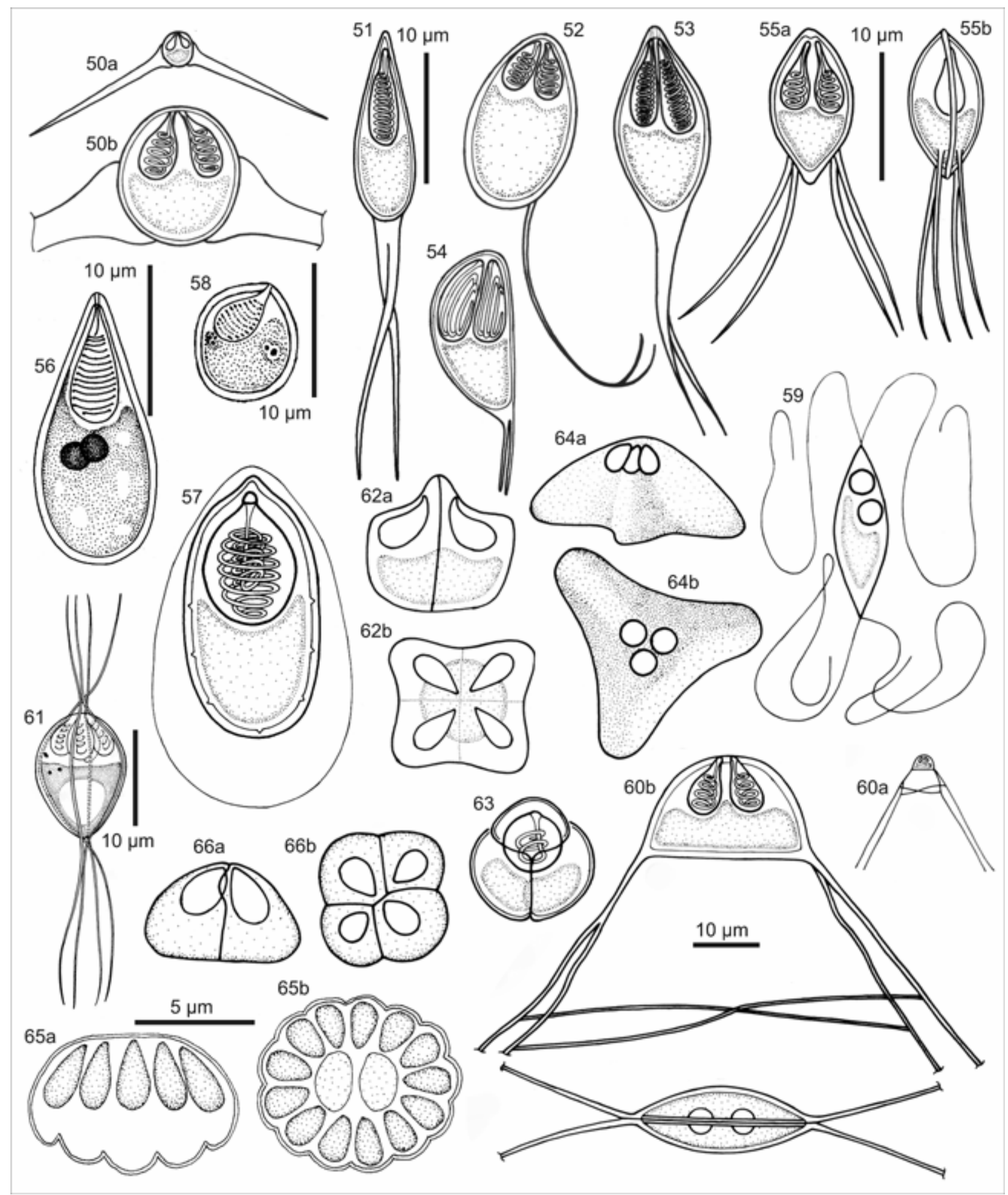

Figs. 50-66. Line drawings of myxosporean spores. Fig. 50. Dicauda atherinoidi, aspect of the whole spore (a), spore body in frontal view (b). Fig. 51. Phlogospora mysti. Fig. 52. Laterocaudata mastacembala. Fig. 53. Henneguya psorospermica. Fig. 54. Hennegoides longitudinalis. Fig. 55. Tetrauronema macropodes in frontal (a) and sutural view (b). Fig. 56. Thelohanellus pyriformis (modified from Sołtynska 1967). Fig. 57. Thelohanellus hovorkai. Fig. 58. Neothelohanellus catlae (modified from Das and Haldar 1986). Fig. 59. Neohenneguya tetraradiata. Fig. 60. Trigonosporus acanthogobii. Fig. 61. Octospina tongrensis (modified from Hsieh and Xiao 1993). Fig. 62. Trilospora californica in side (a) and apical view (b). Fig. 63. Unicapsula seriolae. Fig. 64. Kudoa clupeidae in side (a) and apical view (b). Fig. 65. Kudoa permulticapsula in side (a) and apical view (b) (courtesy of Dr. M.L. Kent and J. Parasitol.). Fig. 66. Kudoa paniformis in side (a) and apical view (b). 
Spores broadly triangular, with rounded anterior and flattened posterior ends. Each shell valve is drawn out into two long filamentous processes on each side, each pair being connected by a filament. Two pyriform polar capsules, binucleate sporoplasm has a spherical polysaccharide inclusion. Polysporic plasmodia, histozoic in marine fishes. Number of species: 3 .

Type species Trigonosporus acanthogobii Hoshina, 1952 (Fig. 60) in subepithelial tissue of the gills of Acanthogobius flavimanus (a marine fish that also lives in brackish and freshwater environment) from the coast of Japan.

\section{ORDer MultivalvUlida Shulman, 1959}

Spores are radially symmetrical, posterior face is flat or semispherical, the shell consists of three to seven shell valves; the suture lines are often indistinct. Polar capsules are situated at the apex of spores, their tips are covered by the shell valve and they discharge apically. Their number corresponds to the number of valves. Plasmodia as a rule intracellular in the muscle tissue of marine fishes; pansporoblast formation has not been observed. No actinospore stages have been observed thus far.

References: Kovaleva and Shulman (1978), Egusa (1986).

Whipps et al. (2003) described a multivalvulid species with 13 polar capsules as Kudoa permulticapsula, based on SSU rDNA sequence analysis. This resulted in the requirement to change the diagnosis of Kudoa and, eventually, classification of multivalvulids in general, which was proposed by Whipps et al. (2004). In their phylogenetic analysis of SSU and LSU rDNA, members of the genera Pentacapsula, Hexacapsula and Septemcapsula rooted within the clade of Kudoa species, with Unicapsula as an outliner to these genera. They proposed an altered diagnosis of the family Kudoidae. The genus $\mathrm{Ku}$ $d o a$, the only one within the family Kudoidae Meglitsch, 1960, would accommodate all marine myxosporeans with four or more shell valves and polar capsules ${ }^{1}$. However, the results of Whipps et al. (2004) are important and in this paper they are used in support of demise of the families Pentacapsulidae, Hexacapsulidae and Septemcapsulidae, leaving the order Multivalvulida Shulman, 1959 only with the families Trilosporidae and Kudoidae. However, although reasoning of Whipps et al. (2004) seems convincing, it may be preferable to preserve the existing genera pending future research in molecular analysis, biology and structure which will accumulate decisive data.

\section{Tri lo s p orid a e Shulman, 1959}

Spore with three polar capsules and three shell valves, appearing in apical view as a triradiate star with rounded points. Sporoplasm in the central cavity of the spore. Trophozoites mono- and disporic, in gall bladder or in muscle of marine fishes.

With characters of the family. Number of species: 4 .

Type species Trilospora californica Noble, 1939 (Fig. 62) was described from the gall bladder of marine fishes Gibbonsia elegans and Typhlogobius californiensis from California waters.

Pathogenic species: Trilospora muscularis Priebe, 1987 in the muscle of Molva dypterygia in the North Atlantic (Priebe 1987).

Unicapsula Davis, 1924

Fig. 63

Synonyms: Pileispora Naidenova et Zaika, 1970; Parapileispora Naidenova et Zaika, 1970, pro parte

Spores subspherical, with three unequal shell valves. The small one covers a single spherical polar capsule, while two larger valves, arranged symmetrically contain each a capsular rudiment only discernible by electron microscopy, and two uninucleate sporoplasms, one enveloping the other. In marine fishes. Large polysporic plasmodia in muscles or, in one species, gill filaments. Number of species: 8 .

References: fine structure - Schubert et al. (1975), Lester (1982).

Type species Unicapsula muscularis Davis, 1924; spores closely similar to $U$. seriolae. Plasmodia appear as worm-like structures in muscle fibres of Pacific halibut, Hippoglossus stenolepis, from the North-East Pacific; it is the agent of "wormy halibut".

Pathogenic species: Unicapsula seriolae Lester, 1982 (Fig. 63 ) in muscles of Seriola lalandi along the Australian coast.

\section{K u d o id a e Meglitsch, 1960}

Spores with four shell valves and four polar capsules; two sporoplasm cells, one inside the other.

Kudoa Meglitsch, 1947 Figs. 64-66

Synonyms: Neochloromyxum Matsumoto, 1954; Tetraspina Xie et Chen, 1988

Spores in apical view stellate, quadrate or rounded quadrate; sometimes they are asymmetrical with one valve bigger than the others. Polar capsules pyriform. Two uninucleate sporoplasms, one enveloping the other. Trophozoites small, producing one to seven spores, or large, producing many spores. Parasites of marine fishes; most species are intracellular in muscle cells, exceptionally they infect tissues other than muscles or are coelozoic. Typical parasites of cultured marine fishes (e.g., Egusa and Shiomitsu 1983). Number of species: 63.

References: Kovaleva et al. (1979), Moran et al. (1999a); recent list of species - Swearer and Robertson (1999).

Type species Kudoa clupeidae (Hahn, 1917) Meglitsch, 1947 (Fig. 64) described from Clupea harengus (also infects Alosa pseudoharengus and two more clupeids) from the Atlantic Ocean. In young $C$. harengus, heavy infections may induce mortalities. Lesions in Brevoortia tyrannus were studied by Reimschuessel et al. (2003).

\footnotetext{
${ }^{1}$ Whipps et al. (2004) discussed thoroughly their results and options they offered: either leave the classification as it was - but they thought the revision was appropriate; or introduce subgenera which they did not want since by far not all Kudoa species have been sequenced and thus could not be assigned. So they chose the third, more radical option to reclassify multivalvulids with four or more shell valves as Kudoa species. As one of their supporting arguments they took comparison of genetic distances: maximum distance between any pair of multivalvulid species was $15.9 \%$, while e.g., maximum distance observed within Myxobolus spp. was 31.1\%. However, it is quite feasible (see above) that the latter genus will be split into separate genera. Also, according to Fiala (pers. comm.), "the monophyly" of multivalvulids has been disturbed by two Sphaerospora species, clustered within the Kudoa clade.
} 
Kudoa permulticapsula Whipps, Adlard, Bryant et Kent, 2003 (Fig. 65), an unusual Kudoa species with 13, sometimes 14 or even 15 polar capsules arranged in a ring, often with 1 or 2 additional capsules located centrally. The reason why it was assigned to Kudoa and not to a new genus is that the neighbour-joining analysis of SSU rDNA placed it within a $K u d o a$ clade, with close relation to K. thyrsites and K. quadricornis. If the view of Whipps et al. (2003) is accepted, it will be the first case when in myxozoan taxonomy molecular analysis prevailed over spore morphology. It is left in the genus Kudoa until final solution of the classification. It lives in somatic muscle of Scomberomorus commerson from the Great Barrier Reef off Australia.

Pathogenic species eliciting mushy flesh or myoliquefaction: Kudoa histolytica (Pérard, 1928) Meglitsch, 1960 in the mackerel Scomber scombrus in the Atlantic Ocean and the Mediterranean Sea (Shukgalter 2004, Hoffmann 2005). K. megacapsula Yokoyama et Itoh, 2005 in the food fish red barracuda Sphyraena pinguis from the China Sea (Yokohama and Itoh 2005). K. musculoliquefaciens (Matsumoto et Arai, 1954) Meglitsch, 1960 in the swordfish Xiphias gladius from the Pacific coast of Japan (Matsumoto and Arai 1954). K. paniformis Kabata et Whitaker, 1981 (Fig. 66) is a deleterious parasite of the Pacific hake, Merluccius productus, in which the total prevalence, single or in infections mixed with $K$. thyrsites, is up to $90 \%$ (Kabata and Whitaker 1981, Patashnik et al. 1982). K. thyrsites (Gilchrist, 1924) Meglitsch, 1960 described from Thyrsites atun off South African coast has been known now as a cosmopolitan parasite infecting many species of marine fishes, such as Pacific hake, Merluccius productus, and including salmonids, such as Salmo salar and Oncorhynchus kisutch (Stehr and Whitaker 1986, Whitaker and Kent 1991, Moran et al. 1999b).

Species damaging the muscle tissue by proliferation of a mass of trophozoites: Kudoa amamiensis Egusa et Nakajima, 1978 in cultured Seriola quinqueradiata in Japan (Egusa and Nakajima 1978).

A unique, non-piscine Kudoa sp. was found to cause postmortem myoliquefaction of arm muscles in the cephalopod Paroctopus dofleini in the North Pacific (Yokoyama and Masuda 2001).

\section{Pentacapsula Naidenova et Zaika, 1970}

Fig. 67

Spores in apical view stellate, pentaradiate, in frontal view they appear flat conical. There is a polar capsule to each valve. Histozoic parasites of marine fishes. Number of species: 4 .

Type species Pentacapsula shulmani Naidenova et Zaika, 1970 (Fig. 67) in skeletal muscles of Nemipterus japonicus from the Pacific.

Pathogenic species: Pentacapsula neurophila Grossel, Dyková, Handlinger et Munday, 2003 causes severe granulomatous encephalomyelitis in cultured Latris lineata in Tasmanian waters (Grossel et al. 2003).

\section{Hexacapsula Arai et Matsumoto, 1953}

Fig. 68

Spores have six polar capsules and six shell valves. Parasites in muscles of marine fishes.

Type and only species Hexacapsula neothunni Arai et Matsumoto, 1953 (Fig. 68) develops in skeletal muscles of marine fish Thunnus albacares (syn. Neothunnus macropterus) from seas around Japan. No data on sporogonic plasmodia were given. The parasite induces "jellied condition" of the flesh (Arai et Matsumoto 1953). Such fish are unmarketable.

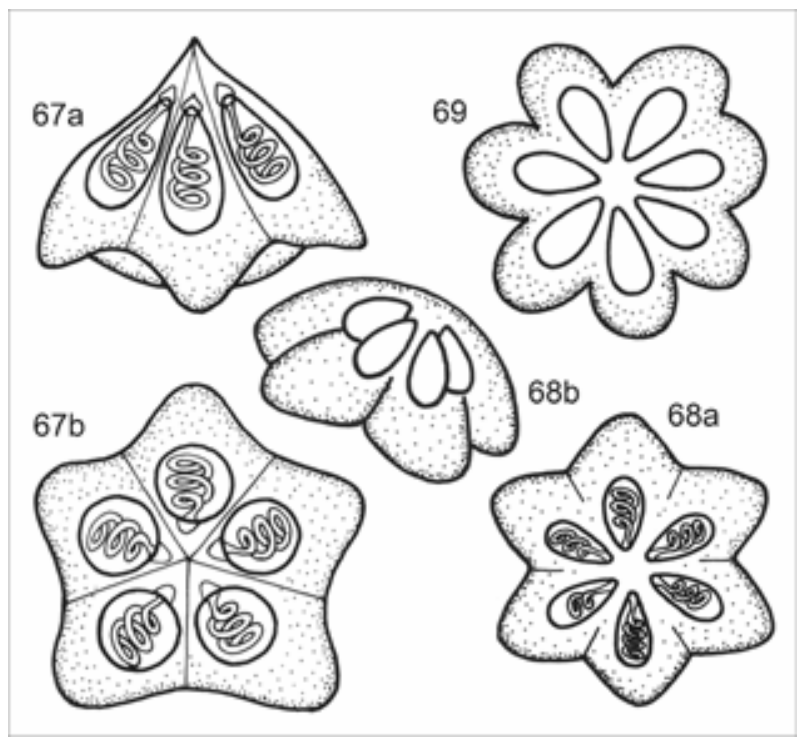

Fig. 67-69. Line drawings of myxosporean spores. Fig. 67. Pentacapsula shulmani in side (a) and apical view (b). Fig. 68. Hexacapsula neothunni in side (a) and apical view (b). Fig. 69. Septemcapsula yasunagai in apical view. Figs. 68-70, 7280 and 82 are reproduced through courtesy of Dr. A. Marques from his thesis (Marques 1984).

\section{Septemcapsula Hsieh et Chen, 1984}

Fig. 69

Multivalvulids with seven shell valves, each containing one polar capsule, parasitic in muscles of marine fishes.

Type and only species Septemcapsula yasunagai Hsieh et Chen, 1984 (Fig. 69) is a pathogen in brain cavity of cultured marine fishes Lateolabrax japonicus and Oplegnathus fasciatus in China. No data on sporogonic plasmodia were given.

As an appendix to multivalvulids, two organisms are added which, in spite of having three and four shell valves and reminding in this respect of this order, do not comply with its definition.

\section{Trilosporoides Køie, 2005}

Fig. 85

Køie (2005b) described a myxosporean, which she placed temporarily in the vicinity of the family Trilosporidae Shulman, 1959 because of spores equipped with three polar capsules. However, the polar capsules are situated peripherally and discharge laterally, the spore has a long conical posterior end and tips of polar capsules protruding through the shell valve unlike most myxosporeans and much alike actinospore stages. This is strongly at variance with Trilosporidae and therefore one has to consider Trilosporoides to be of incertae sedis in Multivalvulida.

Type and only species Trilosporoides platessae Køie, 2005 (Fig. 85) infects the gall bladder of Pleuronectes platessa from the sea off Helsingør, Denmark. The spores were $24 \mu \mathrm{m}$ long and only $9 \mu \mathrm{m}$ in diameter. Plasmodia were not described.

\section{S p in a v a c u li d a e Hsieh et Xiao, 1993}

Spores stout, spindle-shaped, with four identical valves; the sutural ridge of each of them extends anteriad and posteriad as a spine for a distance equalling spore length. Four polar capsules at the anterior pole. In body cavities of freshwater fishes. The position within multivalvulids is preliminary and may be artificial since spores of the only genus are built according to a 
plan quite different from that of other multivalvulids. Hsieh and Xiao (1993) established this family for the genus Octospina and then suggested tentatively a new order Tetravalvulida to accommodate it, which of course would also include Kudoa. This order was then proposed by $\mathrm{Chen}, \mathrm{Ma}, \mathrm{Wu}$ and Lei in the book of Chen and Ma (1998). Until future revision, Octospina has to be regarded as incertae sedis.

Octospina Hsieh et Xiao, 1993

Fig. 61

With characters of the family, sporoplasm with an iodinophilous vacuole.

Type and only species Octospina tongrensis Hsieh et Xiao, 1993 (Fig. 61) attached to swimbladder and gall bladder walls and floating in the bile of Ctenopharyngodon idella in China. Plasmodia were not described.

\section{ACTINOSPORE STAGES AND THEIR DIVERSITY}

Thirteen zoological genera and 44 species of actinospores were described until 1984, when these organisms were still considered to constitute a separate class Actinosporea. Recently, some 136 new types of actinospore collective groups have been described and two genera and four types were still established as independent zoological categories. The counts given for separate collective groups below include only described types; in addition, many types were only mentioned without any description. Experimental infections identified 33 actinospore types as developmental stages of determined myxosporeans. It is up to further research to assign the other types to their fish-infecting myxospore stages.

Since actinospores are nothing more than sexual developmental stages in myxosporean life cycles (Wolf and Markiw 1984), it is not possible to consider them as independent genera and species. They should be named only in the vernacular, using the former genera as collective group names, i.e., a finding should be termed e.g., actinospore triactinomyxon stage, type 2 of Smith 1999 (Kent et al. 1994a, 2001, Lom et al. 1997a, Kent and Lom 1999). One can assume that the development of actinospores into myxospores is a general rule; the direct fish-to-fish transmission can only be taken as a unique exception. A recent finding suggests that also marine myxosporeans may have actinospore stages (Køie et al. 2004). Consequently, also former actinospore genera of which no myxospore counterpart has yet been found can be taken as developmental stages (e.g., Guyenotia, Ormieractinomyxon). Moreover, even the recently erected actinospore genera (Endocapsa, Tetraspora) should be taken for such collective groups and treated as vernacular names. It is possible that they belong to an already described myxosporean with a nomenclatural priority. In the case that they would be associated with a myxospore of a still undescribed myxosporean species, a petition would have to be placed with the International Commission on Zoological Nomenclature to waive their nomenclatural priority to avoid havoc in the existing taxonomy.

Actinospore stages have spores with triradiate symmetry. Their spores develop in groups of eight within a pansporocyst except for tetraspora, in which groups of four develop in the pansporocyst. The stages are classified according to spore morphology; developmental phases have not been reported to have reliable differentiating features. However, spore morphology may be fallacious; Hallett et al. (2002) proved that a single aurantiactinomyxon genotype might have different phenotypes. In addition, reliability of morphometric data in establishing separate spore types was put in doubt by Hallett et al. (2004). The vast discrepancy between the huge number of myxosporean species and of the relatively few actinospore types lead Longshaw and Feist (2005) to propose that actinospore morphology may be a function of the environment and that each actinospore type will not necessarily have a specific corresponding myxospore stage.

In view of the general agreement with the proposal of Kent et al. (1994a) to abolish the class Actinosporea, different actinospore collective groups are listed alphabetically, irrespective of the generic system proposed by Janiszewska (1955, 1957) and Marques (1984). The authority is given to each group. Characters important in describing actinospore stages are given in Lom et al. (1997a).

In individual forms of actinospore stages listed below, the first number indicates number of findings described earlier as a regular zoological species (RZS), the second refers to proven or putative myxospore developmental stages (DS).

Antonactinomyxon Janiszewska, 1957

Fig. 70

Ellipsoidal spore body with protruding tips of polar capsules and a plasmodial sporoplasm with many infectious cells. The valves do not form any style below the spore body and extend into caudal projections diverging from each other, which with their thickened ends contact the ends of caudal projections of other spores. Thus a three-dimensional, cubelike group of all eight spores of the pansporocyst is formed. In freshwater oligochaetes; known as developmental stage of the life cycle of Chloromyxum auratum. Original type Antonactinomyxon antonii 1957 (syn. Siedleckiella antonii Janiszewska, 1954) described from freshwater oligochaete Limnodrilus claparedeanus, from the Oder River at Wroclaw, Poland.

RZS: 1, DS: 2.

Aurantiactinomyxon Janiszewska, 1952

Fig. 71

Three stout, semicircularly curved, leaf-like caudal projections are attached to an ellipsoidal spore body with protruding tips of polar capsules and a plasmodial sporoplasm with many infectious cells. In freshwater oligochaetes. Known as developmental stage in the life cycle of species of the genera Henneguya, Hoferellus, Thelohanellus, Myxidium and Chloromyxum. Original type Aurantiactinomyxon raabeiiunioris Janiszewska, 1952 described from freshwater oligochaete Limnodrilus hoffmeisteri from southern Carpathians, Poland. RZS: 6, DS: 28.

Echinactinomyxon Janiszewska, 1957

Fig. 72

An ovoid spore body with slightly protruding polar capsules and a plasmodial sporoplasm with many infectious cells has mutually divergent straight caudal projections, tapering to sharp tips. In freshwater oligochaetes; known as developmen- 


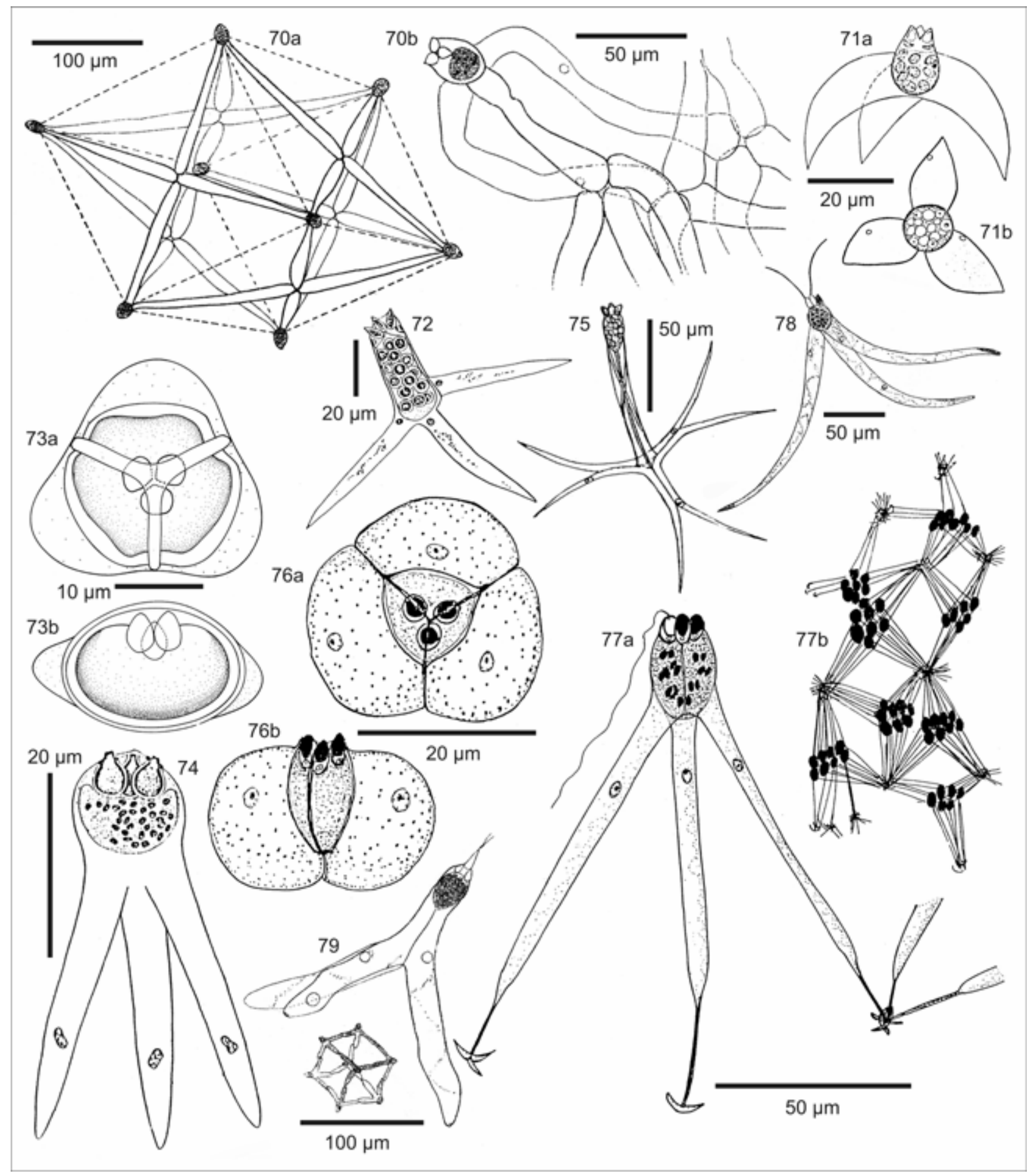

Figs. 70-79. Spores of actinosporean stages. Fig. 70. Antonactinomyxon (type antonii Janiszewska, 1955-57), a group of eight spores (a), spore with its thick caudal projections (b). Fig. 71. Aurantiactinomyxon (type raabeiiunioris Janiszewska, 1957) in side (a) and apical view (b). Fig. 72. Echinactinomyxon (type radiatum Janiszewska, 1957). Fig. 73. Endocapsa (type rossulata Hallett, Erséus et Lester, 1999) in apical (a) and side view (b) (courtesy of Dr. S.L. Hallett and Syst. Parasitol.). Fig. 74. Guyenotia (type sphaerulosa Naville, 1930). Fig. 75. Hexactinomyxon (type psammoryctis Štolc, 1899). Fig. 76. Neoactinomyxum (type globosum Granata, 1922), in apical (a) and side view (b). Fig. 77. Ormieractinomyxon (type racemosum Marques, 1984), single spore (a), spores interconnected to form a large mass (b). Fig. 78. Raabeia (type magna Janiszewska, 1957). Fig. 79. Siedleckiella (type silesica Janiszewska, 1952), single spore (top), group of eight spores from one pansporocyst (bottom). 
tal stage of Sphaerospora truttae and Zschokkella sp. Original type Echinactinomyxon radiatum Janiszewska, 1957 described from freshwater oligochaete Tubifex tubifex from the Oder River, Poland.

RZS: 4, DS: 15 .

Endocapsa Hallett, Erséus et Lester, 1999

Fig. 73

Subspherical spore slightly flattened in the anterio-posterior axis, polar capsules are "embedded" below the spore surface. Valve processes reduced to bulge-like swellings. No data supplied on the sporoplasm. In marine tubificids. Thus far not known as developmental stage in the life cycle of any myxosporean. Original type Endocapsa rosulata Hallett, Erséus et Lester, 1999 described from marine oligochaete Heterodrilus cf. keenani from Great Barrier Reef off Australia.

RZS: 2, DS: 0

Guyenotia Naville, 1930

Fig. 74

The subspherical spore body with polar capsules and a cupshaped plasmodial sporoplasm with many infectious cells. Three stout, slightly divergent and bluntly tipped caudal projections. Not known as developmental stage in the life cycle of any myxosporean. Original and only type G. sphaerulosa Naville, 1930 described from freshwater oligochaete Tubifex tubifex from the Calvados region in France.

RZS: 1, DS: 0.

\section{Hexactinomyxon Štolc, 1899}

Fig. 75

Elongated spore body, with protruding tips of polar capsules and sporoplasm plasmodium with many infectious cells. The shell valves continue posteriorly as a common style, then they diverge, each one being split into two sharp-tipped projections. In some types, the projections have subsidiary protrusions. In freshwater oligochaetes. Known as developmental stage in the life cycle of Myxobolus pavlovskii. Original type Hexactinomyxon psammoryctis Štolc, 1899 described from freshwater oligochaete Psammoryctis barbatus from the Vltava River in Prague, Czech Republic.

RZS: 2, DS: 6.

Hungactinomyxon Rácz, Eszterbauer et Molnár, 2005

Fig. 86

Subspherical spore body similar to echinactinomyxon, with three finger-like, lateroposterior caudal projections of equal size. Their tapered ends are fastened to projection ends of two other spores, so that four spores form a cube-like structure interlaced with another cube made up also of four spores. Thus the eight spores of a pansporocyst form a double cube floating in water. No details on the sporoplasm were provided. Original and only type described from the freshwater oligochaete Branchiura sowerbyi from Száshalombatta, Hungary.

RZS: 0, DS: 1.

Neoactinomyxum Granata, 1922

Fig. 76

Subspherical spore without caudal projections, with prominent apex and anteriorly protruding tips of polar capsules. Plasmodial sporoplasm with many infectious cells. Spore valves extend to rounded triangular flaps, making the spore to appear rounded triangular in apical view. In freshwater oligochaetes. Known as developmental stage in the life cycle of Hoferellus carassii and Chloromyxum sp. Original type Neoactinomyxum globosum Granata, 1922 described from freshwater oligochaete Limnodrilus udekemianus from the Mugove River, Florence, Italy.

RZS: 4, DS: 14
Ormieractinomyxon Marques, 1984

Fig. 77

Similar to echinactinomyxon; the spore body contains a sporoplasm with 16 nuclei (infectious cells?). Long caudal projections taper to a thin rod, at the end of which are small anchor-like structures by means of which the eight spores released from a pansporocyst adhere together. In addition, groups of spores from several pansporocysts also join together to form chains up to several $\mathrm{cm}$ long. Not known as developmental stage in the life cycle of any myxosporean. Original type Ormieractinomyxon racemosum Marques, 1984 described from the freshwater oligochaete Tubifex sp. from the Plaine de Rousillon, France.

RZS: 1, DS: 0.

Pseudotriactinomyxon Hallett, Atkinson, Schöl et ElMatbouli, 2003

Fig. 87

The caudal processes have a prominent longitudinal, axial suture starting already at the base of the spore, like in hexactinomyxon, but unlike it, the processes remain fused longitudinally all their length through, they do not separate in midlength into two halves. Thus the spore has a triactinomyxonlike appearance. Found in filtrates of water containing freshwater oligochaetes. Original type not determined.

RZS: 0, DS: 3.

Raabeia Janiszewska, 1955

Fig. 78

An ellipsoidal spore body with protruding tips of polar capsules and plasmodial sporoplasm; caudal projections divergent, long, sharp-tipped and upward curved. In freshwater oligochaetes. Known as developmental phase in the life cycle of Myxobolus dispar and Myxidium truttae. Original type Raabeia gorlicensis Janiszewska, 1955 described from freshwater oligochaete Tubifex tubifex from Carpathian rivers in Poland.

RZS: 3, DS: 22.

Siedleckiella Janiszewska, 1953

Fig. 79

Spores similar to those of triactinomyxon with a style beneath the spore body. Sporoplasm with about 100 nuclei (of infectious cells?). Caudal projections long and tapering, attach to projections of other spores from the same pansporocyst. This results in a mesh in which all spores are joint between them; this mesh may be irregular or in form of a cube. Known as developmental phase in the life cycle of Zschokkella nova. In freshwater oligochaetes. Original type Siedleckiella silesica Janiszewska, 1952 described from freshwater oligochaete Tubifex sp. near the Oder River at Wroclaw, Poland.

RZS: 1, DS: 2.

Sphaeractinomyxon Caullery et Mesnil, 1904

Fig. 80

Subsphaerical spores without projections of shell valves; polar capsules at the spore apex are "embedded" beneath the spore surface. Plasmodial sporoplasm with many infectious cells. In freshwater and marine oligochaetes. Not known as developmental stage in the life cycle of any myxosporean. Original type Sphaeractinomyxon stolci Caullery et Mesnil, 1904 described from marine oligochaete species of genera $\mathrm{Cli}$ tellio, Peloscolex and Tubifex at the Atlantic coast of France.

RZS: 8, DS: 0

Synactinomyxon Štolc, 1899

Fig. 81

Spores with uneven shell valve projections which extend in the same plane: one is short and conical, extending in a direction opposite to the remaining two broadly-based and sharplytipped projections which run parallel to each other. Sporo- 


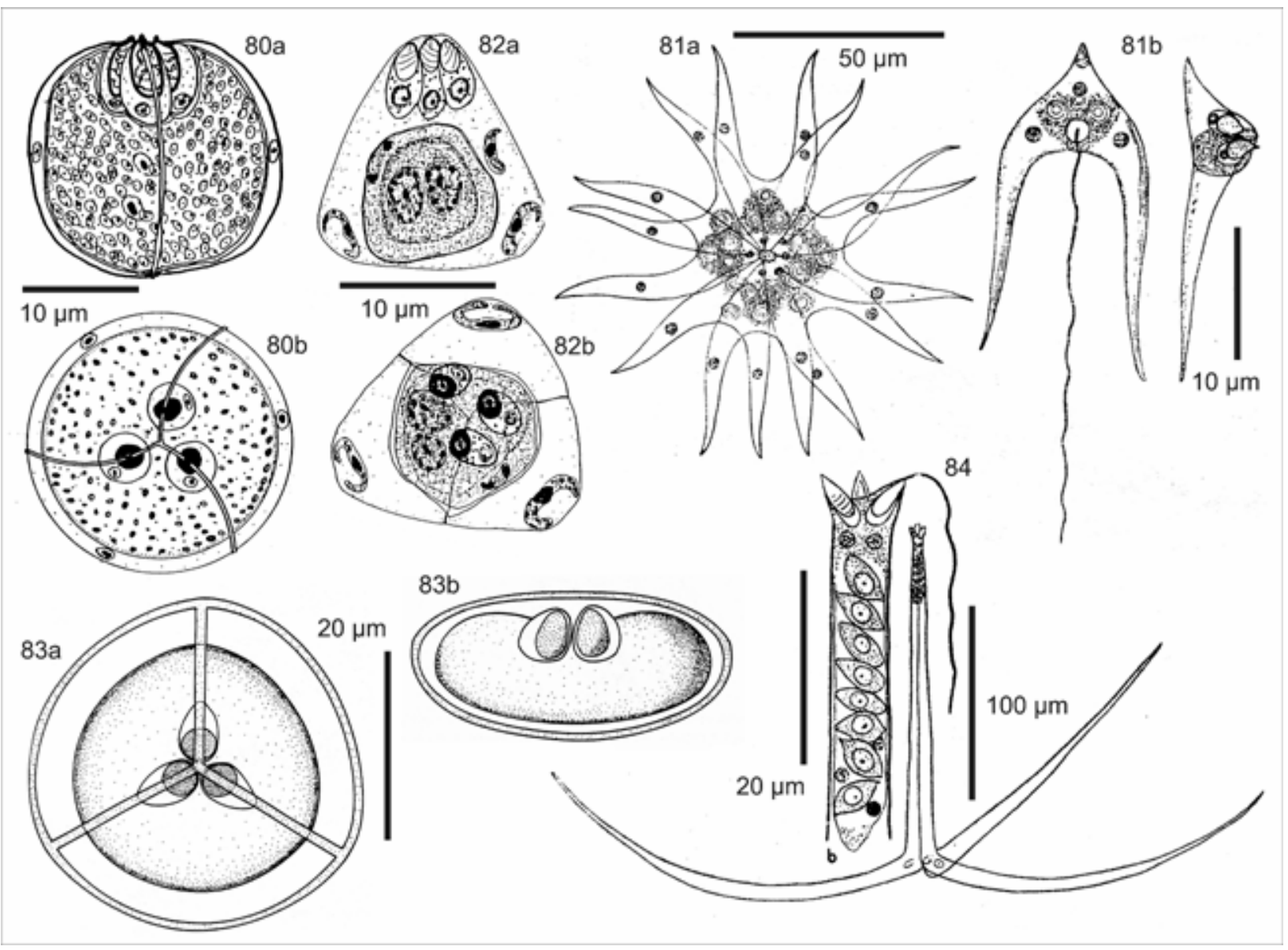

Figs. 80-84. Spores of actinosporean stages. Fig. 80. Sphaeractinomyxon (type amanieui de Puytorac, 1963); (a) side and (b) apical view. Fig. 81. Synactinomyxon (type tubificis Štolc, 1899), (a) group of eight spores from one pansporocyst, (b) single spores in apical (at left) and side view. Fig. 82. Tetractinomyxon (type intermedium Ikeda, 1912); (a) side and (b) apical view. Fig. 83. Tetraspora (type discoidea Hallett et Lester, 1999); (a) side and (b) apical view (courtesy of Dr. S.L. Hallett and Int. J. Parasitol.). Fig. 84. Triactinomyxon (type ignotum Štolc, 1899), a total view and spore body enlarged.

plasm plasmodium with many infectious cells and polar capsules located at point where the three projections converge; capsules discharge vertically to the plane of the projections. The short conical projections adhere to corresponding projections of other spores from the same pansporocyst, so that a star-like formation is formed. In freshwater oligochaetes; thus far not known as developmental stage in the life cycle of any myxosporean. Original type Synactinomyxon tubificis Štolc, 1899 described from freshwater oligochaete Tubifex tubifex in the Vltava River near Prague.

RZS: 2, DS: 6.

Tetractinomyxon Ikeda, 1912

Fig. 82

Spores rounded tetrahaedroid with polar capsules at the apex of the tetrahaeder; a single binucleate sporoplasm. In body cavity of sipunculids and in freshwater and marine polychaetes. Known as developmental stage in the life cycle of Ellipsomyxa gobii; these stages form pansporocysts divided into two halves by a central strangling and some pansporocyst contain less than eight spores. Also known as developmental stage in the life cycles of Ceratomyxa shasta and Parvicapsula minibicornis. Original type Tetractinomyxon intermedium Ikeda, 1912 described from marine sipunculid Petalostoma intermedium from off Plymouth, UK.
RZS: 2, DS: 4.

Tetraspora Hallett et Lester, 1999

Fig. 83

Spore similar to that of sphaeractinomyxon, may be anteroposteriorly flattened. Sporoplasm with over 100 infectious cells. Pansporocyst only contains four spores. In marine oligochaetes. Original type Tetraspora discoidea Hallett et Lester, 1999 described from marine oligochaete Doliodrilus diverticularis from Moreton Bay, Queensland, Australia.

RZS: 2, DS: 0

Triactinomyxon Štolc, 1899

Fig. 84

Elongated spore body with protruding tips of polar capsules and plasmodial sporoplasm with many infectious cells. Caudal projections continue as a common stem, eventually split into three slightly upwards curved, long arms attenuated as a rule into sharp tips. In freshwater and marine oligochaetes. Known as developmental stage in the life cycle of species of the genus Myxobolus and Henneguya nuesslini. Original type Triactinomyxon ignotum Štolc, 1899 described from freshwater oligochaete Tubifex sp. from the Vltava River in Prague, Czech Republic.

RZS: 11, DS: 42. 


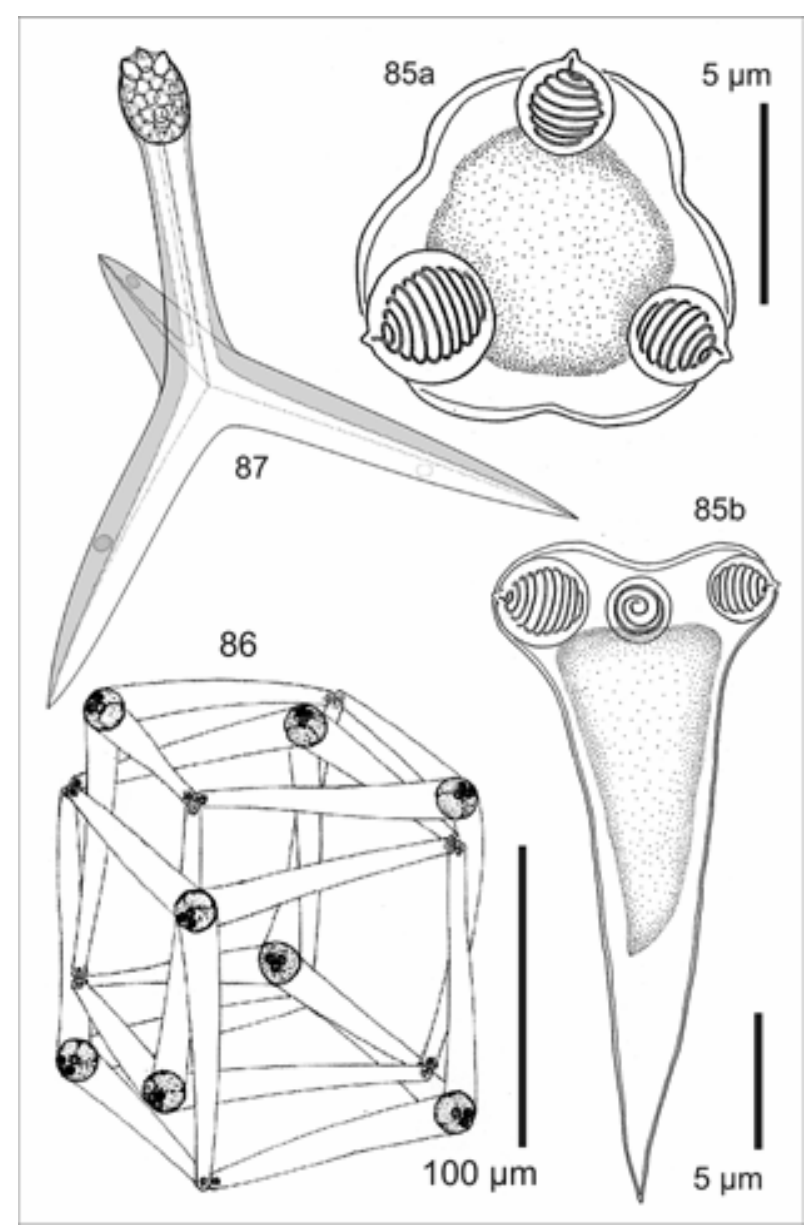

Fig. 85. Trilosporoides platessae, myxospore in apical (a) and side view (b) (courtesy of Dr. M. Køie and Folia Parasitol.). Fig. 86. Hungactinomyxon, eight spores from a pansporocyst in a cube-like formation (courtesy of Dr. K. Molnár and Syst. Parasitol.). Fig. 87. Schematic representation of the valve cells and associated sutures in Pseudotriactinomyxon (courtesy of Dr. S. Hallett and Dis. Aquat. Org.).

\section{Heliactinomyxon Bellem in Hanson et al. (2001)}

The collective group heliactinomyxon mentioned in the paper by Hanson et al. (2001) has not been published in a regular publication and its description is not accessible; the name is a nomen nudum.

\section{CONCLUSIONS}

The classification of Myxozoa is in the state of transition from the surviving mainly spore-based organisation to a new arrangement taking into account molecular characters and other criteria. It may happen that many genera established on minute differences (e.g., Alatospora vs. Pseudoalatospora or Myxobolus vs. Unicauda or Dicauda) will fuse while existing genera will be split.
To establish more appropriate classification will require several prerequisites:

It is necessary to characterise carefully the morphology of new species as well as of the existing ones. For the time being, this requirement applies only to a fraction of the 2,180 species and 60 myxosporean genera described thus far. The number of species listed above in individual genera resulted from a careful registration of all accessible literature. Nevertheless, it cannot be absolutely reliable. While compiling this paper, descriptions in marginal publications may have been missed and of course a complete revision of species and genera could not have been accomplished. However, it is quite certain that only a fraction of all existing species is known.

The existing results of phylogenetic analyses should be completed and made more reliable by adding sequences of a sufficient number of morphologically well characterised species representing most if not all described genera. It is imperative that the description of a new species should include the sequence of the SSU rRNA gene to establish properly their identity and avoid production of synonyms. An attempt to introduce an order at least in some of the Myxobolus species by using SSU rDNA analysis has been published by Cone and Easy (2005). The use of the SSU rRNA gene sequences should be exploited to a maximum while also resorting to other genes. Nevertheless, great caution has to be exerted in interpreting the results.

The impact of life-cycle characteristics has to be assessed in solving relations between species of some genera. This applies to situation of e.g., Myxobolus cultus and M. portucalensis situated side by side in the same clade yet possessing different actinospore stages (raabeia vs. triactinomyxon). This will become more topical as more life cycles become elucidated.

The role of host and tissue preferences in differentiating between closely related species has to be evaluated. The assessment of tissue tropism should be always based on species with well-corroborated site specificity.

The same applies to the value of different geographic distribution in species of certain genera (e.g., Kudoa) in finding differences between the species. With all the above factors considered it would be possible also to investigate the appearance of phenotypic variation among species and thus to expedite the progress in building an improved classification.

Acknowledgement. This study was supported by the research project of the Institute of Parasitology, Academy of Sciences of the Czech Republic (Z60220518). 


\section{REFERENCES}

ABDEL-AAL A.A., BADAWY G.A., GATTAS M.W. 2001: Light and electron microscopic studies on myxosporean parasites of some marine fishes with description of two new species. Assiut Vet. Med. J. 44: 2115-2131.

AHMED A.T.A. 1974: Kidney enlargement disease of goldfish in Japan. Jpn. J. Zool. 17: 37-65.

AKHMEROV A.K. 1954: [Speciation in myxosporidia of the genus Thelohanellus Kudo from the Amur common carp.] Dokl. Akad. Nauk SSSR 105: 1129-1132. (In Russian.)

AKHMEROV A.K. 1960: [Myxosporidia of the fishes from the Amur river basin.] Rybnoe khoz. vnutrennykh vodoemov LatSSR 5: 240-307. (In Russian.)

ALVAREZ-PELLITERO P., SITJÀ-BOBADILLA A. 1993: Pathology of Myxosporea in marine fish culture. Dis. Aquat. Org. 17: 229-236.

AMANDI A., HOLT R.A., FRYER J.L. 1985: Observations on Myxobolus insidiosus (Myxozoa: Myxosporea) a parasite of salmonid fishes. Fish Pathol. 20: 287-304.

ANDERSON C.L. 1998: Phylogenetic relationships of the Myxozoa. In: G.H. Coombs, K. Vickerman, M.A. Sleigh and A. Warren (Eds.), Evolutionary Relationships Among Protozoa. Kluwer Academic Publishers, Dordrecht/Boston/London, pp. 341-350.

ANDERSON C.L., CANNING E.U., OKAMURA B. 1998: A triploblast origin for Myxozoa? Nature 392: 346.

ANDERSON C.L., CANNING E.U., OKAMURA B. 1999a: 18S rDNA sequences indicate that PKX organism parasitizes Bryozoa. Bull. Eur. Assoc. Fish Pathol. 19: 94-97.

ANDERSON C.L., CANNING E.U., OKAMURA B. 1999b: Molecular data implicate bryozoans as hosts for PKX (Phylum Myxozoa) and identify a clade of bryozoan parasites within the Myxozoa. Parasitology 119: 555-561.

ANDREE K.B., El-MATBOULI M., HOFFMANN R.W., HEDRICK R.P. 1997: Comparison of 18 S and ITS-1 rDNA sequences of selected geographic isolates of Myxobolus cerebralis. Int. J. Parasitol. 29: 771-775.

ANDREE K.B., HEDRICK R.P., MacCONNELL E. 2002: A review of the approaches to detect Myxobolus cerebralis, the cause of salmonid whirling disease. Am. Fish. Soc. Symp. 29: $197-211$.

ANDREE K.B., SZÉKELY C., MOLNÁR K., GRESOVIAC S.J., HEDRICK R.P. 1999: Relationships among members of the genus Myxobolus (Myxozoa: Bivalvidae) based on small subunit ribosomal DNA sequences. J. Parasitol. 85: 68-74.

ARAI Y., MATSUMOTO K. 1953: On a new sporozoa, Hexacapsula neothunni $\mathrm{g}$. and $\mathrm{sp}$. $\mathrm{n}$. from the muscle of yellowfin tuna, Neothunnus macropterus. Bull. Jpn. Soc. Sci. Fish. 18: 293-298.

ASEEVA L.N. 2002: New species of myxosporeans (Myxozoa, Myxosporea) from sculpins of the northwestern Japan Sea. Acta Parasitol. 47: 179-189.

ASEEVA L.N. 2003: New species of myxosporean (Myxozoa: Myxosporea) parasites of Ceratomyxa from fishes of Peter the Great Bay (Japan Sea). J. Parasitol. 89: 1172-1180.

AUERBACH M. 1910: Die Cnidosporidien (Myxosporidien, Actinomyxidien, Microsporidien). W. Klinkhardt Verlag, Leipzig, $261 \mathrm{pp}$.

AWAKURA T., KIMURA T. 1977: On the milky condition in smoked coho salmon (Oncorhynchus kisutch) caused by myxosporidian parasite. Fish Pathol. 12: 179-184. (In Japanese.)

AZEVEDO C., CORRAL L., MATOS E. 2005: Ultrastructure of Triangulamyxa amazonica $\mathrm{n}$. gen. and n. sp. (Myxozoa, Myxosporea), a parasite of the Amazonian freshwater fish,
Sphoeroides testudineus (Teleostei, Tetrodontidae). Eur. J. Protistol. 41: 57-63.

AZEVEDO C., MATOS E. 1996: Light and electron microscopic study of a myxosporean, Tetrauronema desaequalis n. sp. (fam. Tetrauronematidae), from an Amazonian fish. J. Parasitol. 82: 288-291.

BAHRI S., ANDREE K.B., HEDRICK R.P. 2003: Morphological and phylogenetic studies of marine Myxobolus spp. from mullet in Ichkeul Lake, Tunisia. J. Eukaryot. Microbiol. 50: 463470.

BALBIANI G. 1883: Myxosporidies ou psorospermies des poissons. J. Micrograph. 7: 143-147; 197-204; 270-281.

BARTHOLOMEW J.L. 1998: Host resistance to infection by the myxosporean parasite Ceratomyxa shasta: a review. J. Aquat. Anim. Health 10: 112-120.

BARTHOLOMEW J.L., ATKINSON S.D., HALLETT S.L., ZIELINSKI C. 2005: The life cycle of Parvicapsula minibicornis, a myxozoan parasite of salmonids, involves the freshwater polychaete Manayunkia speciosa. EAFP $12^{\text {th }}$ International Conference, "Diseases of Fish and Shellfish", Copenhagen, 11-16 September 2005. Book of Abstracts, O-106, p. 110 .

BARTHOLOMEW J.L., ROHOVEC J.S., FRYER J.L. 1989: Ceratomyxa shasta, a myxosporean parasite of salmonids. Fish Disease Leaflet 80, U.S. Fish and Wildlife Service, Natl. Fish. Res. Center, Kearneysville, W. Virginia 25430.

BARTHOLOMEW J.L., WHIPPLE M.J., STEVENS D.G., FRYER J.L. 1997: The life cycle of Ceratomyxa shasta, a myxosporean parasite of salmonids, requires a freshwater polychaete as an alternate host. J. Parasitol. 83: 859-868.

BARTHOLOMEW J.L., WILSON J.C. (Eds.) 2002: Whirling Disease: Review and Current Topics. Am. Fish. Soc. Symp. 29, Bethesda, Maryland, $247 \mathrm{pp}$.

BAUER O.N. 1948: [Parasites of the Lena River]. Izv. Vsesoyuz. Nauchno-Issled. Inst. ozer. i rechn. ryb. khozyaistva 27: 157175. (In Russian.)

BAUER O.N., MUSSELIUS V.A., STRELKOV Y.A. 1981: [Diseases of pond fishes.] $2^{\text {nd }}$ edition. Legkhaya i pishchevaya promyshlenost, Moskva, 319 pp. (In Russian.)

BENAJIBA M.H., MARQUES A. 1993: The alternation of actinomyxidian and myxosporidian sporal forms in the development of Myxidium giardi (parasite of Anguilla anguilla) through oligochaetes. Bull. Eur. Assoc. Fish Pathol. 13: 100103.

BENAJIBA M.H., MARQUES A., BOUIX G. 1993: Ultrastructural data on the sporogenesis of Myxidium giardi Cépède, 1906 (Myxozoa, Myxosporidia), parasite of Anguilla anguilla (Teleostea). Eur. J. Protistol. 29: 254-261.

BERG 1898: see KUDO R.R. 1919

BOLEM A.M.G., POTE L.M. 2001: Portals of entry and systemic localisation of proliferative gill disease organisms in channel catfish Ictalurus punctatus. Dis. Aquat. Org. 48: 37-42.

BOOKER O.J., CURRENT W.L. 1981: Myxobilatus mictospora (Kudo, 1920) (Myxozoa: Myxosporea) in the largemouth bass (Micropterus salmoides Lacépède): plasmodium morphology and fine structure. J. Parasitol. 67: 859-865.

BOREHAM R.E., HENDRICK S., O'DONOGHUE P.J., STENZEL D.J. 1998: Incidental finding of Myxobolus spores (Protozoa: Myxozoa) in stool samples from patients with gastrointestinal symptoms. J. Clin. Microbiol. 36: 3728-3730.

BOWSER P.R., CONROY J.D. 1985: Histopathology of gill lesions in channel catfish associated with Henneguya. J. Wildl. Dis. 21: 177-179. 
BOYCE N.P., KABATA Z., MARGOLIS L. 1985: Investigation of the distribution, detection and biology of Henneguya salminicola (Protozoa, Myxozoa), a parasite of flesh of $\mathrm{Pa}-$ cific salmon. Can. Tech. Rep. Fish. Aquat. Sci. No. 1405, 54 pp.

BRANSON E., RIAZA A., ALVAREZ-PELLITERO P. 1991: Myxosporean infection causing intestinal disease in farmed turbot, Scophthalmus maximus (L.), (Teleostei: Scophthalmidae). J. Fish Dis. 22: 395-399.

BUCKE D., FEIST S.W., CLIFTON-HADLEY R.S. 1991: The occurrence of proliferative kidney disease (PKD) in cultured and wild fish: further observations. J. Fish Dis. 14: 583-588.

BÜTSCHLI O. 1882: Myxosporidia. In: Bronn's Klassen und Ordnungen des Tierreichs. 1. Protozoa, Second Edition. C.F. Winter, Leipzig, pp. 590-603.

CANNING E.U., CURRY A., ANDERSON C.L., OKAMURA B. 1999a: Ultrastructure of Myxidium trachinorum sp. nov. from the gallbladder of the lesser weever fish Echiichthys vipera. Parasitol. Res. 85: 910-919.

CANNING E.U., CURRY A., FEIST S.W., LONGSHAW M. OKAMURA B. 1999b: Tetracapsula bryosalmonae n. sp. for PKX organism, the cause of PKD in salmonid fish. Bull. Eur. Assoc. Fish Pathol. 19: 203-206.

CANNING E.U., CURRY A., FEIST S.W., LONGSHAW M., OKAMURA B. 2000: A new class and order of myxozoans to accommodate parasites of bryozoans with ultrastructural observations on Tetracapsula bryosalmonae (PKX organism). J. Eukaryot. Microbiol. 47: 456-468.

CANNING E.U., OKAMURA B. 2004: Biodiversity and evolution of the Myxozoa. Adv. Parasitol. 56: 44-131.

CANNING E.U., OKAMURA B., CURRY A. 1996: Development of a myxozoan parasite Tetracapsula bryozoides gen. n., sp. n. in the body cavity of Cristatella mucedo (Bryozoa Phylactolaemata). Folia Parasitol. 43: 249-261.

CANNING E.U., TOPS S., CURRY A., WOOD T.S., OKAMURA B. 2002: Ecology, development and pathogenicity of Buddenbrockia plumatellae Schröder, 1910 (Myxozoa, Malacosporea) (syn. Tetracapsula bryozoides) and establishment of Tetracapsuloides n. gen. for Tetracapsula bryosalmonae. J. Eukaryot. Microbiol. 49: 280-295.

CANNING E.U., VÁVRA J. 2000: Phylum Microsporida Balbiani, 1882. In: J.J. Lee, G.F. Leedale and P. Bradbury (Eds.), An Illustrated Guide to the Protozoa. Second Edition. Society of Protozoologists, P.O. Box 368, Lawrence, Kansas 66044, USA, pp. 39-126.

CAULLERY M., MESNIL F. 1904: Sur un type nouveau (Sphaeractinomyxon stolci n. g. n. sp.) d'Actinomyxidies et son dévelopment. C. R. Soc. Biol. (Paris) 56: 408-410.

CAVALIER-SMITH T. 1998: A revised six-kingdom system of life. Biol. Rev. 73: 203-266.

CHAKRAVARTY M. 1943: Studies on Myxosporidia from the common food fishes of Bengal. Proc. Indian Acad. Sci., Sect. B, 18: 21-35.

CHEN C.L. (Ed.) 1973: An Illustrated Guide to Fish Diseases and Causative Pathogenic Fauna and Flora in the Hubei Province. Academia Sinica Press, Beijing, 456 pp. (In Chinese.)

CHEN C.L., HSIEH S.R. 1960: Studies on sporozoa from the freshwater fishes Ophiocephalus maculatus and O. argus of China. Acta Hydrobiol. Sin. 2: 171-196.

CHEN C.L., HSIEH S.R. 1984a: New myxosporidians (Protozoa) from the freshwater fishes of China. In: Parasitic organisms of freshwater fish of China. Agricultural Publishing House, Beijing, China, pp. 13-14.

CHEN C.L., HSIEH S.R. 1984b: A new genus and two new species of family Myxobolidae from freshwater fishes of China
(Myxosporidia: Myxobolidae). Acta Zootaxon. Sin. 9: 113117.

CHEN C., MA C. 1998: Myxozoa, Myxosporea. Fauna Sinica. Ed. Committee of Fauna Sinica. Science Press, Beijing, 993 pp. (In Chinese with summaries in English.)

CHEUNG P.J., NIGRELLI R.F. 1990: Coccomyxa (Myxosporea: Bivalvulida) and Septemcapsula (Myxosporea: Multivalvulida) infections, the possible cause of death of coral catfish Plotosus anguillaris in captivity. J. Aquat. Anim. Health 2: $112-118$.

CHO J.B., KWON S.R., KIM S.K., NAM Y.K., KIM K.H. 2004: Ultrastructure and development of Ceratomyxa protopsettae Fujita, 1923 (Myxosporea) in the gall bladder of cultured olive flounder, Paralichthys olivaceus. Acta Protozool. 43: 241-250.

CONE D.K., EASY R.H. 2005: Supplemental diagnosis and molecular taxonomy of Myxobolus diaphanus (Fantham, Porter et Richardson, 1940) (Myxozoa) parasitizing Fundulus diaphanus (Cyprinodontiformes) in Nova Scotia, Canada. Folia Parasitol. 52: 217-222.

CONE D.K., MELENDY J.S. 2000: Infections of Unicauda clavicauda (Kudo, 1934) in the skin of Notropis hudsonius (Cyprinidae) from Montana, with a synopsis of the genus Unicauda Davis, 1944. Folia Parasitol. 47: 273-278.

CONE D.K., RAESLY R.L. 1995: Redescription of Myxobolus rhinichthidis (Myxosporea) parasitizing Rhinichthys cataractae, with a revised taxonomic list of species Myxobolus from North American freshwater fishes. Can. J. Fish. Aquat. Sci. 52 (Suppl. 1): 7-12.

CSABA G., KOVACS-GAYER E., BEKESI L., BUCSEK M., SZAKOLCZAI J., MOLNAR K. 1984: Studies into the possible protozoan aetiology of swimmbladder inflammation in carp fry. J. Fish Dis. 7: 39-56.

CURRENT W.L. 1979: Henneguya adiposa Minchew (Myxosporida) in the channel catfish: ultrastructure of the plasmodium wall and sporogenesis. J. Protozool. 26: 209-217.

CURRENT W.L., JANOVY J. Jr. 1978: Comparative study of ultrastructure of interlamellar and intralamellar types of Henneguya exilis Kudo from channel catfish. J. Protozool. 25: 5665.

CURRENT W.L., JANOVY J. Jr., KNIGHT S. 1979: Myxosoma funduli Kudo (Myxosporida) in Fundulus kansae: ultrastructure of the plasmodium wall and of sporogenesis. J. Protozool. 26: $574-583$

DAS M.K., HALDAR D.P. 1986: Studies on protozoan parasites from fishes: two new species of the genus Neothelohanellus n. g. (Myxosporidia). Arch. Protistenkd.132: 125-130.

DAVIS H.S. 1916: The structure and development of a myxosporidian parasite of the squeteague, Cynoscion regalis. J. Morphol. 27: 333-377.

DAVIS H.S. 1917: The Myxosporidia of the Beaufort region. A systematic and biologic study. Bull. Bur. Fish. 35: 201-243.

DAVIS H.S. 1924: A new myxosporidian parasite, the cause of the "wormy" halibut. Rep. U.S. Comm. Fish. (1923), 8 (Doc. 957): $1-5$.

DAVIS H.S. 1944: A revision of the genus Henneguya (Myxosporidia) with description of two new species. Trans. Am. Microsc. Soc. 63: 311-321.

DESPORTES I., THEODORIDES J. 1982: Données ultrastructurales sur la sporogenése de deux myxosporidies rapportés aux genres Leptotheca et Ceratomyxa parasites de Merluccius merluccius (L.) (Téléostéen Merluciidae). Protistologica 18: 533-557.

DESSER S.S., MOLNÁR K., WELLER I. 1983: Ultrastructure of sporogenesis of Thelohanellus nikolskii Akhmerov, 1955 
(Myxozoa: Myxosporea) from the common carp Cyprinus carpio. J. Parasitol. 69: 504-518.

DESSER S.S., PATERSON W.B. 1978: Ultrastructural and cytochemical observations on sporogenesis of Myxobolus sp. (Myxosporida: Myxobolidae) from the common shiner $\mathrm{No}$ tropis cornutus. J. Protozool. 25: 314-326.

DIAMANT A. 1997: Fish-to-fish transmission of a marine myxosporean. Dis. Aquat. Org. 30: 99-105.

DIAMANT A., LOM J., DYKOVÁ I. 1994: Myxidium leei n. sp., a pathogenic myxosporean of cultured sea bream Sparus aurata. Dis. Aquat. Org. 20: 137-141.

DIAMANT A., PALENZUELA O. 2005: Myxidium or Zschokkella? A systematic dilemma, illustrated by a new myxosporean from Neopomacentrus miryae (Pomacentridae) from the Northern Red Sea. EAFP $12^{\text {th }}$ International Conference, "Diseases of Fish and Shellfish", Copenhagen, 11-16 September 2005. Book of Abstracts, p. 199.

DIAMANT A., PAPERNA I. 1992: Zschokkella icterica sp. nov. (Myxozoa, Myxosporea), a pathogen of wild rabbitfish $\mathrm{Si}$ ganus luridus (Ruppell, 1829) from the Red Sea. Eur. J. Protistol. 28: 71-78.

DOFLEIN F. 1898: Studien zur Naturgeschichte der Protozoen III. Über Myxosporidien. Zool. Jahrb., Anat., 11: 281-350.

DOFLEIN F. 1899: Fortschritte auf dem Gebiete der Myxosporidienkunde. Zusammenfassende Uebersicht. Zool. Zentralbl. 6: 361-379.

DONETS S., SHULMAN S.S. 1984: Cnidosporidia. In: O.N. Bauer (Ed.), [Key to parasites of freshwater fish of the USSR.] Vol. 1. Nauka, Leningrad, USSR, pp. 88-251 (In Russian.)

DUHAMEL G.E., KENT M.L., DYBDAL N.O., HEDRICK R.P 1986: Henneguya exilis Kudo associated with granulomatous branchitis of channel catfish Ictalurus punctatus (Rafinesque). Vet. Pathol. 23: 354-361.

DUNKERLY J.S. 1915: Agarella gracilis, a new genus and species of myxosporidian, parasitic in Lepidosiren paradoxa. Proc. R. Soc. Edinburgh, Sect. A, 19: 213-219.

DYKOVÁ I., FIALA I., NIE P. 2002: Myxobolus lentisuturalis sp. n. (Myxozoa: Myxobolidae), a new muscle-infecting species from the Prussian carp, Carassius gibelio from China. Folia Parasitol. 49: 252-258.

DYKOVÁ I., LOM J. 1978: Histopathological changes in fish gills infected with myxosporidian parasite of the genus Henneguya. J. Fish Biol. 12: 197-202.

DYKOVÁ I., LOM J. 1982: Sphaerospora renicola n. sp., a myxosporean from carp kidney, and its pathogenicity. Z. Parasitenkd. 68: 259-268.

DYKOVÁ I., LOM J. 1987: Host cell hypertrophy induced by contact with trophozoites of Thelohanellus pyriformis (Myxozoa: Myxosporea). Arch. Protistenkd. 133: 285-293.

DYKOVÁ I., LOM J. 1988: Review of pathogenic myxosporeans in intensive culture of carp (Cyprinus carpio) in Europe. Folia Parasitol. 36: 289-307.

DYKOVÁ I., LOM J. 1997: Light and electron microscope observations on Sphaerospora ojiroveci n. sp. (Myxozoa) from the kidney of Pangasius sutchi (Teleostei). Eur. J. Protistol. 33: 444-451.

DYKOVÁ I., LOM J., CIRKOVIC M. 1986: Brain myxoboliasis of common carp (Cyprinus carpio) due to Myxobolus encephalicus. Bull. Eur. Assoc. Fish Pathol. 6: 10-12.

DYKOVÁ I., LOM J., KÖRTING W. 1990: Light and electron microscopic observations on the swimbladder stages of Sphaerospora renicola, a parasite of carp (Cyprinus carpio). Parasitol. Res. 76: 228-237.
EGUSA S. 1985: Myxobolus buri n. sp. (Myxosporea: Bivalvulida) parasitic in the brain of Seriola quinqueradiata Temminck et Schlegel. Fish Pathol. 19: 239-244.

EGUSA S. 1986: The order Multivalvulida Shulman, 1959 (Myxozoa: Myxosporea); a review. Fish Pathol. 21: 261-274.

EGUSA S., NAKAJIMA K. 1978: Kudoasis of cultured yellowtail. Fish Pathol. 13: 1-7.

EGUSA S., NAKAJIMA K. 1981: A new myxozoa Thelohanellus kitauei, the cause of intestinal giant cystic disease of carp. Fish Pathol. 15: 213-218.

EGUSA S., SHIOMITSU T. 1983: Two new species of the genus Kudoa (Myxosporea: Multivalvulida) from marine cultured fishes in Japan. Fish Pathol. 18: 163-171.

EIRAS J.C. 2002: Synopsis of the species of the genus Henneguya Thélohan, 1892 (Myxozoa: Myxosporea: Myxobolidae). Syst. Parasitol. 52: 43-54.

EIRAS J.C., MOLNÁR K., LU Y.S. 2005: Synopsis of the species of Myxobolus Bütschli, 1882 (Myxozoa: Myxosporea: Myxobolidae). Syst. Parasitol. 61: 1-46.

El-MANSY A., MOLNÁR K. 1997a: Extrapiscine development of Myxobolus drjagini Akhmerov, 1954 (Myxosporea: Myxobolidae) in oligochaete alternative hosts. Acta Vet. Hung. 45: 427-438.

El-MANSY A., MOLNÁR K. 1997b: Development of Myxobolus hungaricus (Myxosporea: Myxobolidae) in oligochaete alternate hosts. Dis. Aquat. Org. 31: 227-232.

El-MANSY A., MOLNÁR K., SZÉKELY C. 1998: Development of Myxobolus portucalensis Saraiva et Molnár, 1990 (Myxosporea: Myxobolidae) in the oligochaete Tubifex tubifex (Müller). Syst. Parasitol. 41: 95-103.

E1-MATBOULI M., FISCHER-SCHERL T., HOFFMANN R.W. 1992a: Transmission of Hoferellus carassii Achmerov, 1960 to goldfish Carassius auratus via an aquatic oligochaete. Bull. Eur. Assoc. Fish Pathol. 12: 54-56.

El-MATBOULI M., FISCHER-SCHERL T., HOFFMANN R.W. 1992b: Present knowledge on the life cycle, taxonomy, pathology and therapy of some Myxosporea spp. important for freshwater fish. Annu. Rev. Fish Dis. 3: 367-402.

El-MATBOULI M., HOFFMANN R.W. 1989: Experimental transmission of two Myxobolus spp. developing bisporogeny via tubificid worms. Parasitol. Res. 75: 461-464.

El-MATBOULI M., HOFFMANN R.W. 1993: Myxobolus carassii Klokaceva, 1914 also requires an oligochaete, Tubifex tubifex, as an intermediate host in its life cycle. Bull. Eur. Assoc. Fish Pathol. 13: 189-192.

El-MATBOULI M., HOFFMANN R.W. 1998: Light and electron microscopy study on the chronological development of Myxobolus cerebralis to the actinosporean stage in Tubifex tubifex. Int. J. Parasitol. 28: 195-217.

El-MATBOULI M., HOFFMANN R.W., MANDOK C. 1995: Light and electron microscopic observations on the route of the triactinomyxon-sporoplasm of Myxobolus cerebralis from epidermis into rainbow trout cartilage. J. Fish Biol. 46: 919935.

EL-MATBOULI M., HOFFMANN R.W., SCHOEL H., McDOWELL T.S., HEDRICK R.P. 1999: Whirling disease: host specificity and interaction between the actinosporean stage of Myxobolus cerebralis and rainbow trout Oncorhynchus mykiss. Dis. Aquat. Org. 35: 1-12.

ESZTERBAUER E. 2004: Genetic relationship among gillinfecting Myxobolus species (Myxosporea) of cyprinids: molecular evidence of importance of tissue specificity. Dis. Aquat. Org. 58: 35-40.

ESZTERBAUER E., KALLERT D., SZÉKELY C., MOLNÁR K. 2005: The phylogeny of the genus Henneguya (Myxosporea: Bivalvulida) on the basis of $18 \mathrm{~S}$ rDNA sequences. EAFP $12^{\text {th }}$ 
International Conference, "Diseases of Fish and Shellfish", Copenhagen, 11-16 September 2005. Book of Abstracts, O107, p. 111.

ESZTERBAUER E., SZÉKELY C. 2004: Molecular phylogeny of the kidney-parasitic Sphaerospora renicola from common carp (Cyprinus carpio) and Sphaerospora sp. from goldfish (Carassius carassius auratus). Acta Vet. Hung. 52: 469-478.

ESZTERBAUER E., SZÉKELY C., MOLNÁR K., BASKA F. 2000: Development of Myxobolus bramae (Myxosporea: Myxobolidae) in an oligochaete alternate host, Tubifex tubifex. J. Fish Dis. 23: 19-25.

EVDOKIMOVA E.B. 1973: [New species of Myxosporidia $A u$ erbachia sphaerica $\mathrm{sp} . \mathrm{n}$. and systematic position of the genus Auerbachia Meglitsch, 1968.] Parazitologiya 7: 91-92. (In Russian.)

FEIST S.W., CHILMONCZYK S., PIKE A.W. 1991: Structure and development of Sphaerospora elegans Thélohan, 1892 (Myxozoa: Myxospora) in the sticklebacks Gasterosteus aculeatus L. and Pungitius pungitius L. (Gasterosteidae). Eur. J. Protistol. 27: 269-277.

FIALA I.: Personal communication. [The phylogeny of Myxosporea (Myxozoa) based on small subunit ribosomal RNA analyses. Submitted to Int. J. Parasitol.]

FIALA I., DYKOVÁ I. 2004: The phylogeny of marine and freshwater species of the genus Chloromyxum Mingazzini, 1890 (Myxosporea: Bivalvulida) based on small subunit ribosomal RNA gene sequences. Folia Parasitol. 51: 211-214.

FISCHER-SCHERL T., El-MATBOULI M., HOFFMANN R. 1986: A new Sphaerospora sp. in brown trout (Salmo trutta m. fario) in Germany. Bull. Eur. Assoc. Fish Pathol. 6: 16-19.

FOMENA A., BOUIX G. 1997: Myxosporea (Protozoa: Myxozoa) of freshwater fishes in Africa: keys to genera and species. Syst. Parasitol. 37: 161-178.

FRIEDRICH C., INGOLIC E., FREITAG B., KASTBERGER G., HOHNMANN V., SKOFITSCH G., NEUMAISTER U., KEPKA O. 2000: A myxozoan-like parasite causing xenomas in the brain of the mole Talpa europaea L., 1758. Parasitology 121: 438-492.

FROESE R., PAULY D. (Eds.) 2005: FishBase. World Wide Web electronic publication. www.fishbase.org.,version10/2005.

FUJITA T. 1923: Studies on Myxosporidia of Japan. J. Coll. Agr. Hokkaido Imp. Univ. 10: 191-248.

GAEVSKAYA A.V., KOVALEVA A.A., SHULMAN S.S. 1982: [Neoparvicapsula gen. $\mathrm{n}$. and the position of the family Parvicapsulidae among the Myxosporidia.] Zool. Zh. 5: 774-775. (In Russian.)

GILBERT M.A., GRANATH W.O. 2003: Whirling disease of salmonid fish: life cycle, biology, and disease. J. Parasitol. 89: 658-667.

GILCHRIST J.D.F. 1924: A protozoal parasite Chloromyxum thyrsites sp. n. of the Cape-sea fish, the "snoek" (Thyrsites atun Euplin). Trans. R. Soc. S. Afr. 11: 263-273.

GOIA I., CORDEIRO N.S. 1996: Brazilian myxosporidians' check-list (Myxozoa). Acta Protozool. 35: 137-149.

GRANATA L. 1925: Gli Attinomissidi, morphologia, sviluppo, sistematica. Arch. Protistenkd. 50: 139-212.

GRASSÉ P.-P. 1960: Les myxosporidies sont des organismes pluricellulaires. C. R. Acad. Sci. Paris 251: 2638-2640.

GRASSÉ P.P. 1970: Embranchement des Myxozoaires. In: P.-P. Grassé, R.A. Poisson and O. Tuzet (Eds.), Précis de Zoologie 1, Invertébrés. Second Edition. Mason et Cie, Paris, pp. 107112.

GRASSÉ P.P., LAVETTE A. 1978: La myxosporidie Sphaeromyxa sabrazesi et le nouvel embranchement de Myxozoaires (Myxozoa). Recherches sur 1'état pluricellulaire primitif et considerations phylogénetiques. Ann. Sci. Nat., Zool. (Paris), 2: 193-285.

GROSSEL G.W., DYKOVÁ I., HANDLINGER J., MUNDAY B.L. 2003: Pentacapsula neurophila sp.n. (Multivalvulida) from the central nervous system of striped trumpeter, Latris lineata (Forster). J. Fish Dis. 26: 315-320.

GROSSHEIDER G., KÖRTING W. 1992: First evidence that Hoferellus cyprini (Doflein, 1898) is transmitted by Nais sp. Bull. Eur. Assoc. Fish Pathol. 12: 17-20.

GROSSHEIDER G., KÖRTING W. 1993: Experimental transmission of Sphaerospora renicola to common carp Cyprinus carpio fry. Dis. Aquat. Org. 16: 91-95.

GRUPCHEVA G., DYKOVÁ I., LOM J. 1985: Seasonal fluctuation in the prevalence of Sphaerospora renicola and myxosporean bloodstream stages in carp fingerlings in Bulgaria. Folia Parasitol. 32: 193-203.

GUPTA S., KHERA S. 1988: On a new myxozoan parasite (Myxozoa) Lomosporus indicus gen. et sp. $\mathrm{n}$. from the freshwater fish, Labeo calbasu (Hamilton). Acta Protozool. 27: 171-175.

GURLEY R.R. 1893: On the classification of the Myxosporidia, a group of protozoan parasites infesting fishes. Bull. U.S. Fish. Comm. 11: 407-420.

GURLEY R.R. 1894: The Myxosporidia, or psorosperms of fishes, and the epidemic produced by them. Rep. U.S. Fish. Comm. 26: 65-304.

HAHN C.W. 1917: On the sporozoan parasites of the fishes of Woods Hole and vicinity III. On the Chloromyxum clupeidae of Clupea harengus (Young) and P. aestivalis (Young). J. Parasitol. 4: 13-20.

HALLETT S.L., ATKINSON S.D., El-MATBOULI M. 2002: Molecular characterisation of two aurantiactinomyxon (Myxozoa) phenotypes reveals one genotype. J. Fish Dis. 25: 627-631.

HALLETT S.L., ATKINSON S.D., ERSÉUS C., El-MATBOULI M. 2004: Molecular methods clarify morphometric variation in triactinomyxon spores (Myxozoa) released from different oligochaete hosts. Syst. Parasitol. 57: 1-14.

HALLETT S.L., ATKINSON S.D., HOLT R.A., BANNER C.R., BARTHOLOMEW J.L. 2006: First record of Chloromyxum, Chloromyxum auratum n. sp. (Myxozoa), in feral goldfish (Carassius auratus). J. Parasitol. (In press.)

HALLETT S.L., ATKINSON S.D., SCHÖL H., El-MATBOULI M. 2003: Characterisation of two novel types of hexactinomyxon spores (Myxozoa) with subsidiary protrusion on their caudal processes. Dis. Aquat. Org. 55: 45-57.

HALLETT S.L., ERSÉUS C., LESTER G.J.K. 1999: Actinosporeans (Myxozoa) from marine oligochaetes from the Great Barrier Reef. Syst. Parasitol. 44: 49-57.

HALLETT S.L., LESTER R.J.G. 1999: Actinosporeans (Myxozoa) with four developing spores within a pansporocyst: Tetraspora discoidea $\mathrm{n}$. g. n. sp. and Tetraspora rotundum n. sp. Int. J. Parasitol. 29: 419-427.

HANSON L.A., LIN D.J., POTEL M.W., SHIVAJI R. 2001: Small subunit rRNA gene comparisons of four actinosporean species to establish a polymerase chain reaction test for the causative agent of proliferative gill disease in channel catfish. J. Aquat. Anim. Health 13: 117-123.

HARTMANN M. 1923-1925: Sporozoa. In: W. Kükenthal and T. Krumbach (Eds.), Handbuch der Zoologie. Vol. 1. Berlin and Leipzig, pp. 186-192.

HAUSMANN K., HÜLSMANN N., RADEK R. 2003: Protistology. E. Schweizerbart'sche Verlagsbuchhandlung, Berlin-Stuttgart, $379 \mathrm{pp}$.

HEDRICK R.P., BAXA D.V., DeKINKELIN P., OKAMURA B. 2004: Malacosporean-like spores in urine of rainbow trout re- 
act with antibody and DNA probes to Tetracapsuloides bryosalmonae. Parasitol. Res. 92: 81-88.

HEDRICK R.P., El-MATBOULI M. 2002: Recent advances in taxonomy, life cycle, and development of Myxobolus cerebralis in the fish and oligochaete hosts. Am. Fish. Soc. Symp. 29: 45-53.

HEDRICK R.P., El-MATBOULI M., ADKINSON M.A., MacCONELL E. 1998: Whirling disease: re-emergence among wild trout. Immunol. Rev. 166: 365-376.

HEDRICK R.P., MacCONNELL E., DeKINKELIN P. 1993: Proliferative kidney disease of salmonid fish. Annu. Rev. Fish Dis. 3: $277-290$.

HEDRICK R.P., McDOWELL T., GROFF J.M. 1990: Sphaerospora ictaluri n. sp. (Myxosporea: Sphaerosporidae) observed in the kidney of channel catfish, Ictalurus punctatus Rafinesque. J. Protozool. 37: 107-112.

HENDERSON M., OKAMURA B. 2004: The phylogeography of salmonid proliferative kidney disease in Europe and North America. Proc. R. Soc. London, B, 271: 1729-1736.

HERMANS W., KÖRTING W. 1985: Sphaerospora tincae Plehn, 1925 in tench, Tinca tinca L., fry. J. Fish Dis. 8: 281-288.

HERVIO D.M.L., KENT M.L., KHATTRA J., SAKANARI J., YOKOYAMA H., DEVLIN R.H. 1997: Taxonomy of Kudoa species (Myxosporea), using a small-subunit ribosomal DNA sequence. Can. J. Zool. 75: 2112-2119.

HESSEN E.M., ZAMZAME M.L. 2004: Myxobolus sp.: a possible new opportunistic parasite in immunocompromised patients in Ismailia. J. Egypt. Soc. Parasitol. 34: 925-930.

HIGGINS M.J., MARGOLIS L., KENT M.L. 1993: Arrested development in a freshwater myxosporean, Myxidium salvelini, following transfer of its host, the sockeye salmon (Oncorhynchus nerka), to sea water. J. Parasitol. 79: 403-407.

HINE P.M. 1980: A review of some species of Myxidium Bütschli, 1882 (Myxosporea) from eels (Anguilla spp.). J. Protozool. 27: 260-267.

HOFER B. 1903: Ueber die Drehkrankheit der Regenbogenforelle. Allgem. Fischerei-Ztg. 18: 7-8.

HOFER B. 1904: Handbuch der Fischkrankheiten. Schweizerbart'sche Verlagsbuchhandlung, Stuttgart, $359 \mathrm{pp}$.

HOFFMAN G.L. 1990: Myxobolus cerebralis, a worldwide cause of salmonid whirling disease. J. Aquat. Anim. Health 2: 30 37.

HOFFMAN G.L. 1999: Parasites of North American Freshwater Fishes. Second edition. Comstock Publishing Associates, Cornell University Press, Ithaca, 539 pp.

HOFFMAN G.L., WALKER R. 1978: A new myxosporidian, Dicauda atherinoidi n. g., n. sp., of the minnow, Notropis atherinoides Rafinesque. J. Fish Dis. 1: 343-349.

HOFFMANN R. 2005: Fischkrankheiten. Eugen Ulmer Verlag, Stuttgart, $224 \mathrm{pp}$.

HOLZER A.S., SOMMERVILLE C., WOOTTEN R. 2003: Tracing the route of Sphaerospora truttae from the entry locus to the target organ of the host, Salmo salar L., using an optimized and specific in situ hybridization technique. J. Fish Dis. 26: 647-655.

HOLZER A.S., SOMMERVILLE C., WOOTTEN R. 2004: Molecular relationships and phylogeny in a community of myxosporeans and actinosporeans based on their $18 \mathrm{~S}$ rDNA sequences. Int. J. Parasitol. 34: 1099-1111.

HOSHINA T. 1952: Notes on some myxosporidian parasites of fishes in Japan. J. Tokyo Univ. Fish. 39: 69-89.

HOSHINA T., HOSHODA S. 1957: On a new myxosporidian parasite Thelohanellus cyprini $\mathrm{n}$. sp. parasitic in the fin of $\mathrm{Cy}$ prinus carpio. J. Tokyo Univ. Fish. 43: 71-73.

HSIEH S.R., CHEN C.L. 1984a: Septemcapsula yasunagai gen. et sp. nov., representative of a new family of the class Myxo- sporea. Acta Zootaxon. Sin. 9: 225-227. (In Chinese with English summary.)

HSIEH S.R., CHEN C.L. 1984b: A new species of myxosporidian parasite (Ceratomyxa hongzensis) from freshwater fishes of China. Acta Zootaxon. Sin. 9: 337-338. (In Chinese with English summary.)

HSIEH S.R., XIAO C. 1993: Discovery of a myxosporidean with four valves in a freshwater fish and discussion of its taxonomic position. Asian Fish. Sci. 6: 239-243.

IKEDA J. 1912: Studies on some sporozoan parasites of sipunculoids. I. The life history of a new Actinomyxidian, Tetractinomyxon intermedium g. et sp. nov. Arch. Protistenkd. 25: 240242.

JAMESON A.P. 1929: Myxosporidia from Californian fishes. J. Parasitol. 16: 59-68.

JANISZEWSKA J. 1952: Siedleckiella silesica n. g. n. sp. Actinomyxidia (Cnidosporidia). Zool. Pol.. 6: 49-56.

JANISZEWSKA J. 1955: Actinomyxidia: morphology, ecology, history of investigations, systematics, development. Acta Parasitol. Pol. 2: 405-453.

JANISZEWSKA J. 1957: Actinomyxidia II. New systematics, sexual cycle, description of new genera and species. Zool. Pol. 8: 3-34.

JAYASRI M., HOFFMAN G.L. 1982: Review of Myxidium (Protozoa: Myxozoa: Myxosporea). Protozool. Abstr. 6: 61-91.

JONES S.R.M., PROSPERI-PORTA G., DAWE S.C., BARNES D.P. 2003: Distribution, prevalence and severity of Parvicapsula minibicornis infections among anadromous salmonids in the Fraser River, British Columbia, Canada. Dis. Aquat. Org. 54: 49-54.

JURINE L.L. 1825: Histoire des poissons du Lac Léman. Mém. Soc. Phys. Hist. Nat., Genève, 3

KABATA Z., WHITAKER D.J. 1981: Two species of Kudoa (Myxosporea; Multivalvulida) parasitic in the flesh of Merluccius productus (Ayres, 1855) (Pisces: Teleostei) in the Canadian Pacific. Can. J. Zool. 59: 2058-2091.

KALAVATI C., LONGSHAW M., MacKENZIE K. 1996: Two species of myxozoan parasites (Myxosporea: Bivalvulida), including a new genus, from Patagonotothen sima (Richardson, 1845) (Pisces: Teleostei) in the southwest Atlantic. Syst. Parasitol. 34: 67-70.

KALAVATI C., NARASIMHAMURTI C.C. 1984: A new myxosporidian, Rudicapsula esomi $\mathrm{n}$. gen. n. sp., from the freshwater fish, Esomus sp. Z. Parasitenkd. 70: 21-27.

KALAVATI C., NARASIMHAMURTI C.C. 1987: A new myxosporidian, Parazschokkella melanosticti gen. n., sp. n. prasitic in the gall bladder of the toad, Bufo melanostictus. Acta Protozool. 26: 189-194.

KALLERT D.M., ESZTERBAUER E., El-MATBOULI M., ERSÉUS C., HAAS W. 2005a: The life cycle of Henneguya nuesslini Schuberg et Schröder, 1905 (Myxozoa) involves a triactinomyxon-type actinospore. J. Fish Dis. 28: 71-79.

KALLERT D.M., ESZTERBAUER E., ERSÉUS C., ElMATBOULI M., HAAS W. 2005b: Life cycle studies of Myxobolus parviformis sp. n. (Myxozoa: Myxobolidae) from bream. Dis. Aquat. Org. 66: 233-243.

KARLSBAKK E., SAETHER P.A., HOSTLUND C., FJELLSOY K.R., NYLUND A. 2002: Parvicapsula pseudobranchicola n. sp. (Myxozoa), a microsporidian infecting the pseudobranch of cultured Atlantic salmon (Salmo salar) in Norway. Bull. Eur. Assoc. Fish Pathol. 22: 381-387.

KELLEY G.O., BEAUCHAMP K.A., HEDRICK R.P. 2004: Phylogenetic comparison of the Myxosporea based on an actin cDNA isolated from Myxobolus cerebralis. J. Eukaryot. Microbiol. 51: 660-663. 
KENT M.L., ANDREE K.B., BARTHOLOMEW J.B., ElMATBOULI M., DESSER S.S., DEVLIN R.H., FEIST S.W., HEDRICK R.P., HOFFMAN R.W., KHATTRA J., HALLETT S.L., LESTER J.G., LONGSHAW M., PALENZUELA O., SIDDALL M.E., XIAO C. 2001: Recent advances in our knowledge of the Myxozoa. J. Eukaryot. Microbiol. 48: 395 413.

KENT M.L., KHATTRA J., HEDRICK R.P., DEVLIN R.H. 2000a: Tetracapsula renicola n. sp. (Myxozoa: Saccosporidae); the PKX myxozoan - the cause of proliferative kidney disease of salmonid fishes. J. Parasitol. 86: 103-111.

KENT M.L., LOM J. 1999: Can a species of Myxozoa be described based solely on their actinosporean stage? Parasitol. Today 15: 472-473.

KENT M.L., MARGOLIS M., CORLISS J.O. 1994a: The demise of a class of protists: taxonomical and nomenclatural revisions proposed for the phylum Myxozoa Grassé, 1970. Can. J. Zool. 72: 932-937.

KENT M.L., MARGOLIS M., WHITAKER D.J., HOSKINS G.E., McDONALD T.E. 1994b: Review of Myxosporea of importance in salmonid fisheries and aquaculture in British Columbia. Folia Parasitol. 41: 27-37.

KENT M.L., MOSER M. 1990: Ortholinea alata n. sp. (Myxosporea: Ortholineidae) in the northern butterfly fish Chaetodon rainfordi. J. Protozool. 37: 49-51.

KENT M.L., MOSER M., MARQUES A., LOM J. 2000b: Phylum Myxozoa Grassé, 1970. In: J.J. Lee, G.F. Leedale and P. Bradbury (Eds.), The Illustrated Guide to the Protozoa. Second Edition. Vol. 1. Society of Protozoologists, Lawrence, Kansas, pp. 127-148.

KENT M.L., WHITAKER D.J., DAWE S.C. 1997: Parvicapsula minibicornis n. sp. (Myxozoa, Myxosporea) from the kidney of sockeye salmon (Oncorhynchus nerka) from British Columbia, Canada. J. Parasitol. 83: 1153-1156.

KENT M.L., WHITAKER D.J., MARGOLIS L. 1993: Transmission of Myxobolus arcticus Pugachev and Khokhlov, 1979, via a triactinomyxon from the aquatic oligochaete Stylodrilus heringianus (Lumbriculidae). Can. J. Zool. 71: 1207-1211.

KØIE M. 2003a: Ellipsomyxa gobii gen. et sp. n. (Myxozoa: Ceratomyxidae) in the common goby Pomatoschistus microps (Teleostei: Gobiidae) from Denmark. Folia Parasitol. 50: 269-271.

KØIE M. 2003b: Parvicapsula spinachiae n. sp. (Myxozoa, Parvicapsulidae) in Spinachia spinachia (L.) (Teleostei, Gasterosteidae) from Denmark. Parasitol. Res. 90: 445-448.

KØIE M. 2005a: The Spionidae (Polychaeta) act as invertebrate hosts for marine Myxozoa. Bull. Eur. Assoc. Fish Pathol. 25: $179-181$.

KØIE M. 2005b: Trilosporoides platessae gen. et sp. n. (Myxozoa: Multivalvulida) in the plaice Pleuronectes platessae (Teleostei: Pleuronectidae) from Denmark. Folia Parasitol. 52: 304-306.

KØIE M., WHIPPS C.M., KENT M.L. 2004: Ellipsomyxa gobii (Myxozoa: Ceratomyxidae) in the common goby Pomatoschistus microps (Annelida: Polychaeta) uses Nereis spp. (Annelida: Polychaeta) as invertebrate hosts. Folia Parasitol. 51: 14-18.

KÖRTING W., HOFFMANN R., NEUKIRCH M., FUHRMANN H. 1984: Myxosporidienbedingte Schwimmblasenentzündung bei Karpfenbrut. Berl. Münch. Tierärztl. Wochenschr. 97: 99104

KOVALEVA A.A. 1988: Suborder Sphaeromyxina (Myxosporea, Bivalvulida), its structure and placement in myxosporean system. Zool. Zh. 67: 1616-1620. (In Russian with English summary.)
KOVALEVA A.A. 1989: New genus of myxosporidian family Myxoproteidae (Cnidospora, Myxosporea) from the NorthWestern Atlantic. Zool. Zh. 68: 130-132. (In Russian with English summary.)

KOVALEVA A.A., GAEVSKAYA A.V. 1983: [First data on fish myxosporidia of the south-eastern Pacific open waters.] Vest. Zool. 17: 6-11. (In Russian.)

KOVALEVA A.A., GAEVSKAYA A.V., KRASIN V.K. 1986 New species of myxosporidians (Protozoa, Myxosporidia) from macrourid fishes in the Northern Pacific. Zool. Zh. 65: 1571-1573. (In Russian with English summary.)

KOVALEVA A.A., SHULMAN S.S. 1978: Multivalvulea of fishes. In: M.V. Krylov (Ed.), Fauna and Systematics of Unicellular Animals. Tr. Zool. Inst. Akad. Nauk SSSR 78: 16-29. (In Russian with English summary.)

KOVALEVA A.A., SHULMAN S.S., YAKOVLEV V.N. 1979 Myxosporidia of the genus Kudoa (Myxosporidia, Multivalvulea) from the Atlantic Ocean. In: M.V. Krylov (Ed.), Systematics and Ecology of Sporozoans and Cnidosporidia. Akademia Nauk SSSR, Leningrad, 42-64. (In Russian with English summary.)

KOVALEVA A.A., ZUBCHENKO A.V., KRASIN V.K. 1983 Establishment of a new myxosporidean family (Protozoa, Myxosporidia) with a description of two new genera. Parazitologiya 17: 1295-1202. (In Russian with English summary.)

KUDO R.R. 1919: Studies on Myxosporidia. A synopsis on genera and species of Myxosporidia. Ill. Biol. Monogr. 5: 1-265.

KUDO R.R. 1929: Histozoic Myxosporidia found in freshwater fishes of Illinois. Arch. Protistenkd. 65: 364-378.

KUDO R.R. 1933: A taxonomic consideration of Myxosporidia. Trans. Am. Microsc. Soc. 52: 195-216.

KUDO R.R. 1934: Studies on some protozoan parasites of fishes of Illinois. Ill. Biol. Monogr. 13: 1-41.

KUNDU T.K., HALDAR D.P. 1981: Studies in Thelohanellus jiroveci $\mathrm{sp}$. $\mathrm{n}$., a new myxosporidian parasitic in a common teleost fish. Acta Soc. Zool. Bohemoslov. 45: 94-101.

KUZNETSOVA I.G. 1977: Myxosporidians of Chondrostei from the Patagonian shelf. Parazitologiya 11: 74-77. (In Russian with English summary.)

LAIRD M. 1953: The Protozoa of New Zealand intertidal zone fishes. Trans. R. Soc. N. Z. 81: 79-143.

LANDSBERG J.H., LOM J. 1991: Taxonomy of the genus Myxobolus (Myxobolidae, Myxosporea): current listing of species and revision of synonyms. Syst. Parasitol. 18: 165168.

LARSSON J.I.R. 2005: Molecular versus morphological approach to microsporidian classification. Folia Parasitol. 52: 143-144.

LÉGER L. 1906: Myxosporidies nouvelles parasites des poissons. I. Sur une nouvelle maladie myxosporidienne de la truite indigène. II. Sur une nouvelle Myxosporidie de la tanche commune. Ann. Univ. Grenoble 18: 267-272.

LÉGER L. 1931: Myxosporidies nouvelles ou peu connues du genre "Myxidium" chez les poissons d'eau douce. Trav. Lab. Hydrobiol. Piscicult. Univ. Grenoble 1931: 231-242.

LÉGER L., HESSE E. 1907: Sur une nouvelle Myxosporidie parasite de la sardine. C. R. Acad. Sci. Paris 145: 85-87.

LESTER R.J.G. 1982: Unicapsula seriolae n. sp. (Myxosporea, Multivalvulida) from Australian yellowtail kingfish Seriola lalandi. J. Protozool. 29: 584-587.

LIN D., HANSON L.A., POTE L.M. 1999: Small subunit ribosomal RNA sequence of Henneguya exilis (Class Myxosporea) identifies the actinosporean stage from an oligochaete host. J. Eukaryot. Microbiol. 46: 66-68.

LISTERBARGER J.K., MITCHELL L.G. 1980: Scanning electron microscopy of spores of the myxosporidians Chloro- 
myxum trijugum Kudo and Chloromyxum catostomi Kudo. J. Protozool. 27: 155-159.

LIYANAGE Y., YOKOYAMA H., WAKABAYASHI H. 2003: Evaluation of a vector-control strategy of haemorrhagic thelohanellosis in carp, caused by Thelohanellus hovorkai (Myxozoa). Dis. Aquat. Org. 55: 31-35.

LOM J. 1969: Notes on the ultrastructure and sporoblast development in fish parasitizing myxosporidian of the genus Sphaeromyxa. Z. Zellforsch. 97: 416-437.

LOM J. 1985: Diseases caused by protistans. In: O. Kinne (Ed.), Diseases of Marine Animals. Vol. 4, Part I. Biologische Anstalt Helgoland, Hamburg, pp. 114-168.

LOM J. 1986: Hoferellus cyprini (Doflein, 1898) Berg, 1898 (syn. Mitraspora cyprini Fujita, 1912), Myxobilatus nostalgicus sp. n. and related species: partial revision of two myxosporean genera. Folia Parasitol. 33: 289-296.

LOM J. 1990: Phylum Myxozoa. In: L. Margulis, J.O. Corliss, M. Melkonian and D.J. Chapman (Eds.), Handbook of Protoctista. Jones and Bartlett, Boston, pp. 36-52.

LOM J. 2002: A catalogue of described genera and species of microsporidians parasitic in fish. Syst. Parasitol. 53: 81-99.

LOM J. 2004: Morphology and ultrastructure of Sphaeromyxa noblei sp. n. (Myxozoa), parasite of Heteroclinus whiteleggii (Pisces) from Australian New South Wales coast. Folia Parasitol. 51: 19-26.

LOM J., ARTHUR J.R. 1989: A guideline for the preparation of species descriptions in Myxosporea. J. Fish Dis. 12: 151-156.

LOM J., DYKOVÁ I. 1984: Pathogenicity of some protozoan parasites of cyprinid fishes. Symp. Biol. Hung. 23: 99-118.

LOM J., DYKOVÁ I. 1988: Sporogenesis and spore structure in Kudoa lunata (Myxosporea, Multivalvulida). Parasitol. Res. 74: 521-530.

LOM J., DYKOVÁ I. 1992: Protozoan Parasites of Fishes. Elsevier, New York, $315 \mathrm{pp}$.

LOM J., DYKOVÁ I. 1993: Scanning electron microscopic revision of common species of the genus Chloromyxum (Мyxozoa: Myxosporea) infecting European freshwater fishes. Folia Parasitol. 40: 161-174.

LOM J., DYKOVÁ I. 1994: Studies on protozoan parasites of Australian fishes. III. Species of the genus Myxobolus Bütschli, 1882. Eur. J. Protistol. 30: 431-439.

LOM J., DYKOVÁ I. 1995a: Myxosporea (Phylum Myxozoa). In: P.T.K. Woo (Ed.), Fish Diseases and Disorders. Vol. 1. CAB International, Wallingford, pp. 97-148.

LOM J., DYKOVÁ I. 1995b: New species of the genera Zschokkella and Ortholinea (Myxozoa) from the Southeast Asian teleost fish, Tetraodon fluviatilis. Folia Parasitol. 42: 161168.

LOM J., DYKOVÁ I. 1997: Ultrastructural features of the actinosporean phase of Myxosporea (phylum Myxozoa): a comparative study. Acta Protozool. 36: 83-103.

LOM J., DYKOVÁ I., FEIST S.W. 1989: Myxosporea-induced xenoma formation in pike (Esox lucius) renal corpuscles associated with Myxidium lieberkuehni infection. Eur. J. Protistol. 24: $271-280$

LOM J., DYKOVÁ I., PAVLÁSKOVÁ M. 1983a: "Unidentified" mobile protozoans from the blood of carp and some unsolved problems of myxosporean life cycles. J. Protozool. 30: $497-$ 508.

LOM J., DYKOVÁ I., PAVLÁSKOVÁ M., GRUPCHEVA G. 1983b: Sphaerospora molnari sp. nov. (Myxozoa: Myxosporea), an agent of gill, skin and blood sphaerosporosis of common carp in Europe. Parasitology 36: 529-535.

LOM J., McGEORGE J., FEIST S.W., MORRIS D., ADAMS A. 1997a: Guidelines for the uniform characterisation of the acti- nosporean stages of the phylum Myxozoa. Dis. Aquat. Org. 30: 1-9.

LOM J., MOLNÁR K., DYKOVÁ I. 1986: Hoferellus gilsoni (Debaissiueux, 1925) comb. n. (Myxozoa, Myxosporea): redescription and mode of attachment to the epithelium of the urinary bladder of its host, the European eel. Protistologica 22: 405-413.

LOM J., NOBLE E.R. 1984: Revised classification of the Myxosporea Bütschli, 1881. Folia Parasitol. 31: 193-205.

LOM J., NOBLE E.R., LAIRD M. 1975: Myxosporidia from the deep-sea fish Macrourus berglax, off Newfoundland and Iceland. Folia Parasitol. 22: 105-109.

LOM J., PIKE A.W., DYKOVÁ I. 1991a: Myxobolus sandrae Reuss, 1906, the agent of vertebral column deformities of perch Perca fluviatilis in northeast Scotland. Dis. Aquat. Org. 12: 49-53.

LOM J., de PUYTORAC P. 1965a: Observations sur l'ultrastructure des trophozoites des myxosporidies. C. R. Acad. Sci. Paris 260: 2588-2590.

LOM J., de PUYTORAC P. 1965b: Studies on the myxosporidian ultrastructure and polar capsule development. Protistologica 1: $53-65$.

LOM J., TONGUTHAI K., DYKOVÁ I. 1991b: Hennegoides longitudinalis $\mathrm{n}$. gen. n. sp., a myxosporean parasite of Osphronemus gourami from Thailand. Dis. Aquat. Org. 11: 143-145.

LOM J., YOKOYAMA H., DYKOVÁ I. 1997b: Comparative ultrastructure of Aurantiactinomyxon and Raabeia, actinosporean stages of myxozoan life cycles. Arch. Protistenkd. 148: $173-189$.

LONGSHAW M., Le DEUFF R.M., HARRIS A.F., FEIST S.W. 2002: Development of proliferative kidney disease in rainbow trout, Oncorhynchus mykiss (Walbaum), following short-term exposure to Tetracapsula bryosalmonae infected bryozoans. J. Fish Dis. 25: 443-449.

LONGSHAW M., FEIST S.W. 2005: The role of morphology and ecology in the transmission of actinospore types (Myxozoa) in freshwater ecosystems. EAFP $12^{\text {th }}$ International Conference, "Diseases of Fish and Shellfish", Copenhagen, 11-16 September 2005. Book of Abstracts, P.13.10, p. 195.

LONGSHAW M., FREAR P.A., FEIST S.W. 2003: Myxobolus buckei sp. n. (Myxozoa), a new pathogenic parasite from the spinal column of three cyprinid fishes from the United Kingdom. Folia Parasitol. 50: 251-262.

LONGSHAW M., FREAR P.A., FEIST S.W. 2005: Descriptions, development and pathogenicity of myxozoan (Myxozoa: Myxosporea) parasites of juvenile cyprinids (Pisces: Cyprinidaae). J. Fish Dis. 8: 489-508.

LOWENSTINE L.J., RIDEOUT B.A., GARDNER M., BUSCH M., MACE M., BARTHOLOMEW J., GARDINER C.H. 2002: Myxozoanosis in waterfowl: a new host record? Proc. Am. Soc. Zoo Veterinarians 2002: 86-87.

MA C.L., DONG X.M., WANG C.S. 1982: Report on new species of fish parasites in the region of Sichuan. Acta Zootax. Sin. 7: 341-432. (In Chinese with English summary.)

MARGOLIS L., EVELIN T.P.T. 1975: Ceratomyxa shasta (Myxosporida) disease in chum salmon (Oncorhynchus keta) in British Columbia. J. Fish. Res. Board Can. 32: 1640-1643.

MARQUES A. 1984: Contribution à la connaissance des Actinomyxidies: Ultrastructure, cycle biologique, systématique. Thesis, Université des Sciences et Techniques du Languedoc, Montpellier, $218 \mathrm{pp}$.

MARQUES A. 1986-1987: La sexualité chez les actinomyxidies: étude chez Neoactinomyxon eiseniellae (Ormières et Frézil, 1969), Actinosporea, Noble, 1980; Myxozoa Grassé, 1970. Ann. Sci. Nat., Zool., Paris, $13^{\mathrm{e}}$ sér, 8: 81-101. 
MATSUMOTO K., ARAI Y. 1954: On a new Myxosporidia, Chloromyxum musculoliquefaciens sp. $\mathrm{n}$. and Neochloromyxum cruciformum g. n., sp. n., from the jellied muscle of swordfish Xiphias gladius L., and common Japanese sea bass Lateolabrax japonicus (Temminck et Schlegel). Bull. Jpn. Soc. Sci. Fish. 20: 469-477.

McGEORGE J., SOMMERVILLE C., WOOTTEN R. 1994: Light and electron microscope observations on extrasporogonic and sporogonic stages of a myxosporean parasite of the genus Sphaerospora Thélohan, 1892 from Atlantic salmon, Salmo salar L., in Scotland. J. Fish Dis. 17: 227-238.

McGEORGE J., SOMMERVILLE C., WOOTTEN R. 1996a: Epizootiology of Sphaerospora truttae (Myxozoa: Myxosporea) infections of Atlantic salmon Salmo salar at freshwater smolt producing hatcheries in Scotland. Dis. Aquat. Org. 26: 33-41.

McGEORGE J., SOMMERVILLE C., WOOTTEN R. 1996b: Transmission experiments to determine the relationship between Sphaerospora sp. from Atlantic salmon, Salmo salar, and Sphaerospora truttae: a revised species description for $S$. truttae. Folia Parasitol. 43: 107-116.

McGURK C., MORRIS D.J., BRON J.E., ADAMS A. 2005: The morphology of Tetracapsuloides bryosalmonae (Myxozoa: Malacosporea) spores released from Fredericella sultana (Bryozoa: Phylactolaemata). J. Fish Dis. 28: 307-312.

MEGLITSCH P.A. 1947: Studies on Myxosporidia from the Beaufort region II. Observations on Kudoa clupeidae (Hahn) g. n. J. Parasitol. 33: 271-277.

MEGLITSCH P.A. 1960: Some coelozoic myxosporidia from New Zealand fishes. I. General and family Ceratomyxidae. J. Parasitol. 33: 265-365.

MEGLITSCH P.A. 1968: Some coelozoic myxosporidia from New Zealand fishes. II. On a new genus of Myxosporida, $A u$ erbachia. Proc. Iowa Acad. Sci. 75: 397-401.

MEGLITSCH P.A. 1970: Some coelozoic Myxosporida from New Zealand fishes: family Sphaerosporidae. J. Protozool. 17: 112-115.

MERCIER L. 1908: Notes sur les Myxosporidies. Arch. Zool. Exp. Gén. 8: 53-62.

MINCHEW C.D. 1977: Five new species of Henneguya (Protozoa: Myxosporida) from ictalurid fishes. J. Protozool. 24: 213-220.

MINGAZZINI P. 1890: Sullo sviluppo dei Myxosporidi. Boll. Soc. Nat. Napoli 4: 160-164.

MITCHELL L.G. 1979: Myxosporida. In: J.F. Kreier (Ed.), Parasitic Protozoa. Vol. 4. Academic Press, New York, pp. 115154.

MOLNÁR K. 1979a: Gill sphaerosporosis in the common carp and grasscarp. Acta Vet. Hung. 27: 99-133.

MOLNÄR K. 1979b: Myxobolus pavlovskii (Akhmerov, 1954) (Myxosporidia) infection in the silver carp and bighead. Acta Vet. Acad. Sci. Hung. 27: 207-216.

MOLNÁR K. 1982: Biology and histopathology of Thelohanellus nikolskii Achmerov, 1955 (Myxosporea, Myxozoa), a protozoan parasite of the common carp (Cyprinus carpio). Z. Parasitenkd. 68: 269-277.

MOLNÁR K. 1992: Ceratomyxa hungarica n. sp. and Chloromyxum proterorhini (Myxozoa: Myxosporea) from the freshwater goby Proterorhinus marmoratus (Pallas). Syst. Parasitol. 22: $25-31$

MOLNÁR K. 2002: Site preferences of fish myxosporeans in the gill. Dis. Aquat. Org. 48: 197-207.

MOLNÁR K., El-MANSY A., SZÉKELY C., BASKA F. 1999a: Development of Myxobolus dispar (Myxosporea: Myxobolidae) in an oligochaete alternate host, Tubifex tubifex. Folia Parasitol. 46: 15-21.
MOLNÁR K., El-MANSY A., SZÉKELY C., BASKA F. 1999b: Experimental identification of the actinosporean stage of Sphaerospora renicola Dyková and Lom, 1982 (Myxosporea: Sphaerosporidae) in oligochaete alternate hosts. J. Fish Dis. 22: 143-153.

MOLNÁR K., FISCHER-SCHERL T., BASKA F., HOFFMANN R. 1989: Hofferellosis in goldfish Carassius auratus and gibel carp Carassius auratus gibelio. Dis. Aquat. Org. 7: 89-95.

MOLNÁR K., KOVACS-GAYER E. 1986a: Biology and histopathology of Thelohanellus hovorkai Akhmerov, 1960 (Myxosporea, Myxozoa), a protozoan parasite of the common carp (Cyprinus carpio). Acta Vet. Hung. 34: 67-72.

MOLNÁR K., KOVACS-GAYER E. 1986b: Experimental induction of Sphaerospora renicola (Myxosporea) infection in common carp (Cyprinus carpio) by transmission of SBprotozoans. J. Appl. Ichthyol. 2: 42-46.

MONCADA L.I., LOPEZ M.C., MURCIA M.I., NICHOLS S., LEON F., GUIO O.L., CORREDOR A. 2001: Myxobolus sp., another opportunistic parasite in immunosuppressed patients? J. Clin. Microbiol. 39: 1938-1940.

MONTEIRO A.S., OKAMURA B., HOLLAND P.W.H. 2002: Orphan worm finds a home: Buddenbrockia is a myxozoan. Mol. Biol. Evol. 19: 968-971.

MORAN J.D.W., WHITAKER D.J., KENT M.L. 1999a: A review of myxosporean genus Kudoa Meglitsch, 1947, and its impact on the international aquaculture industry and commercial fisheries. Aquaculture 172: 163-196.

MORAN J.D.W., WHITAKER D.J., KENT M.L. 1999b: Natural and laboratory transmission of the marine myxozoan parasite Kudoa thyrsites to Atlantic salmon. J. Aquat. Anim. Health 11: 110-115.

MORRIS D.J., ADAMS A., RICHARDS R.H. 2000: In situ hybridisation identifies the gill as a portal of entry for PKX (Phylum Myxozoa), the causative agent of proliferative kidney disease in salmonids. Parasitol. Res. 86: 950-956.

MORRIS D.J., MORRIS D.C., ADAMS A. 2002: Development and release of a malacosporean (Myxozoa) from Plumatella repens (Bryozoa: Phylactolaemata). Folia Parasitol. 49: 2534.

MOSER M., KENT M.L. 1994: Myxosporea. In: J.P. Kreier (Ed.), Parasitic Protozoa. Vol. 8. Academic Press, New York, pp. 265-318.

MÜLLER J. 1841: Über Psorospermien. Arch. Anat. Physiol. Wissensch. Med. 5: 477-496.

MULSOW K. 1911: Ein neuer Gehirnparasit des Karpfens. Allg. Fisch. Zeitschr. 36: 483-485.

MUTSCHMANN F. 2004: Pathologic changes in African hyperoliid frogs due to a myxosporidian infection with a new species of Hoferellus (Myxozoa). Dis. Aquat. Org. 60: 215-222.

NAIDENOVA N.N., ZAIKA V.E. 1969: Two new protozoan species from fish from Black Sea. Parazitologiya 3: 97-101. (In Russian with English summary.)

NAIDENOVA N.N., ZAIKA V.E. 1970: Three new genera of myxosporean parasites of fish from the Indian Ocean. Zool. Zh. 49: 451-454. (In Russian with English summary.)

NAVILLE A. 1930: Le cycle chromosomique d'une nouvelle Actinomyxidie: Guyenotia sphaerulosa n. g., n. sp. Quart. J. Miscrosc. Sci. 73: 545-575.

NICHOLAS W.L., JONES J.W. 1959: Henneguya tegidiensis sp. nov. (Myxosporidia) from the freshwater fish Coregonus clupeoides pennantii (the gwyniad). Parasitology 49: 1-5.

NIELSEN C.V., KØIE M., SZÉKELY C., BUCHMANN K. 2002: Comparative analysis of 18S rRNA genes from M. aeglefini Auerbach, 1906 isolated from cod, plaice and dab, using PCR-RFLP. Bull. Eur. Assoc. Fish Pathol. 22: 201-205. 
NOBLE E.R. 1939: Myxosporidia from tide pool fishes of California. J. Parasitol. 25: 359-364.

NOBLE E.R. 1950: On a myxosporidian (protozoan) parasite of California trout. J. Parasitol. 36: 457-460.

NOGA E.J. 1995: Fish Disease. Diagnosis and Treatment. Mosby, St. Louis, $367 \mathrm{pp}$.

NYLUND A., KARLSBAKK E., SATHER P.A., KOREN C., LARSEN T., NIELSEN B.D., BRODERUD A.E., HOSTLUND C., FJELLSOY K.R., LERVIK K., ROSNES L. 2005: Parvicapsula pseudobranchicola (Myxosporea) in farmed Atlantic salmon Salmo salar: tissue distribution, diagnosis and phylogeny. Dis. Aquat. Org. 63: 197-204.

ODENING K., WALTER G., BOCKHARDT I. 1988: Zur jahreszeitlichen Dynamik von Sphaerospora renicola (Myxosporidia) beim Karpfen (Osteichthyes). Angew. Parasitol. 29: $65-80$.

ODENING K., WALTER G., BOCKHARDT I. 1989: Zum Infektionsgeschehen bei Sphaerospora renicola (Myxosporidia). Angew. Parasitol. 30: 131-140.

OKAMURA B., ANDERSON C.L., LONGSHAW M., FEIST S.W., CANNING E.U. 2001: Patterns of occurrence and 18S rDNA sequence variation of PKX (Tetracapsula bryosalmonae), the causative agent of salmonid proliferative kidney disease. J. Parasitol. 87: 379-385.

OKAMURA B., CURRY A., WOOD T.S., CANNING E.U. 2002: Ultrastructure of Buddenbrockia identifies it as a myxozoan and verifies the bilaterian origin of the Myxozoa. Parasitology 124: 215-223.

OKAMURA B., WOOD T.S. 2002: Bryozoans as hosts for Tetracapsula bryosalmonae, the PKX organism. J. Fish Dis. 25: 469-475.

OVERSTREET R.M. 1976: Fabespora vermicola sp. n., the first myxosporidan from a platyhelminth. J. Parasitol. 62: 680684.

ÖZER A., WOOTTEN R.R. 2000: The life cycle of Sphaerospora truttae (Myxozoa: Myxosporea) and some features of the biology of both the actinosporean and myxosporean stages. Dis. Aquat. Org. 40: 33-39.

PADROS F., PALENZUELA O., HISPANO C., TOSAS O., ZARZA C., CRESPO S., ALVAREZ-PELLITERO P. 2001: Myxidium leei (Myxozoa) infections in aquarium reared Mediterranean fish species. Dis. Aquat. Org. 47: 57-62.

PALENZUELA O., ALVAREZ-PELLITERO P., SITJÀBOBADILLA A. 1997: Ceratomyxa sparusaurati (Protozoa: Myxosporea) infections in cultured gilthead bream Sparus aurata (Pisces: Teleostei) from Spain: aspects of the hostparasite relationship. Parasitol. Res. 83: 539-548.

PALENZUELA O., ALVAREZ-PELLITERO P., SITJÀBOBADILLA A. 1999: Glomerular disease associated with Polysporoplasma sparis (Myxozoa) infections in cultured gilthead sea bream, Sparus aurata L. Parasitology 118: 245256.

PALENZUELA O., REDONDO M.J., ALVAREZ-PELLITERO P. 2002: Description of Enteromyxum scophthalmi gen. nov., sp. nov. (Myxozoa), an intestinal parasite of turbot (Scophthalmus maximus L.) using morphological and ribosomal RNA sequence data. Parasitology 124: 369-379.

PARISI B. 1912: Primo contributo alla distribuzione geografica dei Missosporidi in Italia. Atti Soc. Ital. Sci. Nat. 50: 283 290

PATASHNIK M., GRONINGER H.S. Jr., BARNETT H., KUDO G., KOURY B. 1982: Pacific whiting, Merluccius productus; I. Abnormal muscle texture caused by myxosporidian-induced proteolysis. Mar. Fish Rev. 44: 1-12.
PÉRARD C. 1928: Sur une maladie du maquereau (Scomber scomber L.) due à une myxosporidie: Chloromyxum histolyticum n. sp. C. R. Acad. Sci. Paris 186: 108-110.

PINTO C. 1928: Myxosporideos e outros protozoarios intestinaes de peixes observados na America do Sul. Arch. Inst. Biol. 1: 101-131.

PLEHN M. 1905: Ueber die Drehkrankheit der Salmoniden (Lentospora cerebralis [Hofer] Plehn). Arch. Protistenkd. 5: $145-166$.

PLEHN M. 1924: Praktikum der Fischkrankheiten. Schweizerbart'sche Verlagsbuchhandlung, Stuttgart, VIII +179 pp.

PLEHN M. 1925: Eine neue Schleienkrankheit. Allgem. Fischerei-Ztg. (Neudamm) 28: 299-300.

POISSON R. 1953: Sous-Embranchement des Cnidosporidies. In: P.-P. Grassé (Ed.), Traité de Zoologie. Vol. 1, Fasc. II. Masson \& Cie, pp. 1006-1088.

POTE L.M., HANSON L.A., SHIVAJI R. 2000: Small subunit ribosomal RNA sequences link the cause of proliferative gill disease in channel catfish to Henneguya ictaluri (Myxozoa: Myxosporea). J. Aquat. Anim. Health 12: 230-240.

PRIEBE K. 1987: Disseminated degeneration of somatic musculature of a blue ling (Molva dypterygia) caused by a Trilospora species. Bull. Eur. Assoc. Fish Pathol. 7: 86-89.

QADRI S.S. 1962a: On a new myxosporidian parasite, Phlogospora mysti gen. n., sp. n., from Indian freshwater fish Mystus bleekeri. Arch. Protistenkd. 106: 211-217.

QADRI S.S. 1962b: New myxosporidia from Indian freshwater fish, Labeo fimbriatus. I. Gyrospora crucifila gen. n., sp. n. Z. Parasitenkd. 21: 513-516.

RÁCZ O.Z., ESZTERBAUER E., MOLNÁR K. 2005: Hungactinomyxon, a new actinosporean type and collective group (Myxozoa) from Branchiura sowerbyi Beddard (Oligochaeta). Syst. Parasitol. 61: 107-113.

REDONDO M.J., PALENZUELA O., ALVAREZ-PELLITERO P. 2004: Studies on transmission and life cycle of Enteromyxum scophthalmi (Myxozoa), an enteric parasite of turbot (Scophthalmus maximus L.). Folia Parasitol. 51: 188-198.

REIMSCHUESSEL R., GIESEKER C.M., DRISCOLL C., BAYA A., KANE A.S., BLAZER V.S., EVANS J.J., KENT M.L., MORAN J.D.W., POYNTON S.L. 2003: Myxosporean plasmodial infection associated with ulcerative lesions in young-of-the-year Atlantic menhaden in a tributary of the Chesapeake Bay, and possible links to Kudoa clupeidae. Dis. Aquat. Org. 53: 143-166.

REUSS H. 1906: Neue Myxosporidien von Süsswasserfischen. Bull. Acad. Imp. Sci. St.-Petersbourg 25: 199-205.

RHEE J.K., KIM J.O., KIM P.G., PARK B.K. 1990: Prophylactic and therapeutic studies on intestinal giant-cystic disease of the Israel carp caused by Thelohanellus kitauei. I. Course of formation and vanishment of the cysts. Kor. J. Parasitol. 28: 1183-1194.

RUIDISCH S., El-MATBOULI M., HOFFMANN R.W. 1991: The role of tubificid worms as an intermediate host in the life cycle of Myxobolus pavlovskii (Achmerov, 1954). Parasitol. Res. 77: 663-667.

SAKAGUCHI S., HARA T., MATSUSATO T., SHIBAHARA T., YAMAGATA Y., KAWAI H., MAENO Y. 1987: Scoliosis of cultured yellowtail caused by parasitic Myxobolus buri. Bull. Natl. Res. Inst. Aquaculture 12: 79-86. (In Japanese with English summary.)

SALIM K.Y., DESSER S.S. 2000: Descriptions and phylogenetic systematics of Myxobolus spp. from cyprinids in Algonquin Park, Ontario. J. Eukaryot. Microbiol. 47: 309-318.

SANKURATHRI C.S. 1977: Conispora renalis gen. nov. et $\mathrm{sp}$ nov. (Myxosporidia: Wardiidae) from the kidney tubules of 
Pacific hake Merlucius productus (Ayres, 1855), in coastal waters of British Columbia. Can. J. Zool. 55: 1147-1150.

SCHÄPERCLAUS W. 1992: Fish Diseases. Volumes 1 and 2. A.A. Balkema, Rotterdam, 1398 pp.

SCHLEGEL M., LOM J., STECHMANN A., BERNHARD D., LEIPE D., DYKOVÁ I., SOGIN M. 1996: Phylogenetic analysis of complete small subunit ribosomal RNA coding region of Myxidium lieberkuehni. Evidence that Myxozoa are Metazoa and related with Bilateria. Arch. Protistenkd. 147: 19

SCHRÖDER O. 1910: Buddenbrockia plumatellae, eine neue Mesozoenart aus Plumatella repens L. und Pl. fungosa Pall. Z. Wissenschaft. Zool. 96: 525-537.

SCHUBERG A., SCHRÖDER O. 1905: Myxosporidien aus dem Nervensystem und der Haut der Bachforelle (Myxobolus neurobius und Henneguya nüsslini). Arch. Protistenkd. 6: 61110 .

SCHUBERT G. 1968: Elektronenmikroskopische Untersuchungen zur Sporenentwicklung von Henneguya pinnae Schubert (Sporozoa, Myxosporidea, Myxobolidae). Z. Parasitenkd. 30: $57-77$.

SCHUBERT G., SPRAGUE V., REINBOTH R. 1975: Observations on a new species of Unicapsula (Myxosporida) in the fish Maena smaris (L.) by conventional and electron microscopy. Z. Parasitenkd. 46: 245-252.

SHUKGALTER O.A. 2004: The parasite fauna of the chub mackerel (Scombridae: Scomber japonicus Houtuym, 1782) in the Central-Eastern Atlantic (Atlantic coast of Northern Africa and the Azores archipelago banks). Parazitologiya 38: 160 168.

SHULMAN S.S. 1953: [New and little known myxosporidia of the White Sea.] Zool. Zh. 32: 385-393. (In Russian.)

SHULMAN S.S. 1959: [New system of myxosporidia.] Trudy Karelsk. fil. AN SSSR, 14, Voprosy parazitol. Karelii 33-47. (In Russian.)

SHULMAN S.S. 1962: Myxosporidia. In: E.N. Pavlovskii (Ed.), [Key to parasites of freshwater fish of USSR.]. Publ. House of the Academy of Sciences of the USSR, Moscow-Leningrad, pp. 47-130. (In Russian.)

SHULMAN S.S. 1966: [Myxosporidia of the USSR.] Nauka, Moscow-Leningrad, 504 pp. (In Russian; English translation 1988: Amerind Publ. Co. Pvt. Ltd., New Delhi, 631 pp.)

SHULMAN S.S. (Ed.) 1984: [Parasitic Protozoa.] Vol. 1. In: O.N Bauer (Ed.), [Key to the Parasites of Freshwater Fauna of USSR, Vol. 140 of the Keys to the Fauna of the USSR. Nauka, Leningrad, 428 pp. (In Russian.)

SHULMAN S.S., DONETS Z.S., KOVALEVA A.A. 1997: [Class Myxosporidia of the world fauna]. Vol. 1. Nauka, Sankt-Peterburg, 578 pp. (In Russian.)

SHULMAN S.S., KOVALEVA A.A., DUBINA V.R. 1979: New myxosporidians from fishes of the Atlantic coast of Africa. Parazitologiya 13: 71-79. (In Russian with English summary.)

SHULMAN S.S., SHULMAN-ALBOVA R.E. 1953: [Parasites of fish from the White Sea.] Izd. Akad. Nauk SSSR, Moscow, 198 pp. (In Russian.)

SIDDALL M.E., MARTIN D.S., BRIDGE D., DESSER S.S., CONE D.K. 1995: The demise of a phylum of protists: phylogeny of the Myxozoa and other parasitic Cnidaria. J. Parasitol. 81: 961-967.

SINDERMANN C.J. 1970: Principal Diseases of Marine Fishes and Shellfishes. Academic Press, New York, London, 369 pp.

SITJÀ-BOBADILLA A., ALVAREZ-PELLITERO P. 1990: Sphaerospora testicularis sp. nov. (Myxosporea: Sphaerosporidae) in wild and cultured sea bass, Dicentrarchus labrax
(L.), from the Spanish Mediterranean area. J. Fish Dis. 13: 193-203.

SITJÀ-BOBADILLA A., ALVAREZ-PELLITERO P. 1992: Light and electron microscopic description of Sphaerospora dicentrarchi $\mathrm{n}$. sp. (Myxosporea: Sphaerosporidae) from wild and cultured sea bass, Dicentrarchus labrax L. J. Protozool. 39: 273-281.

SITJÀ-BOBADILLA A., ALVAREZ-PELLITERO P. 1993a: Pathologic effects of Sphaerospora dicentrarchi SitjàBobadilla and Alvarez-Pellitero, 1992 and S. testicularis Sitjà-Bobadilla and Alvarez-Pellitero, 1990 (Myxosporea: Bivalvulida) parasitic in the Mediterranean sea bass Dicentrarchus labrax L. (Teleostei: Serranidae) and the cellmediated immune reaction: a light and electron microscopy study. Parasitol. Res. 79: 119-129.

SITJÀ-BOBADILLA A., ALVAREZ-PELLITERO P. 1993b: Zschokkella mugilis $\mathrm{n}$. sp. (Myxosporea: Bivalvulida) from mullets (Teleostei: Mugilidae) of Mediterranean waters: light and electron microscopic description. J. Eukaryot. Microbiol. 40: 755-764.

SITJÀ-BOBADILLA A., ALVAREZ-PELLITERO P. 1994: Revised classification and key species of the genus Sphaerospora Davies, 1917 (Protozoa, Myxosporea). Res. Rev. Parasitol. 54: 67-80.

SITJÀ-BOBADILLA A., ALVAREZ-PELLITERO P. 1995: Light and electron microscopic description of Polysporoplasma n. g. (Myxosporea: Bivalvulida), Polysporoplasma sparis n. sp. from Sparus aurata (L.), and Polysporoplasma mugilis n. sp. from Liza aurata L. Eur. J. Protistol. 31: 77-89.

SITJÀ-BOBADILLA A., PALENZUELA O., ALVAREZPELLITERO P. 1995: Ceratomyxa sparusaurati n. sp. (Myxosporea: Bivalvulida), a new parasite from cultured gilthead bream (Sparus aurata L.) (Teleostei: Sparidae): light and electron microscopic description. J. Eukaryot. Microbiol. 42: 529-539.

SMOTHERS J.F., von DOHLEN C.D., SMITHE L.H. Jr., SPALL R.D. 1994: Molecular evidence that the myxozoan protists are metazoans. Science 265: 1719-1721.

SOŁTYNSKA M. 1967: Myxosporidia of fishes from the Zegrze Lake. Acta Protozool. 4: 307-325.

STEHR C., WHITAKER D.J. 1986: Host-parasite interaction of the myxosporeans Kudoa paniformis Kabata and Whitaker, 1981 and Kudoa thyrsites (Gilchrist, 1924) in the muscle of Pacific whiting, Merlucius productus (Ayres): an ultrastructural study. J. Fish Dis. 9: 505-517.

St-HILAIRE S., BOICHUK M., BAARNES D., HIGGINS M., DEVLIN R., WITHLER R., KHATTRA J., JONES S., KIESER D. 2002: Epizootiology of Parvicapsula minibicornis in Fraser River sockeye salmon, Oncorhynchus nerka (Walbaum). J. Fish Dis. 25: 107-120.

ŠTOLC, A. 1899: Actinomyxidia, eine neue Gruppe der Mesozoa, der Myxosporidien verwandt. Abh. Böhm. Ges. Wissensch. 8: $1-12$.

SUNDARA RAJULU G., RADHA R.S.P. 1966: A myxosporidian parasite Symmetrula cochinealis gen. et sp. nov. from an invertebrate host, Dactylopius indicus (a cochineal bug). Ann. Mag. Nat. Hist., Ser. 13, 9: 167-171.

SVOBODOVÁ Z., GROCH L. 1986: Gill disease due to infection with Sphaerospora molnari. Bull. VÚRH Vodňany 22: 1317. (In Czech with English summary.)

SWEARER S.E., ROBERTSON D.R. 1999: Life history, pathology, and description of Kudoa ovivora n. sp. (Myxozoa, Myxosporea): an ovarian parasite of Caribbean labroid fishes. J. Parasitol. 85: 337-353.

SZÉKELY C., El-MANSY A., MOLNÁR K., BASKA F. 1998: Development of Thelohanellus hovorkai and Thelohanellus 
nikolskii (Myxosporea: Myxozoa) in oligochaete alternate hosts. Fish Pathol. 33: 107-114.

SZÉKELY C., MOLNÁR K., RÁCZ O. 2001: Complete developmental cycle of Myxobolus pseudodispar (Gorbunova) (Myxosporea: Myxobolidae). J. Fish Dis. 24: 461-468.

SZÉKELY C., RÁCZ O., MOLNÁR K., ESZTERBAUER E. 2002: Development of Myxobolus macrocapsularis (Myxosporea: Myxobolidae) in an oligochaete alternate hosts, Tubifex tubifex. Dis. Aquat. Org. 48: 117-123.

TATICCHI M.I., GUSTINELLI A., FIORAVANTI M.L., CAFFARA M., PIERONI G., PREARO M. 2004: Is the worm-like organism found in the statoblasts of Plumatella fungosa (Bryozoa, Phylactolaemata) the vermiform phase of Tetracapsuloides bryosalmonae (Myxozoa, Malacosporea) ? Ital. J. Zool. 71: 143-146.

THÉLOHAN P. 1892: Observations sur les myxosporidies et éssai de classification de ces organismes. Bull. Soc. Philom. 4: $165-178$.

THÉLOHAN P. 1895: Recherches sur les Myxosporidies. Bull. Sci. Fr. Belg. 26: 100-394.

TOPS S., BAXA D.V., McDOWELL T.S., HEDRICK R.P., OKAMURA B. 2004: Evaluation of malacosporean life cycles through transmission studies. Dis. Aquat. Org. 60: 109121.

TOPS S., CURRY A., OKAMURA B. 2005: Diversity and systematics of myxozoans in the class Malacosporea. Invertebr. Biol. 124: 285-295.

TOPS S., OKAMURA B. 2003: Infection of bryozoans by Tetracapsuloides bryosalmonae at sites endemic for salmonid proliferative kidney disease. Dis. Aquat. Org. 57: 221-226.

TRIPATHI Y.R. 1948: Some new myxosporidia from Plymouth with a proposed new classification of the order. Parasitology 39: $110-118$.

TRIPATHI Y.R. 1953: Studies on parasites of Indian fishes I. Protozoa Myxosporidia together with a check list of parasitic protozoa described from Indian fishes. Rec. Indian Mus. (Calcutta) 50: 63-88.

TROUILLIER A., El-MATBOULI M., HOFFMANN R.W. 1996: A new look at the life cycle of Hoferellus carassii in the goldfish (Carassius auratus auratus) and its relation to "kidney enlargement disease" (KED). Folia Parasitol. 43: 173-187.

TUN T., OGAWA K., WAKABAYASHI H. 2002: Pathological changes induced by three myxosporeans in the intestine of cultured tiger puffer, Takifugu rubripes. J. Fish Dis. 25: 6372.

TUZET O., ORMIÈRES R. 1957: Ceratomyxa anguillae n. sp. Myxosporidie parasite de la vésicule biliaire des anguilles de l'étang de Thau. Ann. Parasitol. Hum. Comp. 32: 189-196.

URAWA S. 1994: Life cycle of Myxobolus arcticus, a myxosporean parasite of salmonid fishes. Proc. Int. Symp. Aquat. Anim. Health, Seattle 4-8. Sept. 1994, W-10.3.

USPENSKAYA A.V. 1984: [Cytology of Myxosporea.] Nauka Publ. House, Leningrad, 112 pp. (In Russian.)

USPENSKAYA A.V. 1995: Alternation of actinosporean and myxosporean phases in the life cycle of Zschokkella nova (Myxozoa). J. Eukaryot. Microbiol. 42: 665-668.

VOSSBRINCK C.R., DEBRUNNER-VOSSBRINCK B.A. 2005: Molecular phylogeny of the Microsporidia: ecological, ultrastructural and taxonomic considerations. Folia Parasitol. 52: $131-142$.

WARD H.B. 1919: Notes on North American myxosporidia. J. Parasitol. 6: 49-64.

WEIDNER E., OVERSTREET R.M. 1979: Sporogenesis of a myxosporidian with motile spores. Cell Tissue Res. 201: 331342.
WHIPPS C.M., ADLARD R.D., BRYANT M.S., KENT M.L. 2003: Two unusual myxozoans, Kudoa quadricornis n. sp. (Multivalvulida) from the muscle of goldspotted trevally $\mathrm{C} \mathrm{Ca}$ rangoides fulvoguttatus) and Kudoa permulticapsulata n. $\mathrm{sp}$. (Multivalvulida) from the muscle of Spanish mackerel (Scomberomorus commerson) from the Great Barrier Reef, Australia. J. Parasitol. 89: 168-173.

WHIPPS C.M., GROSSEL G., ADLARD R.D., YOKOYAMA H., BRYANT M.S., MUNDAY B.L., KENT M.L. 2004: Phylogeny of the Multivalvulidae (Myxozoa: Myxosporea) based on comparative ribosomal DNA sequence analysis. J. Parasitol. 90: 618-622.

WHITAKER D.J., KENT M.L. 1991: Myxosporean Kudoa thyrsites (Myxosporea) a cause of soft flesh in farm-reared Atlantic salmon. J. Aquat. Anim. Health 3: 291-294.

WIERZBICKA J. 1986: Paramyxoproteus reinhardti gen. n. et sp. n. (Bivalvulidea, Myxospora) a parasite of Reinhardtius hippoglossoides (Walbaum, 1792). Acta Protozool. 25: 227-234.

WOLF K., MARKIW M.E. 1984: Biology contravenes taxonomy in the Myxozoa: new discoveries show alternation of invertebrate and vertebrate hosts. Science 255: 1449-1452.

WU B.H., WANG S.X., CHEN Y.S., LU C.C., HUANG L.F. 1979: On the pathogenic agent of the twist disease of the silver carp in Hangzhou region of the Jiang province. Acta Zool. Sin. 25: 60-68.

WU B.H., WANG S.X., JIANG N.C. 1988: A new species Tetrauronema macropodus sp. nov. (gen. et fam. nov.) from freshwater fishes of China. Acta Zootaxon. Sin. 13: 315-316.

WYATT E.J. 1978: Studies on the epizootiology of Myxobolus insidiosus Wyatt and Pratt (Protozoa, Myxosporidia). J. Fish Dis. 1: 233-240.

WYATT E.J. 1979: Facieplatycauda pratti gen. n., sp. n. and two new species of Myxobolus (Myxosporida). J. Protozool. 26: $47-51$.

WYATT E.J., PRATT I. 1963: Myxobolus insidiosus sp. n. a myxosporidian from the musculature of Oncorhynchus tshawytscha (Walbaum). J. Parasitol. 49: 951-955.

XIAO C., DESSER S.S. 2000: Cladistic analysis of myxozoan species with known alternating life-cycles. Syst. Parasitol. 46: $81-91$

XIE X.R., CHEN Q.L. 1988: A new genus and species of family Tetracapsulidae from marine fishes in South China Sea (Myxosporea: Multivalvulida). Oceanol. Limnol. Sin. 19: 431-434.

YANAGIDA T., NOMURA Y., KIMURA T., FUKUDA Y., YOKOYAMA H., OGAWA K. 2004: Molecular and morphological redescriptions of enteric myxozoans, Enteromyxum leei (formerly Myxidium sp. TFI) and Enteromyxum fugu comb. n. (syn. Myxidium fugu) from cultured tiger puffer. Fish Pathol. 39: 137-143.

YASUDA H., OOYAMA T., IWATA K., TUN T., YOKOYAMA H., OGAWA K. 2002: Fish-to-fish transmission of Myxidium spp. (Myxozoa) in cultured tiger puffer suffering from emaciation disease. Fish Pathol. 37: 29-33.

YASUTAKE W.T., ELLIOT D.G. 2003: Epizootiology and histopathology of Parvicapsula sp. in coho salmon Oncorhynchus kisutch. Dis. Aquat. Org. 56: 215-221.

YOKOYAMA H. 1997: Transmission of Thelohanellus hovorkai Achmerov, 1960 (Myxosporea: Myxozoa) to common carp, Cyprinus carpio, through the alternate oligochaete host. Syst. Parasitol. 36: 79-84.

YOKOYAMA H., FREEMAN M.A., YOSHINAGA T., OGAWA K. 2004: Myxobolus buri, the myxosporean parasite causing scoliosis of yellowtail, is synonymous with Myxobolus acanthogobii infecting the brain of the yellowfin goby. Fish. Sci. 70: 1036-1042. 
YOKOYAMA H., ITOH N. 2005: Two multivalvulid myxozoans causing postmortem myoliquefaction: Kudoa megacapsula $\mathrm{n}$. sp. from red barracuda (Sphyraena pinguis) and Kudoa thyrsites from splendid alfonso (Beryx splendens). J. Parasitol. 91: 1132-1137.

YOKOYAMA H., ITOH N., TANAKA S. 2005: Henneguya pagri n. sp. (Myxozoa: Myxosporea) causing cardiac henneguyosis in red sea bream, Pagrus major (Temminck \& Schlegel). J. Fish Dis. 28: 479-487.

YOKOYAMA H., KAWAKAMI H., YASUDA H., TANAKA S. 2003: Henneguya lateolabracis sp. n. (Myxozoa: Myxosporea), the causative agent of cardiac henneguyosis in Chinese sea bass Lateolabrax sp. Fish. Sci. 69: 1116-1120.

YOKOYAMA H., LIYANAGE Y.S., SUGAI A., WAKABAYASHI H. 1998: Hemorrhagic thelohanellosis of color carp caused by Thelohanellus hovorkai (Myxozoa: Myxosporea). Fish Pathol. 33: 85-89.

YOKOYAMA H., MASUDA K. 2001: Kudoa sp. (Myxozoa) causing a post-mortem myoliquefaction of North-Pacific octopus Paroctopus dofleini (Cephalopoda: Octopodidae). Bull. Eur. Assoc. Fish Pathol. 21: 266-268.

YOKOYAMA H., OGAWA K., WAKABAYASHI H. 1991: A new collection method of actinosporeans - a probable infec-

Received 24 November 2005 tive stage of myxosporeans to fishes - from tubificids and experimental infection of goldfish with the actinosporean, Raabeia sp. Gyobyo Kenkyu 26: 133-138. (In Japanese with English summary.)

YOKOYAMA H., OGAWA K., WAKABAYASHI H. 1993: Involvement of Branchiura sowerbyi (Oligochaeta: Annelida) in the transmission of Hoferellus carassii (Myxosporea: Myxozoa), the causative agent of kidney enlargement disease (KDE) of goldfish Carassius auratus. Gyobyo Kenkyu 28: 135-139.

YOKOYAMA H., OGAWA K., WAKABAYASHI H. 1995: Myxobolus cultus n. sp. (Myxosporea: Myxobolidae) in the goldfish Carassius auratus transformed from the actinosporean stage in the oligochaete Branchiura sowerbyi. J. Parasitol. 81: 446-451.

YOSHINO T.P., MOSER M. 1974: Myxosporida (Protozoa) in macrourid fishes (Coryphaeonoides spp.) in the Northeastern Pacific. J. Parasitol. 60: 655-659.

ZRZAVÝ J., HYPŠA V. 2003: Myxozoa, Polypodium, and the origin of the Bilateria: the phylogenetic position of "Endocnidozoa" in light of the rediscovery of Buddenbrockia. Cladistics 19: 164-169.

Accepted 3 February 2006 